P. Cuccuini, C. Nepi, M. N. Abuhadra, E. Banfi, G. Domina, E. Luccioli, S. Miranda, K. Pagitz, M. Thiv \& E. Vela

\title{
The Libyan Collections in FI (Herbarium Centrale Italicum and Webb Herbarium) and Studies on the Libyan Flora by R. Pampanini - Part 2
}

\author{
-The original material of new taxa conserved in the herbarium \\ -Proposals for typification and documentation of typifications already made \\ (Phanerogams, families from $N$ to $Z$ ) \\ -Conclusions \\ -Addenda \& Corrigenda
}

\begin{abstract}
Cuccuini, P., Nepi, C., Abuhadra, M. N., Banfi, E., Domina, G., Luccioli, E., Miranda, S., Pagitz, K., Thiv, M. \& Vela, E.: The Libyan Collections in FI (Herbarium Centrale Italicum and Webb Herbarium) and Studies on the Libyan Flora by R. Pampanini - Part 2. - F1. Medit. 26: 81-143. 2016. - ISSN: 1120-4052 printed, 2240-4538 online.

This work is the continuation of Part 1, published in 2015, and comprises the reconstruction of the original collections of new taxa described by R. Pampanini and other botanists and, where possible, typification of the new names and taxonomical updating. The material studied for the most part concerns Libyan specimens held in the FI and FI-W herbaria but in some case also K, LD, MPU, P, PAD, PAL, ULT. Other material, which Pampanini studied in Florence was subsequently conserved in other herbaria. Specimens belonging to 21 families have been examined, from the Najadaceae to Zygophyllaceae. As well as typification, bibliographical data have been provided for those already typified. In this second part, a total of 113 names have been indexed and 91 typified, taking the names validly published in the entire work to 353, of which 286 are typified. Also on this occasion, we have provided taxonomic updates for each taxon. The Conclusions present a synthetic sum of the taxa still recognised taxonomically (entirely, in new combinations, or with a new status) in recent works on the Flora of N. Africa, in general revisions of various systematic groups, or reconsidered by the authors of this present work. We have also investigated the phyto-geographic origins of the taxa [according to the dominions proposed by Quézel (1978) for N. Africa]. Finally we have very briefly indicated the presence of material of the R. Pampanini collections (for Cyrenaica, together with R. E. G. Pichi Sermolli in 1934) in the most important herbaria.

The paragraph "Addenda et Corrigenda" has been added to the final part of the treatise and relates chiefly to taxa omitted from the first part, either on account of new information or as a result of errors which came to light after publication.
\end{abstract}

Key words: museology, nomenclature, taxonomy, typification, Flora of Libya, N. Africa, phytogeography, Addenda \& Corrigenda. 


\section{Introduction}

The second part of the work on Libyan collections kept or studied at FI herbarium is the continuation of Cuccuini \& al. (2015).

It starts with Najadaceae and ends with Zygophyllaceae family. The methods used are the same as the first part. At the end of the work, in addition to the conclusions, the coordinators have added a paragraph of 'Addenda et Corrigenda' that, as far as possible, recovers materials not previously found or corrects inaccuracies and errors in the first part.

\section{CATALOGUE}

Continuation from Cuccuini \& al. (2015). For the legend of format, see Cuccuini \& al. (2015). As compared with the first part, several new authors of taxa and collectors are included here. Among the former are A. Engler, P. Pavone, S. Pignatti, H. Scholz and D. Viviani, and among the second, Della Cella (as collector of the material represented in two tables by D. Viviani), A. Figari Bey, and G. A. A. Krause (the last included in the list of collectors but non mentioned in the text of the first part).

\section{Najadaceae (S. Miranda)}

New taxon: Najas minor var. longifolia Corti in Flora e Vegetazione del Fezzan e della Regione di Gat. Reale Società Geografica Italiana 1: 30. (1942).

Typus: [Libya], Fezzan occidentale: reg. di Gat, Elbarcat, 700 m., (1180), fossetto emissario della sorgente grande, abbondantissima, 02/03/1934. Leg. R. Corti. (FI016321, Lectotypus designated here).

Other Syntypi from the original collection: (1181-1186) (FI016322-FI016327).

Accepted name: Najas minor Allioni see: L. Triest in: Mém. Acad. Roy. Sci. Outre-Mer, Cl. Sci. Nat. Méd. Collect. 8vo n.s., 21: 59. 1987.

Note: also Jafri in: Fl. Lib.113: 2-4. 1984a; in Triest 1987: 59, there is the complete citation of the Type, but the author declares: "non vidi"; on the sheet of the lectotypus there is a small label with a handwritten note (no. 000292) in pencil by Corti.

\section{Oleaceae (G. Domina)}

New taxon: Phillyrea latifolia var. magnifica Pamp. in Arch. Bot. XII(1): 40. (1936a); Rend. Sem. Fac. Sc. Univ. Cagliari VIII(3): 73. (1938).

Type: Libya, Cirenaica, fra el Hania e Messa: 1.d. Mregheb (6093), 09/05/1934. Leg. R. Pampanini \& R.E.G. Pichi Sermolli, (FI001160, Lectotypus designated here).

Accepted name: Phillyrea latifolia L.

Note: the specimen no. 6093 is made up of two sheets mounted together clearly belonging to the same collection. In the first there is a piece of newspaper with the new name of the taxon handwritten by Pampanini.

\section{Orobanchaceae (G. Domina \& M. Abuhadra)}

New taxon: Cistanche lutea f. pallida Pamp. in Arch. Bot. XII(1): 43. (1936a). Rend. Sem. Fac. Sc. Univ. Cagliari VIII(3): 75. (1938). 
Type: Libia, Cirenaica: Tra Bir Acheim e el-Mechili, Trigh Enver Bei Bir Bu Usceica (7355), 26/03/1933, Leg. R. Pampanini, (FI003688, Lectotypus designated here).

Other syntypus from the original collection: C.: el-Mechili, Uadi Ramla (7356), 27/03/1933, Leg. R. Pampanini (FI003689).

Accepted name: Cistanche phelypaea (L.) Cout.

Note: the specimen 7355 is accompanied by a strip of newspaper with the name of the new taxon handwritten by Pampanini; specimen 7356 is made up of three sheets.

New taxon: Cistanche violacea f. bicolor Pamp. in: Arch. Bot. XII(1): 43. (1936a); Rend. Sem. Fac. Sc. Univ. Cagliari VIII(3): 75. (1938).

Type: Libia, Cirenaica: Msus (7365), 20/03/1933, Leg. R. Pampanini (FI003690) (Lectotypus designated here).

Other syntypi from the original collection: C: Steppa di el-Agheila (7363), 14/03/1933, Leg. R. Pampanini (FI003691); C.: esc-Sceleidima, a sud-est di Bengasi (7364), 20/03/1933, Leg. R. Pampanini (FI003692); C.: Zuetina, a nord-est di Agedabia (7366), 11/03/1934, Leg. R. Pampanini \& R.E.G. Pichi Sermolli (FI003693).

Accepted name: Cistanche violacea (Desf.) G. Beck in Hoffmanns \& Link.

Note: the specimen no. 7363 is accompanied by a strip of newspaper with the name of the new taxon handwritten by Pampanini; the specimen no. 7365 is made up of three sheets.

\section{Papaveraceae (P. Cuccuini \& C. Nepi)}

The genus Hypecoum was considered by Jafri in Fl. Lib. 44. (1977b) as belonging to the family of the same name (Hypecoaceae). The present publication does not recognise this choice (under the same criterion, the genus could be placed in the Fumariaceae) and the genus is maintained in the Papaveraceae.

New taxon: Hypecoum aequilobum Viv. in Fl. Lib., specimen: 7-8, tab. III, fig. 3. (1824). Typus (Lectotypus): Fl. Lib., specimen, 1824, "H. in Cirenaica", tab. III, fig. 3. (Typified by Jafri S.M. H. (as typus) in Fl. Lib. 44: 5. 1977). (Fig. 1).

Epitypus: Libia, Cirenaica: tra Agedabia e Antelat a Bag Lia (2802), 10/04/1934. Leg. R. Pampanini \& R.E.G. Pichi Sermolli (FI).

Accepted name: Hypecoum aequilobum Viv.

Other material: Libia, Cirenaica: El Grein presso Marsa el Brega (2801), 08/04/1934. Leg. Pampanini \& R.E.G. Pichi Sermolli (FI).

Note: the Epitypus is under Hypecoum aequilobum Viv. var. stenolobum Pamp. [an invalid name since Pampanini 1936: 26, recorded it as “...Nomen novum, H. aequilobum Viv. Fl. Libyc. Specim. p. 7, tab. 3.1824 (sensu stricto)", thereby indicating the autonym of $H$. aequilobum (H. aequilobum var. aequilobum). Given that the original collection, kept in GE, cannot be located (S. Peccenini in litteris 2016), the typus is represented by the only surviving element of original material: table 3, fig. 3, details e, f, g, h of Viviani, Fl. Libyc. Specim. Since the Lectotypus could be ambiguous, we designate also as Epitypus the specimen R. Pampanini \& R.E.G. Pichi Sermolli 2802.

New taxon: Hypecoum aequilobum var. platylobum Pamp. in Arch. Bot. XII(1): 26. (1936a); Prodr. Fl. Cir. p.: 209 (sub H. aequilobum p.p.: specim. Zanon, Maugini). 1930. 


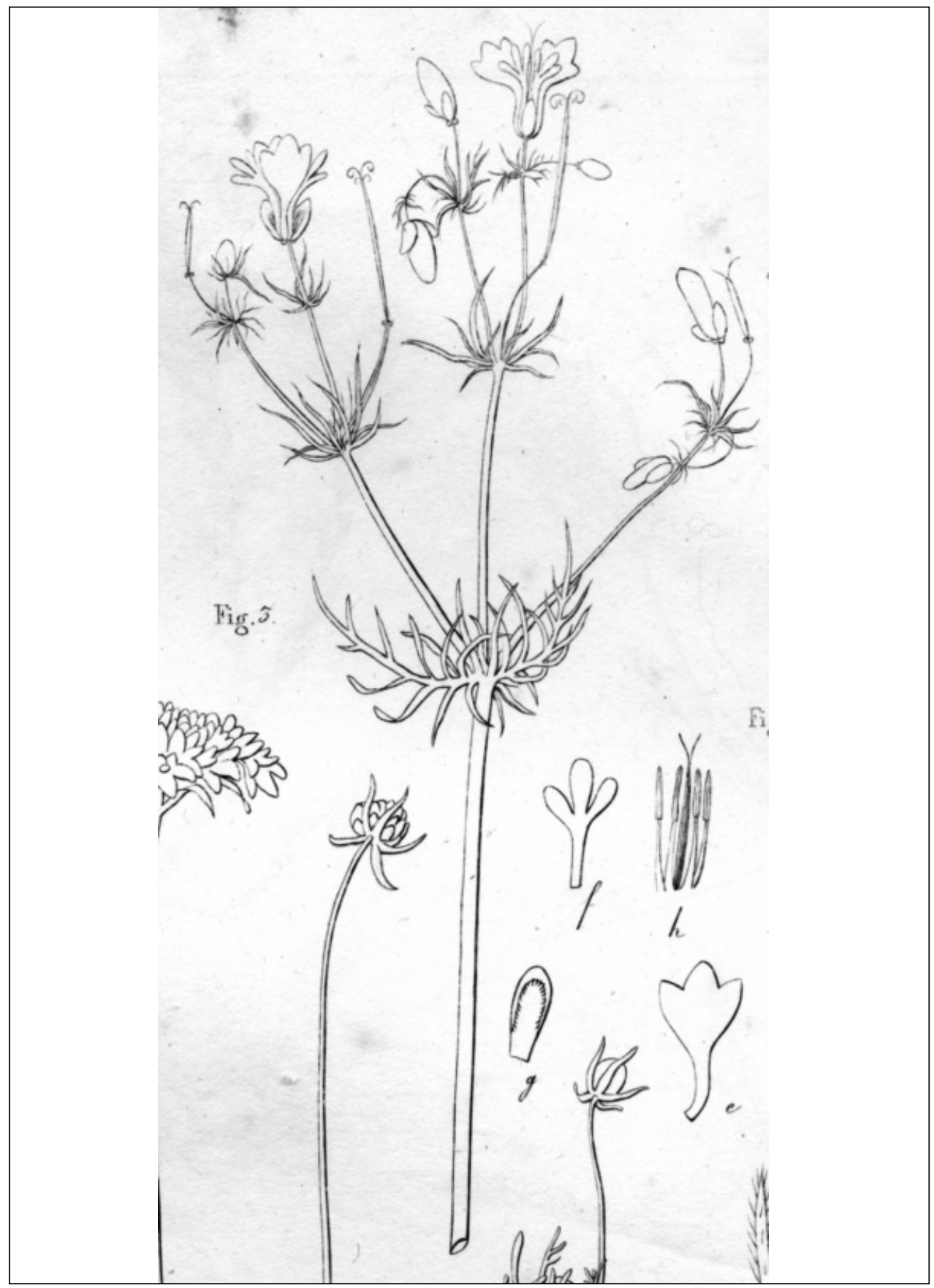

Fig. 1. Hypecoum aequilobum Viviani, Figure 3, details e, f, g, h of table III, published in Florae Libycae specimen, 1824, Lectotypus, kept in the library of Centro Studi Erbario Tropicale of Florence. 
Type: [Libya], Cirenaica, Bengasi: Palmeto (Monastir), 06/03/1922. Leg. A. Maugini, (FI003911, Lectotypus designated here).

Other syntypi from the original collection: [Libya], Cirenaica, Bengasi: Gariunes, (623), 26/04, FI003912; Be.: Punta Giuliana (579[3]), 21/03/1916, FI003913. Leg. V. Zanon. Be.: Palmeto, primavera 1921, FI003910; Be.: fra Selmani e Suani Osman, 12/02/1922, FI003908; Be.: Hauari, 02/ 1922, FI003909. Leg. A. Margini. (All in FI).

Accepted name: Hypecoum aequilobum Viv. s.l.

Note: the collection assembled by Pampanini in 1933-34, which was not mentioned in the pubblication by Pampanini (1938), even though it was part of the original collection, is composed of the following specimens: Cirenaica: Tra Agedabia e el Agheila, Melch en Nogra (2797), 15/03/1933. Leg. R. Pampanini. C.: Tra Agedabia e Antelat a Bag Lia (2798), 10/04; C.: el Gioch tra Agedabia e Saumnu (2799), 10/04.; C.: ez Zuetina a nord est di Agedabia (2800), 11/04/1934. Leg. R. Pampanini \& R.E.G. Pichi Sermolli, (all material in FI).

New taxon: Hypecoum pendulum var. zoddae Pamp. in Arch. Bot. VIII: 111. (1932).

Type: Holotypus: [Libya], Tripolitania, Garian: In cultis, Garian, 700 m., 24/3/1931. Leg. G. Zodda, (FI)

Accepted name: Hypecoum pendulum L. s.1.

Note: the material cited is not present in FI under this name, but sub. H. pendulum L. var. paradoxum Pamp. (a nomen nudum) with the same data handwritten by Pampanini himself. Initially, Pampanini probably decided on the first name and only later preferred the second in honour of Zodda, but did not leave any written notes to this effect. There is no doubt that this is the same taxon, seeing that the description in the protologue also corresponds perfectly even though the lack of flowers has complicated identification.

New taxon: Papaver rhoeas var. trichocarpum Pamp. in Bull. Soc. Bot. Ital. (1-3): 13. (1914a); Pl. Tripol.: 115. (1914e).

Type: Holotypus: [Libya], Tripolitania, Tarhuna: Uadi Tersiva, pianura a S.W. di Ras Maader (2082), 01/04/1913. Leg. R. Pampanini, (FI).

Accepted name: Papaver rhoeas L., see Dobignard \& Chatelain 5: 53. 2013.

Note: this name does not appear among those mentioned by Kadereit J.W. 1988.

New taxon: Roemeria hybrida f. latiloba Pamp. in Bull. Soc. Bot. Ital. (1-3): 13. (1914a); Pl. Tripol.: 116. (1914e).

Type: [Libya], Tripolitania, Tarhuna.: Ras Bu Tauil (4463), 21/03/1913. Leg. R. Pampanini. (FI, Lectotypus designated here).

Other syntypi from the original collection: [Libya], Tripolitania, Tarhuna: Abiar Milgha (412), 28/02; T., Ta.: Uadi Msaaba a Kars Doga (867), 18/03; T., Ta.: Ras Ghenai (1557), 25/05; T., Garian: Ras Bu Ganus (3937), 27/04/1913. Leg. R. Pampanini. (All syntipi in FI).

Accepted name: Roemeria hybrida (L.) DC. subsp. hybrida, see Dobignard \& Chatelain 5: 56. 2013.

Note: this last work improperly considers Roemeria hybrida (L.) DC. var. hybrida which, however, Pampanini never established. The authors probably found and took this error from the Flora of Libya, Jafri (1977b) or from Flora dell'Afrique du nord (1964). 
New taxon: Roemeria tenuifolia Pamp. in Nuovo Giorn. Bot. Ital. n.s. 26: 211-12. (1919).

Type: [Libya], Cirenaica: Fuehat (79), marzo 1918. Leg. V. Zanon (FI, Lectotypus designated here)

Other syntypi from the original collection: Egitto, Regione mediterranea, molto comune nei coltivi dell'antica marea verso Alessandria, anche nel deserto di Ramle di Abukir, dell'Istmo di Suez, del Sinai, Marzo e Aprile 1867. Leg. Figari Bey (FI).

Accepted name: Roemeria hybrida (L.) DC. subsp. hybrida, see Dobignard \& Chatelain 5: 56. 2013; also in Le Floc'h \& al. (2010).

Note: in Fl. Lib. 40: 8. 1977 Roemeria tenuifolia Pamp. = Roemeria hybrida (L.) DC. var. hybrida. Although Jafri (Jafri 1977b) considers it a synomyn, he points out the main distinguishing characters : " ... has almost glabrous fruits $(2.5-4 \mathrm{~cm}$ long) on robust thickened pedicels up to $7 \mathrm{~cm}$ long", but does not consider them sufficient for recognising a new taxon.

For Boulos, as comb. e stat nov. R. hybrida DC. var. tenuifolia (Pamp.) Boulos, in Candollea 34(1): 37. 1979; moreover, in 1933, Pampanini declared a comb. et status nov. for this taxon: Roemeria hybrida DC. var. tenuifolia (Pamp.) Pamp. (on the FI herbarium card). He never published it as such, but as $R$. hybrida DC. f. tenuifolia (Pamp.) Pamp., Pampanini (1936a).

\section{Plantaginaceae (P. Cuccuini \& C. Nepi)}

New taxon: Plantago albicans var. augustifolia f. syrtica Pamp. in Arch. Bot. XII(1): 43. (1936a); Rend. Sem. Fac. Sc. Univ. Cagliari VIII(3) 75. (1938).

Type: Holotypus: Libia, Cirenaica: fra Agheila e Maaten Giofer (7451), 15/03/1933. Leg. R. Pampanini, (FI003820).

Accepted name: Plantago albicans L.

New taxon: Plantago albicans var. desertica Pamp. in Agric. Colon., 10: 365. (1928).

Type: [Libya], Cirenaica: Fra l'Uadi Faregh e Maatan Risam, 18/04/1928. leg. G. Krüger, (FI003824, Lectotypus designate here).

Isolectotypi: (FI003821, FI003822, FI003823).

Accepted name: Plantago albicans L, see Siddichi M. A. in: Fl Lib.: 67: 21-22. 1979; also Dobignard \& Chatelain 5: 101. 2013.

Note: two of the 4 specimens mentioned above carry labels signed by Pampanini as well as the original ones, handwritten and signed by Krueger (FI003823, FI003824).

New taxon: Plantago albicans var. lanata Pamp. in Bull. Soc. Bot. Ital.: 18. (1914a); Pl. Tripol.: 226. (1914e).

Type: Holotypus: [Libya]: Tripolitania, Tarhuna: Pianura dell'Uadi Ksea (2405), 07/04/1913. Leg. R. Pampanini, (FI003825).

Accepted name: Plantago albicans L.

Note: although modern, even recent, Floras, indices and nomenclatural catalogues carry descriptions that include many previously described varieties under the same species, the presence of such different entities in similar habitats suggests the need for an indepth investigation over the territory. 
New taxon: Plantago albicans var. macropoda Pamp. in Bull. Soc. Bot. Ital. (1-3): 18. (1914a); Pl. Tripol. p.: 226. (1914e).

Type: Holotypus: [Libya], Tripolitania, Tripoli: Uadi Megenin presso Ain Zara (3508), 22/04/1913. Leg. R. Pampanini, (FI003826).

Accepted name: Plantago albicans L.

New taxon: Plantago coronopus var. commutata f. pubescens Pamp. in Arch. Bot. XII(1): 44. (1936a); Rend. Sem. Fac. Sc. Univ. Cagliari VIII(3): 76. (1938).

Type: Libia, Cirenaica: Sidi Ahmed el Magrun, a sud di Bengasi (7500), 17/03/1933. Leg. R. Pampanini, (FI003830, Lectotypus designated here).

Other syntypi from the original collection: Cirenaica: Msus (7501), 20/03, (FI003907); C., Mechili : Uadi Ramla (7502), 27/03/1933. Leg. R. Pampanini, (FI003827).

Accepted name: Plantago weldenii Rchb. s.l.

Note: specimen 7500 carries a piece of newspaper with the name of the new taxon handwritten in blue pencil by Pampanini.

New taxon: Plantago coronopus var. commutata f. villosa Pamp. in: Arch. Bot. XII(1): 44. (1936a); Rend. Sem. Fac. Sc. Univ. Cagliari VIII(3): 76. (1938).

Type: Libia, Cirenaica: fra Derna e Mechili: Uadi el Hescia (7505), 10/4/1933. Leg. R. Pampanini, (FI003829, Lectotypus designated here).

Other syntypi from the original collection: Libia, Cirenaica: Agheila, giardini (7504), 15/03, (FI003828); C.: fra Sidi Frag e el Magrun a nord di Agedabia (7503), 11/03/1933, Leg. R. Pampanini, (FI003934); (all material in FI).

Accepted name: this material is an intermediate form between $P$. crypsoides Boiss. and $P$. weldenii Rchb., probably close to P. weldenii Rchb., sensu Dobignard \& Chatelain (2013).

Note: the label for no. 7503 (FI003934) does not indicate “... e El Magrun”, moreover a piece of newspaper on the specimen carries the name of the new taxon handwritten in blue pencil by Pampanini.

\section{Plumbaginaceae (G. Domina)}

New taxon: Limonium bonduellei f. gigantifolia Corti in Flora e Vegetazione del Fezzan e della Regione di Gat. Reale Società Geografica Italiana 1: 1-203. 1942.

Type: [Libya], Fezzan Settentrionale, sul Gargáf a nord di Brach, (1233), 14/02/1934, Leg. R. Corti (FI003575, Lectotypus designated here).

Other syntypi from the original collection: Fezzan occidentale, valico tra Elbárcat e l'U. Iséien- nell'Uadi in roccia, verso Elbárcat (1231), 13/03/1934. Leg. R. Corti.

Accepted name: Limonium bonduellei (Lestib.) O. Kuntze.

Note: the syntypus: Fezzan occidentale, valico tra Elbárcat e l'U. Iséien- nell'Uadi in roccia, verso Elbárcat (1231), 13/03/1934. Leg. R. Corti, cited in the original publication, was not found in FI.

New taxon: Limonium teuchirae Brullo in Webbia 33(1): 148. 1978.

Type: Holotypus (CAT12956) [Libya, Cyrenaica], Sebchet el Cuz (Bengasi), 15/09/1974. Leg. S. Brullo \& F. Furnari. (by Brullo in Webbia 33(1): 148. 1978). 
Isotypi: (CAT12957-CAT12957-13), (FI003916).

Accepted name: Limonium teuchirae Brullo.

New taxon: Limonium vaccarii Pignatti ex Brullo in Webbia 33(1): 148. 1978.

Type: Holotypus: [Cyrenaica]: Tobruk, 23/05/1912 (147). Leg. A. Vaccari (PAD). Isotypes in FI and in PAL.

Accepted name: Limonium vaccarii Pignatti ex Brullo.

Note: taxon described for the first time with the illegitimate name of Statice delicatula Béguinot \& Vaccari (1912), non Girard. (1844). Pignatti (1963) published it as Limonium sibthorpianum subsp. vaccarii, but without a description (nomem nudum). Finally the taxon was re-described by Brullo (1978) who attributed the name to Pignatti. In FI, an isotype is probably lost.

New taxon: Statice delicatula var. subrotundifolia Bèg. \& Vaccari in Sec. Contr. Fl. Lib.: 29. 1913.

Type: Lectotypus (designated by Brullo 1978: 146): Libia, Cirenaica, Derna in collibus aridis saxosis maritimis prope il faro, 21/10/1912, Leg. A. Vaccari, no. 148 Fl. Lyb. Exs. (PAD).

Isolectotypi: FI003576, PAD.

Accepted name: Limonium subrotundifolium (Bèg. \& Vaccari) Brullo in Webbia 33(1): 145. 1978.

Note: collecting data: Cirenaica: Derna presso il faro, (148), 31/10/1912 (in Bibl.) 21/10/1912 (on the label).

New taxon: Statice pruinosa var. hirtiflora Cavara \& Grande in Bull. Orto Bot. Univ. Napoli 9 (1): 49.1928.

Typus: [Libya, Cyrenaica]: Costoni aridi di Porto Bardia (Marmarica), 21 febb. 1924, Leg. F. Cavara \& L. Grande (FI, Lectotypus designated here).

Accepted name: Limonium pruinosum (L.) Chaz., Suppl. Dict. Jard. 2: 36.1790.

Note: the specimen includes also one handwritten label with the description of the plant and taxonomic notes.

New taxon: Statice tubiflora var. zanonii Pamp. in Nuovo Gior. Bot. Ital. n.s. 24:148. (1917).

Type: [Libya], Cirenaica: Bengasi, Giok, 20/04/1916 (611), leg. V. Zanon, (FI, Lectotypus designated here).

Accepted name: Limonium zanonii (Pamp.) Domina in Willdenowia 41(1): 131. 2011.

Note: Giok Kebir falls within the Bengasi municipality, the different dates on the exsiccatum label and in the original publication is, probably, a transcription mistake. In any case, not knowing if the other specimens have been lost, we, prudently, prefer to designate it as the lectotypus of the name.

\section{Poaceae (E. Banfi)}

New taxon: Aegilops bicornis var. anathera Eig in Bull. Soc. Bot. Genève sér. 2 (19): 325. 1928.

Type: Isolectotypus: [Libya], Cyrenaica: [Benghasi] Juliana, an den Saliner, 3/04/1883. 
Leg. Ruhmer s.n. (401) (by M.W. van Slageren, Wageningen Agric. Univ. Papers 94-7: 12, 145. 1994; formerly marked by von Slageren 06/1992 as Aegilops bicornis (Forssk.) Jaub. \& Spach. var. mutica [Asch.] Eig).

Accepted name: Triticum bicorne f. muticum Asch. in Mágyar Bot. Lapok 6: 10. 1902 (mistakenly reported as unranked in Tropicos). The synonymisation of Aegilops L. with Triticum L., phylogenetically suitable (Petersen \& al. 2006; Sandve \& al. 2015) although so far put into practice by only a few authors, is accepted in the new editions of the Checklist of the Italian vascular Flora (Conti \& al. eds. in progress) and Flora d'Italia (Pignatti ed., in progress). Under Aegilops the legitimate name at variety rank (priority) seems to be Ae. bicornis var. mutica Post in F1. Syria: 901.1896 and such name is obviously based on a different type material (Haifa, Israel).

Note: this taxon is not more than a mere expression of the normal intrapopulational diversity of the species referring to the degree of development of awns (from complete to absent), especially in proximal and median spikelets.

New Taxon: Aristida obtusa f. arenosa Corti in Flora e Vegetazione del Fezzan e della Regione di Gat. Reale Società Geografica Italiana 1: 43. 1942.

Type: Holotypus: Fezzan Settentrionale, tra Bir el Ghelania e Brach, presso l'Uadi Issa, ca. 400 m. Leg. R. Corti (FI).

Accepted name: Stipagrostis obtusa (Delile) Nees.

Note: this form falls within the diversity pattern of the taxon described as Aristida foexiana Maire \& Wilczek in Bull. Soc. Hist. Nat. Afrique N. xxv: 322.1934 and also annotated in FI as Aristida obtusa var. pubescens Andreansky (?). In all cases it fits the normal range of variation of the species.

New taxon: Avena beguinotiana Pamp. in Arch. Bot. XII (2): 18. (1936a); Rend. Sem. Fac. Sc. Univ. Cagliari, 8 (3): 60. (1938).

Type: Libia, Cirenaica: Amseat a sud di Bardia (361), 24/03/1933. Leg. R. Pampanini (marked by B. Baum 1973) (FI, Lectotypus designated here).

Other material, Paralectotypi (marked as such by B. Baum 1973): Cirenaica, Sirte: Steppa di Agheila (360), 14/03/1933. Leg. R. Pampanini. C., Sirte: El Grein presso Marsa Brega (362), 8/04/1934; C.: Sahabi (Saniet el Hamar) a sud est di Agedabia (363), 9/04; C.: tra Agedabia e Antelat a Bag Lia (364), 10/04/1934. Leg. R. Pampanini \& R.E.G. Pichi Sermolli (all material in FI).

Accepted name: Avena ventricosa Balansa ex Cosson (Valdés \& Scholz 2009).

Note: Scholz H. in Willdenowia 7 (2): 420. 1974b refers to the type in FI but no other details are provided.

New taxon: Brachypodium distachyon var. genuinum f. mite Pamp. in Bull. Soc. Bot. Ital. (1-3): 11. (1914a); Pl. Tripol.: 13. (1914e).

Type: [Libya], Tripolitania, Garian: Bu Gheilan (4553), 24/04/ 1913. Leg. R. Pampanini (FI, Lectotypus designated here).

Other material, Syntypi: Tripolitania, Tarhuna: Uadi (Tersiva) Tenziua nelle steppe (1952), 1/04/1913; T., Mesellata: Cussabat sul Ras Gelà (4400), 13/04/1913. Leg. R. Pampanini, (all material in FI). 
Accepted name: Brachypodium distachyon (L.) P. Beauv.

Note: considered by authors till now as a synonym of $B$. distachyon.

New taxon: Brachypodium distachyon var. genuinum f. typicum subf. puberulum Pamp. in Arch. Bot. XII(1): 18. (1936a). Rend. Sem. Fac. Sc. Univ. Cagliari, VIII(3): 60. (1938).

Type: Libia, Cirenaica, Martuba, a sud est di Barce: Uadi el-Bgar (410), 8/04/1933. Leg. R. Pampanini, (FI, Lectotypus designated here).

Other material, Syntypi: Cirenaica, Mechili: Uadi Ramla (409), 27/03/1933; Cirenaica, Cirene: es Saf-Saf, Uadi Bu Meddas (411), 18/04/1933. Leg. R. Pampanini.

(Unpublished) Cirenaica, Cirene: Uadi Buten (412), 18/04/1933. Leg. R. Pampanini, (all material in FI).

Accepted name: Brachypodium distachyon (L.) P. Beauv.

Note: this taxon seems not to have been taken into account by systematic investigations and presumably it falls within the normal diversity range of the species.

New taxon: Brachypodium distachyon var. hispidum Pamp. in Bull. Soc. Bot. Ital. (1-3): 11. (1914a); Pl. Tripol.: 14. (1914c).

Type: [Libya], Tripolitania, Mesellata: Cussabat, Ras Gelà (3076), 13/04/1913. Leg. R. Pampanini, (FI, Lectotypus designated here).

Other material, Syntypi: Tripolitania, Garian: Bu Gheilan (3612), 24/04/1913; Tripolitania, Garian: Uadi Garian (3859), 26/04/1913. Leg. R. Pampanini.

(Unpublished) Tripolitania, Mesellata, Colline a N-W di Cussabat (2992), 12/04/1913. Leg. R. Pampanini, (all material in FI).

Accepted name: Brachypodium distachyon (L.) P. Beauv. var. hispidum Pamp. (Weiller M. in Maire R. \& Weiller M., Fl. Afrique N.: 280. 1955).

Note: separable from the nominal variety by glumes and lemmas hairy on entire surface.

New taxon: Brachypodium distachyon var. hispidum f. confusum Pamp. in Bull. Soc. Bot. Ital. 1914(5): 49. (1914b)

Accepted name: Brachypodium distachyon (L.) P. Beauv.

Note: in FI there is a sheet that bears following annotations: Cyrenaica, Uadi el-Kuf, fra Gasr Beni Gdam e Sidi Abd el Uahed (no. 413), 6/04/1933. Leg. R. Pampanini. It should be highlighted that the original material upon which Pampanini based his description of this taxon is not known.

New taxon: Brachypodium distachyon var. hispidum f. intermedium Pamp. in Bull. Soc. Bot. Ital. (1-3): 11. (1914a).; Pl. Tripol.: 14. (1914c).

Type: [Libya], Tripolitania, Tarhuna: Uadi Tersiva (Tenziua), Ras Maader (2044), 1/04/1913. Leg. R. Pampanini, (FI, Lectotypus designated here).

Other material, Syntypus: Tripolitania, Garian: Uadi Garian (4060), 29 aprile 1913. Leg. R. Pampanini.

Accepted name: Brachypodium distachyon (L.) P. Beauv. var. hispidum Pamp.

Note: it falls within the synonymy of var. hispidum despite Weiller M. in Maire R. \& Weiller M., Fl. Afrique N.: 281. 1955, treating it as a good form. Pampanini (1938) 
recombined later his taxon as $B$. distachyon $\mathrm{P}$. B. var. pubens Beck f. intermedium Pamp., however without providing explanations on the matter.

New taxon: Brachypodium distachyon var. hispidum f. pseudosubtile Pamp. in Bull. Soc. Bot. Ital. (1-3): 11. (1914a): 11; Pl. Tripol. p.: 14. (1914c).

Type: [Libya], Tripolitania, Tarhuna, Uadi Ksea, Ras Argobinani (2414), 8/04/1913. Leg. R. Pampanini, (FI, Lectotypus designated here).

Other material, Syntypus: Tripolitania, Tarhuna, Uadi Sart (1753), 27/03/1913. Leg. R. Pampanini, (FI).

Accepted name: Brachypodium distachyon (L.) P. Beauv.

Note: taken into consideration as a good taxon by Weiller M. in Maire R. \& Weiller M., Fl. Afrique N.: 280. 1955.

New taxon: Brachypodium distachyon var. velutinum Pamp. in Bull. Soc. Bot. Ital. (1-3): 11. (1914a); Pl. Tripol. p.: 14. (1914c).

Type: Libia, Cirenaica, Tarhuna: Uadi Ksea, Ras Argobinani (2483), 8/04/1913. Leg. R. Pampanini (FI, Lectotypus designated here).

Other material, Syntypi: Tarhuna: Kasr Daun (4401), 7/04/1913; Garian: Ras Tecut (3805), 26/04/1913; Garian: Uadi Garian (3852), 26/04/1913; Garian: Bu Gheilan (4402), 24/04/1913. Leg. R. Pampanini, (all material in FI).

Accepted name: Brachypodium distachyon (L.) P. Beauv.

Note: Pampanini's taxon is accepted by Weiller M. in Maire R. \& Weiller M., Fl. Afrique N.: 281. 1955.

New taxon: Brachypodium distachyon var. velutinum f. gussonei Pamp. in Arch. Bot. XII (2): 18. (1936a); Rend. Sem. Fac. Sc. Univ. Cagliari, VIII (3): 61. (1938).

Type: Libia, Cirenaica: Slonta, steppa sassosa (423), 17/04/1933. Leg. R. Pampanini \& R.E.G. Pichi Sermolli, (FI, Lectotypus designated here).

Other material, Syntypi: Cirenaica, Cirene, Melchifaf (424), 7/04/1933. Leg. R. Pampanini.

Cirenaica, Cirene: Uadi Belgadir (426), 26/04/1934; Cirenaica, El Beda: Uadi Uardama (427), 2/05/1934; Cirenaica, El Beda: Uadi Scisu (428), 7/05/1934; Cirenaica: Derna (425), 21/04/1934. Leg. R. Pampanini \& R.E.G. Pichi Sermolli.

Accepted name: Brachypodium distachyon (L.) P. Beauv.

Note: because of the lack of a recent systematic investigation, at present this name is accepted as a synonym of $B$. distachyon. The intent by the author of establishing the new form is clearly expressed in the sheet label of Lectotypus.

New taxon: Bromus chrysopogon Viv. in Fl. Libyc. Spec.: 4. t. 2. 1824 [before August 1824]

Type: Neotypus: Cirenaica, Merg: Sidi Gibrin, 17/03/1922. Leg. A. Maugini, det. R. Pampanini as Bromus scoparius L. var. psilostachys Hal., (by Scholz H., Willdenowia 7 (2): 409. 1974a) (FI).

Accepted name: Bromus chrysopogon Viv. (Valdés \& Scholz 2009). 
New taxon: Bromus fasciculatus f. parlatorei Pamp. in Arch. Bot. XII (2): 18. (1936a); Rend. Sem. Fac. Sc. Univ. Cagliari, VIII(3): 61. (1938).

Type: Libia, Cirenaica, fra Bir Acheim e Mechili: 1.d. Bir Zeidan (470), 26/03/1933. Leg. R. Pampanini (FI, Lectotypus designated here).

Other material, Syntypi: Cirenaica, Bir Acheim-Acroma: 1.d. Sedra (468), 22/03/1933; Cirenaica fra Tobruk e Bardia: 1.d. Sidi Bu Amud (469), 23/03/1933. Leg. R. Pampanini, (all material in FI).

Accepted name: Anisantha fasciculata (C. Presl) Nevski (Valdés \& Scholz 2009).

Note: Pampanini (loc. cit.) identifies his plant with Bromus fasciculatus $\mathrm{f}$. b of Parlatore (Fl. It. I: 411. 1850) who provides a short description of this variant but not the name: "spiculis pubescentibus, palea superior longius ciliata". This morphotype, the same as the Libya material in FI, possibly marks the southern portion of the Mediterranean range of the species, which northwards includes at least Sicily and Pantelleria.

New taxon: Bromus hordaceus var. molliformis f. villosus Pamp. in Bull. Soc. Bot. Ital. (13): 11. (1914a); Pl. Tripol. p.: 16. (1914c).

Type: Holotypus: [Libya], Tripolitania, Tarhuna: Uadi Msaaba a Kasr Doga, nell'acquitrinio (972), 18/03/1913. Leg. R. Pampanini (FI). (Indicated by C. Steinberg in Bot. Jahrb. Syst. 102 (1-4): 419. 1981).

Accepted name: Bromus hordeaceus L. subsp. molliformis (Billot) Maire \& Weiller.

Note: the specimen, as annotated by H. Scholz (revision 1971, FI in sched.), is too young to be definitively determined.

New taxon: Bromus macrostachys f. pubescens Pamp. in Arch. Bot. XII (1): 18. (1936a); Rend. Sem. Fac. Sc. Univ. Cagliari, VIII (3): 61. (1938).

Type: Libia, Cirenaica, el-Beda, Uadi Scisu (495), 07/05/1934. Leg. R. Pampanini \& R.E.G. Pichi Sermolli, (FI, Lectotypus designated here).

Other material, Syntypi: Libia, Cirenaica, Barce: 1.d. Sidi Ahmed Cheila (488), 06/04/1933. Leg. R. Pampanini. Cirenaica, Derna: Uadi Naga (489), 21/04/1934; Cirenaica: Lamluda; Cirenaica, el-Beda: Uadi Messaf-saf Ain Legmeila (490), 22/04/1934; Cirenaica, el-Beda, Uadi El Kuf: 1.d. Bu Breica (493), 27/04/1934; Labrach [el-Abrach on label], Mghernes, (494), 04/05/1934; Slonta, macchia (492), 25/04/1934 Leg. R. Pampanini \& R.E.G. Pichi Sermolli, (all material in FI).

Accepted name: Bromus alopecuros L. subsp. biaristulatus (Maire) Acedo \& Llamas (Acedo C. \& Llamas F., Fl. Medit. 4: 203-212. 1994).

Note: the current synonym (basionym) is Bromus lanceolatus Roth subsp. biaristulatus Maire. The specimen collected at Lamluda is not in FI.

New taxon: Bromus rubens f. intermedius Pamp. in Bull. Soc. Bot. Ital. (1-3): 11. (1914a); Pl. Tripol.: 17. (1914c).

Type: Holotypus: [Libya], Tripolitania, Tarhuna: Colline a est di Kasr Tarhuna (1834), 28/03/1913. Leg. R. Pampanini, (FI). (Indicated by C. Steinberg in Bot. Jahrb. Syst. 102 (1-4): 422. 1981).

Accepted name: Anisantha rigida (Roth) Hyl. (Valdés \& Scholz 2009; marked as Bromus rigidus Roth by K. Ammann, 14/12/1990). 
Note: this taxon has nothing to do with Anisantha rubens (L.) Nevski (三Bromus rubens L.) which bears much smaller spikelets, glumes and lemmas.

New taxon: Ctenopsis pectinella var. pubescens Pamp. in Bull. Soc. Bot. Ital. (1-3): 11. (1914a); Fl. Tripol.: 19. (1914c).

Type: [Libya], Tripolitania, Uadi Teziu(v)a (Tersiva) nella steppa (1953), 1/04/1913. Leg. R. Pampanini, (FI, Lectotypus designated here).

Other material, Syntypi: Tripolitania, Tarhuna: Colline a E di Kasr Tarhuna (1845), 28/03/1913; idem (2113), 4/04/1913; Tripolitania: Kasr Daun (2294), 7/04/1913. Leg. R. Pampanini, (all material in FI).

Accepted name: Festuca pectinella Delile ( $\equiv$ Ctenopsis pectinella [Delile] De Not. $\equiv$ Vulpia pectinella [Delile] Boiss.).

Note: nowadays Ctenopsis De Not. and Vulpia C.C. Gmel. are better regarded as sections of Festuca L. (Soreng \& al. 2015).

New taxon: Dactylis glomerata var. spicata Pamp. in Arch. Bot. XII (2): 19. (1936a) [D. glomerata, Prod. Fl. Cir. p. 116, var. hispanica, Prod. Fl. Cir. p. 116 (p.p. specim Cassinera)]; Rend. Sem. Fac. Sc. Univ. Cagliari, VIII(3): 61. (1938).

Type: Libia, Cirenaica, Umm er-Rzem a sud est di Barce, Uadi Suenia (622), 18/04/1934, FI003601. Leg. R. Pampanini \& R.E.G. Pichi Sermolli, (Lectotypus designated here).

Other material, Syntypi:

Published by Pampanini (1938): Cirenaica, Naughia a sud est di Bengasi (611), 10/03/1933, FI003606; Cirenaica, fra Bengasi e Soluch, Giardina (612), 10/03/1933, FI003607; Cirenaica, Apollonia, 1. d. Rgua (618), 11/04/1933, FI003613; Cirenaica, fra Derna e Mechili: 1. d. Siret Medanaat (616), 10/04/1933, FI003512; Cirenaica, Martuba, Uadi Bgar (615), 08/04/1933, FI003611; Cirenaica, Marmarica, fra Tobruk e Bardia, Uadi Sahal (613), 23/03/1933, FI003608. Leg. R. Pampanini.

Cirenaica, tra Bengasi e Agedabia, Sidi Ahmed el-Magrun (619), 07/04/1934, FI003614; Cirenaica, Uadi Scechaba (625), 01/05/1934, FI003598; Cirenaica, Messa, Uadi Tmista (624), 29/04/1934, FI003599; Cirenaica, Messa a ovest di Cirene, Sfonta (628), 08/05/1934, FI003595; Cirenaica, Beda, Uadi Madfa (626), 01/05/1934, FI003597; Cirenaica, Uadi Msuria (629), 10/05/1934, FI003604; Cirenaica, Umm erRzem a sud est di Barce (621), 18/04, FI003603; Cirenaica, Uadi Scisu (627), 07/05/1934, FI003596; Cirenaica, Chersa (620), 16/04/1934, FI003602; Cirenaica, elGhegab a sud est di Cirene, steppa a Poterium (623), 28/04/1934, FI003600; Cirenaica, fra Gubba e l'Uadi Latrun: 1.d. Argub Dasc (630), 14/05/1934, FI003615. Leg. R. Pampanini \& R.E.G. Pichi Sermolli.

Cited by Pampanini (1936) in the protologue: Cirenaica, Marmarica, Tobruk, 1918, Leg. F. Cassinera. Cirenaica, Bengasi, Karmu, 28/02; Bengasi, fra Guarscià e Gariunes, 10/03; Bengasi, Suani Bazar, 10/03; Bengasi, Rahba, 13/03; Bengasi, fra Ganfuda e Suani Tica, 26/03; Regima, primavera; Bengasi, Sidi Kalifa, primavera; Bengasi, Lete, primavera; Bengasi, Ganfuda, primavera; Bengasi, Selmani, primavera; Bengasi, Kuebia, primavera; Bengasi, Kseibia, primavera; Derna, primavera 1922. Leg. A. Maugini, (all material in FI).

Unpublished: el-Gubba (617), 07/04, FI003610; Umm er Rzem (614), 08/04/1933, 
FI003609. Leg. R. Pampanini; tra Barce e Tocra Bu Goeir (613), 15/5/1934, FI003605. Leg. R. Pampanini \& R.E.G. Pichi Sermolli. (FI).

Accepted name: Dactylis glomerata L.

Note: the pattern of diversity in D. glomerata is far from being understood, especially in the North African sector of its range. The proposal of even specific rank (Dactylis spicata [Pamp.] Guglielmo \& Scalia in Boll. Accad. Gioenia Sci. Nat. Catania 18 [325]: 234. 1985) is currently devoid of any justification.

New taxon: Dactylis glomerata var. spicata f. intermedia Pamp. in Arch. Bot. XII (2): 19. (1936a) (D. glomerata var. hispanica, Prod. Fl. Cir, p. 117 p.p. specim. Zanon, Maugini); Rend. Sem. Fac. Sc. Univ. Cagliari, VIII (3): 61. (1938).

Type: Libia, Cirenaica, Cirene: Ghegab a sud est di Cirene, steppa a Poterium (640), 28/04/1934. Leg. R. Pampanini \& R.E.G. Pichi Sermolli, (FI003656, Lectotypus designated here).

Other material, Syntypi:

Published by Pampanini (1938):

Cirenaica, fra Tocra e Tolmeta (636), 28/04/1933, FI003648; Cirenaica, Slonta (635), 17/04/1933, FI003647; Cirenaica, Slonta, steppa a Poterium (634), 17/04/1933, FI003646; Cirenaica, Derna, Uadi Naga (633), 09/04/1933, FI003645; Cirenaica, Martuba, Uadi Bgar (632), 08/04/1933, FI003644. Leg. R. Pampanini.

Cirenaica, Cirene, Uadi Hofra (645), 05/05/1934, FI003661; Cirenaica, Messa, Gasr Zaarura (641), 03/05/1934, FI003657; Cirenaica, Beda, 1.d. Sfeiat (642), 04/05/1934, FI003658; Cirenaica, Uadi Scisu (646), 07/05/1934, FI003662; Cirenaica, el-Abrach, Mghernes (643), 04/05/1934, FI003659; Cirenaica, el-Abrach, Mghernes, macchia (644), 04/05/1934, FI003660; Cirenaica, fra Gubba e Uadi Latrun, 1.d. Argub Dasc (648), 14/05/1934, FI003664; Cirenaica, Uadi Derna (647), 12/05/1934, FI003663; Cirenaica, Bomba, 1.d. El Gefar (638), 8/4/1934, FI003650; Cirenaica, fra Gubba e Uadi el-Atrun, 1.d. Argub Gazal (649), 14/05/1934, FI3665; Cirenaica, Marana a est di Barce steppa a Artemisia (639), 25/04/1934, FI003651; Cirenaica, tra Bengasi e Agedabia Sidi Ahmed el-Magrun (637), 7/4/1934. Leg. Pampanini \& R.E.G. Pichi Sermolli, (FI003649).

Cited by Pampanini (1936) in the protologue: Cirenaica, Bengasi: [between] due Palme e Benina (452), 16/03; Cirenaica, Bengasi, Raaba (563), 13/04; Cirenaica, Bengasi, Cimitero nuovo, luogo ombroso (563), 20/03/1916. Leg. V. Zanon.

Cirenaica, Derna: vivaio di Derna, primavera; Cirenaica, Merg, Ridotta Zorda, 30/03; Cirenaica, Merg, piana a ovest di Merg., 09/04; Bengasi: Rahba, 15/03/1922; Cirenaica: Ma(a)tan Borgù, 06/1919 (2 campioni). Leg. A. Maugini. (all material in FI).

Accepted name: Dactylis glomerata L.

Note: see the discussion for var. spicata.

New taxon: Diplachne festuciformis H. Scholz in Willdenowia 11(1): 98. 1981.

Typus: Holotypus: Fezzan: El Jofra, Socna, oasi artificiale, campi. Leg. C. Ricceri \& H. Steinberg (sub Puccinellia distans Parl. aff. subsp. festuciformis) (FI).

Accepted name: Diplachne uninervia (J.Presl) Parodi.

Note: marked as holotypus by H. Scholz 1981 and reidentified as Leptochloa fusca subsp. 
uninervia (J. Presl) N. Snow by N. Snow, 31/08/2007. The accepted name in Valdés \& Scholz (2009) is Leptochloa uninervia (J. Presl) Hitchc. \& Chase, where the choice of the specific rank is undoubtedly suitable. However, it was demonstrated (Hilu \& Alice 2001; Peterson \& al. 2012) that Diplachne P. Beauv. and Leptochloa P. Beauv. are monophyletic, non-sister lineages, so Soreng \& al. (2015) have provided the final separation of the two genera in the subtribe Eleusininae. These are easily distinguished by the synapomorphies of the spikelet that is dorsally compressed in Diplachne, laterally compressed in Leptochloa.

New taxon: Koeleria pubescens var. tripolitana Domin in Bull. Soc. Bot. Ital. (1-3): 12. (1914a); P1. Tripol.: 24. (1914c).

Type: [Libya], Tripolitania, Tripoli: Ain Zara (3464), nell'acquitrinio, 22/04/1913. Leg. R. Pampanini, (FI, Lectotypus designated here).

Other material, Syntypus: Tripolitania, Garian: uadi Garian (4345), 07/05/1913. Leg. R. Pampanini, (FI).

Accepted name: Rostraria litorea (All.) Holub

Note: mistakenly reported in Valdés \& Scholz (2009) as Rostraria pubescens (Lam.) Trin.

New taxon: Koeleria salzmannii var. cossoniana f. glabra Pamp. in Arch. Bot. XII (2): 19. (1936a); Rend. Sem. Fac. Sc. Univ. Cagliari, VIII(3): 62. (1938).

Type: Libia, Cirenaica: Tra Agedabia ed el-Agheila 1.d. Melch en Nogra, 15/03/1933 (801), 15/03/1933. Leg. R. Pampanini, (FI, Lectotypus designated here).

Other material, Syntypi: Cirenaica, Marsa Brega; Cirenaica, Agedabia, Haseiat, 1. d. Bag Lia; Cirenaica, fra Agedabia e Sonnu; Cirenaica, Zuetina 1933-34. Leg. R. Pampanini \& R.E.G. Pichi Sermolli.

Accepted name: Rostraria salzmannii (Boiss.) Holub (Dobignard \& Chatelain 2010).

Note: in FI there is the lectotype (no. 801), while the remaining original material, cited by Pampanini (1938), is missing.

New taxon: Koeleria salzmannii var. cossoniana f. lobulata Domin in Bull. Soc. Bot. Ital. (1-3): 12. (1914a); P1. Tripol.: 25. (1914c).

Type: Holotypus: [Libya], Tripolitania, Garian: Bu Gheilan, nell'acquitrinio (3670), 24/04/1913. Leg. R. Pampanini, (FI).

Accepted name: Rostraria salzmannii (Boiss.) Holub (Dobignard \& Chatelain 2010).

Note: further original material referable to this taxon doesn't seem to exist.

New taxon: Koeleria salzmannii var. cossoniana f. villosa Pamp. in Arch. Bot. XII (2): 20. (1936a); Rend. Sem. Fac. Sc. Univ. Cagliari, VIII (3): 62. (1938).

Type: Libia, Cirenaica, Ridotta Tilger a 10 km da Agedabia, (808), 07/04/1934. Leg. R. Pampanini \& R.E.G. Pichi Sermolli, (FI, Lectotypus designated here).

Other material: Syntypus: Cirenaica, tra Agedabia ed el-Agheila: 1.d. Melch en Nogra (807), 15/03/1933. Leg. R. Pampanini, (FI).

Accepted name: Rostraria salzmannii (Boiss.) Holub (Dobignard \& Chatelain 2010). 
New taxon: Koeleria salzmannii var. longiflora Domin in Bull. Soc. Bot. Ital. (1-3): 12. (1914a); Pl. Tripol.: 26. (1914c) (in herb. sub var. longiglumis).

Type: [Libya], Tripolitania, Tarhuna: Abiar Milgah, sul Ras Ter (1098), 19/03/1913. Leg. R. Pampanini, (FI, Lectotypus designated here).

Other material, Syntypi: Tripolitania, Tarhuna: Pianura di Kam el-Gaar (1877), 31/03/1913; Tripolitania, Tarhuna: Uadi Msaaba (839), 18/03/1913; Tripolitania, Tarhuna: Abiar Milgah a Migi (1059), 19/03/1913. Leg. R. Pampanini, (all material in FI).

Accepted name: Rostraria salzmannii (Boiss.) Holub

Note: in Bull. Soc. Bot. Ital. 1914 is published only the sheet no. 1877, but subsequently in Pl. Tripol.: 26 also the specimens 839, 1059 and 1098 (lectotype) are published; they all belong to the original material. In the same work Pampanini refers about the Domin's opinion that two forms are recognizable, the first one "f. minor" labelled "aristulis brevioribus" [shorter awns], corresponds to the sheet 839 , the second one, without a name but with a short description, corresponds to the sheet no. 1059 .

New taxon: Koeleria salzmannii var. longiflora subvar. aurata Pamp. in Bull. Soc. Bot. Ital. (1-3): 12. (1914a); Pl. Tripol. p: 26. (1914c). (in herb. sub K. salzmannii var. cossoniana subvar. aurata Pamp.

Type: [Libya], Tripolitania, Tarhuna, Ras Ghenai (4383), 25/03/1913. Leg. R. Pampanini, (FI, Lectotypus designated here).

Other material: Syntypus: Tripolitania, Tarhuna, Colline a est di Kasr Tarhuna (1835), 28/03/1913. Leg. R. Pampanini, (FI).

Accepted name: Rostraria salzmannii (Boiss.) Holub

New taxon: Koeleria salzmannii var. pampaninii Domin in Bull. Soc. Bot. Ital. (1-3): 12. (1914a); P1. Tripol.: 26. (1914c).

Type: [Libya], Tripolitania, Tripoli: Ain Zara, nell'acquitrino (3466), 22/04/1913. Leg. R. Pampanini, (FI, Lectotypus designated here).

Other material: Syntypus: Tripolitania, Tarhuna, Uadi Ksea, Ras Argobinani (2422), 08/04/1913. Leg. R. Pampanini, (FI).

Accepted name: Rostraria salzmannii (Boiss.) Holub

Note: the specimen no. 2422 is dubitatively cited by Pampanini (1914b) but is probably lost in FI; the lectotype sheet bears an autograph label of Domin.

New taxon: Lagurus ovatus f. oblongus Pamp. in Bull. Soc. Bot. Ital. (1-3): 12. (1914a); Pl. Tripol.: 27. (1914c).

Type: Holotypus: [Libya], Tripolitania, Tripoli, Suani Beni Aden, nella steppa [2(1)4], 25 febbraio 1913. Leg. R. Pampanini, (FI).

Accepted name: Lagurus ovatus L. subsp. ovatus (marked by Messeri 1942, as Lagurus ovatus subsp. communis var. genuinus Messeri).

Note: in Pampanini's P1. Tripol. (1914), certainly in error, the sheet is indicated as no. 214 instead of 24; on the other hand all publication data fit perfectly the data labelled on the specimen sheet, which also represents the only evidence for this taxon in FI. 
New taxon: Libyella Pamp. in Bull. Soc. Bot. Ital.: 150. 1925.; Libya, I: 68-74. 1927.

Type: Libyella cyrenaica (Durand \& Barr.) Pamp., basionym: Poa cyrenaica Durand \& Barratte Fl. Lib. Prodr. I: 268. 1910.

Accepted name: Poa L. (Soreng \& al. 2015).

Note: monospecific genus, see Poa cyrenaica.

New taxon: Oryzopsis coerulescens var. grandis Pamp. in Arch. Bot. XII (2): 20. (1936a); Rend. Sem. Fac. Sc. Univ. Cagliari, VIII(3): 62. (1938).

Type: Holotypus: Libia, Cirenaica: Ain Mara (926), 28/04/1934. Leg. R. Pampanini \& R.E.G. Pichi Sermolli, (FI).

Accepted name: Piptatherum holciforme subsp. longiglume (Hausskn.) Freitag (Valdés \& Scholz 2009).

Note: marked by H. Scholz (1971) as the typus of Oryzopsis coerulescens var. grandis Pamp. The same author in Willdenowia 7(2): 420. 1974 refers to the typus in FI but doesn't provide any information on collecting data, making the typification invalid.

New taxon: Poa cyrenaica Durand \& Barratte in Fl. Lib. Prodr. I: 268. 1910.

Type: [Libya], Cyrenaica, Bengasi (379), 10/02/1883. Leg. Ruhmer (FI, Lectotypus designated here).

Accepted name: Poa cyrenaica Durand \& Barr.

Note: the sheet no. 379 was labelled (in 2014) by R. Soreng (US) as isotypus, but he never designated a type (Soreng in litteris 2014); likewise M. Röser (Hal), who has been involved in studies on Libyella, didn't designate any type for this genus (Röser in litteris 2014).

New taxon: Poa vaginata Pamp. in Arch. Bot. XII (2): 20. (1936a); Rend. Sem. Fac. Sc. Univ. Cagliari VIII (3): 62. (1938).

Type: Holotypus: Libia, Cirenaica, Umm er Rzem a sud est di Barce: Uadi Suenia (1060), 18/4/1934. Leg. R Pampanini \& R.E.G. Pichi Sermolli, (FI003616).

Accepted name: Poa vaginata Pamp. (Valdés \& Scholz 2009; Dobignard \& Chatelain 2010).

Note: in Sherif \& Siddiqi (1988) curiously two other specimens are cited that were collected by Pampanini and not cited by him. The reason is due to the fact that the two mentioned specimens were identified as $P$. vaginata not by Pampanini but by H. Scholz (1971) which had borrowed them. Although the authors of Poaceae in Flora of Libya, refer to them at FI, they had not seen them, but simply consulted the specimina visa of Scholz's paper as is also evident from the citation of that work in their bibliography, used to make the record of this taxon in the Libyan flora. The same applies to the indication of the typus which is only a bibliographic citation. The two samples are: Cyrenaica, southeast of Barce, Wadi el Bgar (1024), 04.08.1933. Leg. R. Pampanini; Cyrenaica, between Derna and Mechili, Gat and Dghigh (1028), 04.10.1933. Leg. R. Pampanini (sub Poa bulbosa L.), which obviously are not part of the original collection. 
New taxon: Polypogon monspeliensis f. exilis Pamp. in Agric. Colon., XXII: 362-63, t. I, f. 5 (recto). 1928. Considered relative to this taxon is also the material of $P$. monspeliensis Desf. indicated in Agric. Colon. XX: 457. (1926).

Type: [Libya], Cirenaica: Oasi di Giarabub, 02/06/1926 (field label), 06-07/1926 (herbarium label). Leg. G. Krüger, (FI, Lectotypus designated here).

Other material, Syntypi: Cirenaica, Oasi di Giarabub, 01/06 and 06/1926 (field labels concerning the same sample), 06-07/1926 (herbarium labels); Cirenaica, Giarabub, 24/02/1927 (field labels), 10/02/1927 (herbarium labels). Leg G. Krüger, (all material in FI).

Accepted name: Polypogon monspeliensis (L.) Desf.

Note: possibly synonym of var. minor Coss. \& Durieu (Algeria), which is also a synonym of the species (Dobignard \& Chatelain 2010).

New taxon: Scleropoa philistaea f. pauciflora Pamp. in Bull. Soc. Bot. Ital. (1-3): 12. (1914a); Pl. Tripol.: 36. (1914c).

Type: Holotypus: [Libya], Tripolitania, Tarhuna: Uadi Msaaba a Kars Doga, nell'acquitrinio (958), 18/03/1913. Leg. R. Pampanini, (FI).

Accepted name: Desmazeria philistaea (Boiss.) H. Scholz

Note: likely a depauperate individual falling within the normal variability of the species.

New taxon: Vulpia danthonii var. tripolitana Pamp. in Bull. Soc. Bot. Ital. (1-3): 12 . (1914a); Pl. Tripol. p.: 39. (1914c).

Type: [Libya], Tripolitania, Garian: Kasr Garian, margini dei campi (4312), 4/05/1913. Leg. R. Pampanini, (FI, Lectotypus designated here).

Other material, Syntypus: Tripolitania, Tarhuna, Uadi Sart (4397), 27/03/1913. Leg. R. Pampanini, (FI).

Accepted name: Festuca danthonii Asch. \& Graebn.

Note: a better known synonym of Pampanini's taxon is Vulpia ciliata Dumort. var. tripolitana (Pamp.) Maire \& Weiller. It represents no more than the expression of an accentuated hairiness in glumes and lemmas within the normal range of the species. For the inclusion of the species in the genus Festuca, see Soreng \& al. (2015).

\section{Potamogetonaceae (S. Miranda)}

New taxon: Potamogeton crispus f. integrifolius Corti in Flora e Vegetazione del Fezzan e della Regione di Gat. Reale Società Geografica Italiana 1: 28. 1942.

Type: Holotypus: [Libya], Fezzan occidentale, Regione di Gat: Tunin (Gat) $2^{\circ}$ deposito d'acqua, (1280), 700 m., 05/03/1934. Leg. R. Corti, (FI).

Accepted name: Potamogeton crispus L. sensu Fl. Lib. 114: 7-8. 1984 b.

Note: on the sheet there is a small label bearing a handwritten note in pencil by Corti.

\section{Primulaceae (P. Cuccuini \& C. Nepi)}

New taxon: Anagallis linifolia f. candida Pamp. in Bull. Soc. Bot. Ital. (1-3): 15. (1914a); Pl. Tripol.: 187. (1914c)

Type: Holotypus: [Libya], Tripolitania, Garian: Kasr Garian, nei campi incolti (nei maggesi [on the label]) (4130), 30/04/1913. Leg. R. Pampanini, (FI). 
Accepted name: Lysimachia monelli subsp. linifolia (L.) Peruzzi see Dobignard \& Chatelain 5: 168. 2013, s.1.

New taxon: Anagallis linifolia var. litoralis Pamp. in Bull. Soc. Bot. Ital. (1-3): 15. (1914a); P1. Tripol.: 187. (1914c).

Type: Holotypus: [Libya], Tripolitania, Tripoli: Fra Tripoli e Gargaresc (22), 14/02/1913. Leg. R. Pampanini.

Accepted name: Lysimachia monelli L. subsp. monelli, see Dobignard \& Chatelain 5: 168. 2013.

New taxon: Coris monspeliensis var. syrtica f. dentata Pamp. in Bull. Soc. Bot. Ital. (4-9): 18. 1920.

Original material: Libia, Tripolitania: dintorni di Nalut, 1913. Leg. Capitano Antonetti.

Accepted name: Coris monspeliensis L. sensu Ali S. I. in Fl. Lib 6: 1-3. 1077.

Note: the exsiccatum came to Pampanini by means of E. Chiovenda who, in turn, had received it from General A. Zola together with further specimens collected by others in Tripolitania. The specimen, collected by a soldier, Captain Antonetti, is not present in FI, nor in RO (A. Tilia in litteris 2016).

\section{Ranunculaceae (P. Cuccuini \& C. Nepi)}

New taxon: Adonis microcarpa var. intermedia f. lutea Pamp. in Bull Soc. Bot. Ital. (1-3): 14. (1914a); Pl. Tripol.: 117. (1914c).

Type: [Libya]: Tripolitania, Tarhuna: Ras Ghenai (1553), 25/03/1913. Leg. R. Pampanini, (FI, Lectotypus designated here).

Syntypi from the original collection: [Libya], Tripolitania, Mesellata: Cussabat, nelle messi (2699), 10/04; Me.: Cussabat, nei margini dei campi (2744), 10/04; Me.: sul Ras Gelà (3082), 13/04; T., Tarhuna: Ras Bu Tauil (1301), 21/04; Ta.: Uadi Tenziua, nelle messi (1971), 01/04; Ta.: Uadi Ksea sul Ras Argobinani (2509), 08/04/1913. Leg. R. Pampanini.

Accepted name: Adonis microcarpa DC. by C. Steinberg, (07/1970).

Note: in FI there are specimen nos. 1553 and 3082 only. In Fl. du l'Afr. du Nord, Quézel includes our taxon under $A$. dentata (Quézel 1964). Indeed he considers $A$. dentata as subdivided into three varieties: genuina, intermedia and microcarpa and lists a series of related subvarieties, among which the subvar. lutea is the one with "yellow flowers" but without specifying to which var. it refers. For this reason it was not possible to relate the names of the two taxa together (which, in any case, would refer to comb. and stat nov.).

New taxon: Clematis flammula var. sancti-marini f. angustissima Pamp. in Nuovo Gior. Bot. Ital. n.s. 31: 211. (1924).

Type: [Libya], Cirenaica, Regione di Merg: Uadi Umm el Anain, 28/05/1922. Leg. A. Maugini, (FI001167, Lectotypus designated here); previously quoted as Holotypus by Wang Wen-Tsai in Acta Phytotaxonomica Sinica 41(2): 158. 2003, see note.

Isolectotypus: (FI). 
Accepted name: Clematis flammula var. stenophylla Heldr. ex Huntze see Wang WenTsai, in Acta Phytotaxonomica Sinica 41(2): 153-158. 2003.

Note: there are two specimens in FI which carry the data for the previously mentioned taxon. The Editor for the Ranunculaceae Family, Wang Wen-Tsiai (2003) examined both specimens twice (as shown by the photographs loaned on 06/05/2000 to $\mathrm{G}$ and on 04/07/2001 to PE).

Since the FI technician who took the photographs numbered the two images twice both times, taking the second as an attachment to the first, the Chinese scholar was probably misled and mistakenly believed that the collection consisted of two sheets somehow linked together, a situation which he did not make clear. This is not the case, as the two specimens are clearly autonomous. For this reason we are dealing with a case of mistaken identity of the type itself (see article 9.9 of ICN-McNeill \& al. 2012) which consequently should not be defined as a Holotypus but rather as a Lectotypus. The lectotypus, although effectively established, consists of two distinct, unrelated specimens. One single specimen, indicated as FI001167, can therefore be designed here (2nd step) as Lectotypus (see article 9.17 of ICN-McNeil \& al. 2012).

New taxon: Ranunculus asiaticus var. bereniceus Pamp. in Nuovo Gior. Bot. Ital. n.s. 24: 136. (1917).

Original material: [Libya], Cirenaica: Fuehat, 03/03 (319bis); C.: Due Palme, luoghi rocciosi, 03/03, (228, 228 bis), 26/02/1916 ( 267). Leg. V. Zanon.

Accepted name: Ranunculus asiaticus L., see Dobignard \& Chatelain 5: 190. 2013.

Note: the author, in Pampanini (1916), thinks that the new variety described is a hybrid between $R$. asiaticus var. flavus and $R$. asiaticus var. grandiflorus. The material is not kept in FI.

New taxon: Ranunculus asiaticus var. bicolor Pamp. in Bull Soc. Bot. Ital. (1-3): 14. (1914a); Pl. Tripol.: 119. (1914c).

Typus: [Libya], Tripolitania, Tarhuna: Abiar Milgha, (437), 28/02/1913. Leg. R. Pampanini, (FI003792, Lectotypus designated here).

Isolectotypi: (441-FI003790, 436-FI003793, 438-FI003791, 439-FI003784, 4468FI003785).

Other syntypi from the original collection: [Libya], Tarhuna.: Abiar Milgha a Migi (4469), 28/02, (FI003789); Ta.: Abiar Milgha sul Ras Ter (1087), 19/03, (FI003787); Ta.: Kasr Tarhuna (628), 12/03, (FI003788); Ta.: Ain Scersciara (633), 14/03/1913. Leg. R. Pampanini, (FI003786).

Accepted name: Ranunculus asiaticus L. see Dobignard \& Chatelain 5: 190. 2013; also in Fl. Lib. 108. 1984.

New taxon: Ranunculus asiaticus var. grandiflorus Bég. \& Vaccari in Ann. di Bot. XII(1):105. 1914.

Original material: [Libya]: Tripolitania: Misrata nei campi arenosi e lungo la sebckha tra questa città e Ras Zurug, 06/03/1913. Leg. A. Vaccari.

Accepted name: Ranunculus asiaticus L. see Dobignard \& Chatelain 5: 190. 2013.

Note: the material is not kept in FI; other material is present in MOD (non vidi). 
New taxon: Ranunculus asiaticus var. intermedius Pamp. in Arch. Bot. XII(1): 25. (1936a); Rend. Sem. Fac. Sc. Univ. Cagliari VIII(3): 65. (1938).

Type: Libia, Cirenaica: Cirene 1.d. Melchifaf (2733), 7/4/1933. Leg. R. Pampanini, (FI003492, Lectotypus designated here).

Other syntypi from the original collection: Libia, Cirenaica, Cirene: es Saf-Saf (2734), 18/04/1933. Leg. R. Pampanini, (FI003493). C., Umm er Rzem, a sud est di Barce: Uadi esc Suenia (2735), 18/4/1934. Leg. R. Pampanini \& R.E.G. Pichi Sermolli, (FI003494).

Accepted name: Ranunculus asiaticus L. in Dobignard \& Chatelain 5: 190. 2013.

Note: on the sheet of Lectotypus (FI003492) there is a piece of newspaper with the name of the new taxon handwritten in blue pencil by Pampanini.

New taxon: Ranunculus asiaticus var. kermesinus Pamp. in Arch. Bot. XII(1): 25. (1936a); Rend. Sem. Fac. Sc. Univ. Cagliari VIII(3): 65. (1938).

Type: Holotypus: Libia, Cirenaica, Cirene: 1.d. Melchifaf (2736), 7/04/1933. Leg. R. Pampanini, (FI).

Accepted name: Ranunculus asiaticus L. s.1.

Note: on the specimen there is a piece of newspaper with the name of the new taxon handwritten in blue pencil by Pampanini.

New taxon: Ranunculus asiaticus var. sanguineus f. purpureus Bég. \& Vaccari in Schedae ad Fl. Lyb. Exs. P. 35, n 100 (1914), nomen nudum.

Original Collection: [Libya], Cyrenaica: Derna, sulle colline alt. 1"-300 m. 1914; Leg. A. Vaccari (FI ?, PAD!).

Accepted name: Ranunculus asiaticus L.

Note: this specimen is not kept in FI.

New taxon: Ranunculus asiaticus var. vulgaris f. croceus Bég. \& Vaccari in Schedae ad Fl. Lyb. Exs., 35. n 99. 1913, nomen nudum. Contr. Fl. Lib.: 46. 1912; Sec. Contr. Fl. Lib. Roma: 26. 1913 (idem ma senza località); Modena 22; Terzo Contrib. Fl. Lib., Ann. Di Bot. 12: 105. 1913 (idem). (All sub R. asiaticus var. vulgaris DC.)

Original material: [Libya, Cyrenaica], Marmarica: Tobruk, in collibus aridis saxosis, solo calcareo, 01/03/1913. Leg. A. Vaccari (FI).

Accepted name: Ranunculus asiaticus L. see Dobignard \& Chatelain 5: 190. 2013.

Note: only one specimen corresponds to this name in FI (published as Sched. $n^{\circ} 99$ in FI. Lib. Exs) and is sub R. asiaticus var. grandiflorus. The publication does not give any explicit description of the morphological characteristics.

The bibliographical citations mentioned on the sched. $n^{\circ} 99$ of FI. Lib. Exs. all refer to $R$. asiaticus var. vulgaris DC. and relate to the following specimens respectively: Marmarica: Tobruk nei colli aridi i calcarei, 24/01, 20/02/1912. Leg. A. Vaccari.; sine loco; Marmarica: Tobruk nella costa sud del golfo, 12/01/1913. Leg. A. Vaccari.

New taxon: Ranunculus bullatus var. cyrenaicus Pamp. in Nuovo Gior. Bot. Ital. n.s. 26: 212 (1919).

Type: Lectotypus: [Libya], Cirenaica, Bengasi: Fra le Due Palme e la linea ferroviaria di Benina, in direzione del Giok Kebir (24), 05/01/1917. Leg. V. Zanon, (FI001168). 
Marked as Lectotypus by R. M. Baldini, 11/04/2000, and later typified by R. Baldini \& C. Jarvis, in Bull. Nat. Hist. Mus. Lond. (Bot.) 32(1): 11. 2002.

Other syntypi from the original collection: Cirenaica, Bengasi: Due Palme (24), 01/1915, (FI003679); C. Bengasi: Casa Auari (50 C), 12/1917, (FI003696). Leg. V. Zanon.

Accepted name: Ranunculus cytheraeus (Halácsy) Baldini, in Baldini \& Jarvis, (2002).

New taxon: Ranunculus cyclocarpus Pamp. in Arch. Bot. XII(1): 25-26. (1936a); Rend. Sem. Fac. Sc. Univ. Cagliari VIII(3): 65. (1938).

Type: Libia, Cirenaica: Apollonia, 1.d. Rgua (2750), 11/04/1933. Leg. R. Pampanini, (FI003469, Lectotypus designated here).

Other syntypi from the original collection: Libia, Cirenaica, Cirene: es Saf-Saf (2752), 18/04, (FI003471); C.: Lamluda macchia (2749), 09/04, (FI003467); C., Apollonia: 1.d. Rgua (2750), 11/04, (FI003469); C., Uadi el Kuf: fra Gasr Beni Gdam e Sidi Abd el Uahed, (2751), 11/04, (FI003468); C., el Gubba: Siret-Bettamer (2748), 7/4/1933. Leg. R. Pampanini (FI003466).

Cirenaica, Cirene: es Saf-Saf (2753), 21/04, (FI003470); C., el Beda: Uadi El Kuf: 1.d. Bu Breica (2756), 27/04, (FI003474); C., el Beda: Uadi Messaf-Saf, Ain Legmeila (2754), 22/04, (FI003472); C., el Beda: Uadi Beregt (2755), 24/04, (FI003473); C., el Beda: Uadi Uardama (2757), 02/05, (FI003475); C., Cirene: Uadi Hofra ( 2758), 05/05, (FI003476); C., Cirene: Uadi Bu Nabeh (2759), 15/5/1934. Leg. R. Pampanini \& R.E.G. Pichi Sermolli, (FI003477).

Accepted name: Ranunculus cyclocarpus Pamp. see Dobignard \& Chatelain 5: 193. 2013 and also Fl. Lib. 108: 43. 1984.

Note: this is a Libyan endemic limited to Cyrenaica and in particular to the area of the Akhdar Jebel, the chain that stretches from Barce (to the west) almost as far as Derna (to the East). Specimen no. 2748 is accompanied by a piece of newspaper with the note, handwritten by Pampanini, "Ranunculus sp. nov."

New taxon: Ranunculus flabellatus var. amphicarpus Pamp. in Arch. Bot. XII(1): 25. (1936a); Rend. Sem. Fac. Sc. Univ. Cagliari VIII(3): 65. (1938).

Original Collection: Libia, Cirenaica, Cirene: Saf-Saf 1933; C.: Slonta, steppa sassosa, (sub R. flabellatus f. amphicarpa) 17/04/1933. Leg. R. Pampanini (FI, only the 2nd specimen).

Accepted name: Ranunculus paludosus var. amphicarpus (Pamp.) Boulos comb. nov. (see Boulos 1979a).

Note: this specimen (Cirene: Saf-Saf 1933) is not present in FI, whilst there is another specimen: Cirenaica, Slonta, steppa sassosa (2744), 17/04/1933. Leg. R. Pampanini, corresponding to the apparently unpublished description in the protologue (Pampanini 1936a). We say "apparently" because of the uniqueness of the specimen Pampanini mentions (1938) and the fact that the specimen bears the usual piece of newspaper with the name of the new taxon (although under a different rank - f. amphicarpica Pamp.). Probably the name on the label is the first provisional hypothesis of the new taxon.

Thus it is probable that Pampanini wished to refer to this specimen and not the one published (may be with mistaken locality, but next to the one quoted on the label) in Pampanini (1938). Considering the margin of doubt that remains, we have not gone ahead with typification. 


\section{Rhamnaceae (M. Thiv)}

New taxon: Rhamnus alaternus f. intermedia Pamp. in Arch. Bot. XII(1): 36. 1936; Rend. Sem. Fac. Sc. Univ. Cagliari VIII(3): 70. (1938).

Type: Libia, Cirenaica, Messa a ovest di Cirene: Uadi Tmista (4812), 29/04/1934. Leg. R. Pampanini \& R.E.G. Pichi Sermolli, (FI003747, Lectotypus designated here).

Accepted name: Rhamnus alaternus L.

Note: Pampanini (1936) did not indicate a type specimen in his description of the taxon. In accordance with ICN Art. 40.1 and 9.11 (McNeill \& al. 2012) a lectotype is selected here. This specimen has a piece of newspaper with the name of the new taxon handwritten in blue pencil by Pampanini. It therefore very likely represents the material on which the description is based on.

New taxon: Rhamnus alaternus var. microphylla Pamp. in Arch. Bot. XII(1): 36. 1936; Rend. Sem. Fac. Sc. Univ. Cagliari VIII(3): 70. (1938).

Type: Libia, Cirenaica, Fra El Garib e Tolmeta: Uadi el Fahaga (4813), 14/04/1933. Leg. R. Pampanini, (FI003748, Lectotypus designated here).

Accepted name: Rhamnus alaternus L.

Note: the same points as shown for the nomenclatural treatment of Rhamnus alaternus $\mathrm{f}$. intermedia also apply to Rhamnus alaternus var. microphylla.

New taxon: Rhamnus pendula Pamp. in Arch. Bot. XII(1): 36. 1936; Rend. Sem. Fac. Sc. Univ. Cagliari VIII(3): 70. (1938).

Type: Libia, Cirenaica, El Beda, U. Msuria (4859), 10/05/1934; leg. Pampanini \& R.E.G. Pichi Sermolli, (FI003750, Lectotypus designated here).

Isolectotypus: ULT (non vidi).

Other original material: Cirenaica, Apollonia: U. Scechaba (4858), 01/05/1934, (FI003749); Cirene: U. BuNabeh (4860), 15/05/1934. leg. R. Pampanini \& R.E.G. Pichi Sermolli, (FI003751).

Accepted name: Rhamnus alaternus L.

Note: in the original description no type material was indicated. In Jafri S.M.H., Fl. Lib. 30: 9. (1977c) specimen no. 4859 is selected as type, kept in two Herbaria (FI and ULT). In FI there is also the unpublished specimen but part of the original collection: Cirene: U. Belgadir (4857), 26/04/1934. Leg. R. Pampanini \& R. E. G. Pichi Sermolli, unpublished. According to preliminary molecular analyses, $R$. pendula is distinct from other $R$. alaternus accessions. This taxon is, however, nested within the $R$. alaternus group. Therefore, until molecular studies are completed, $R$. pendula is here regarded as a synonym of $R$. alaternus.

New taxon: Rhamnus tripolitana Engler, in Pflanzenw. Afr. iii, II (Engl. \& Drude, Veg. Der Erde, ix.) 311 (1921).

Type: [Libya], Tripolitanien, [Tripoli]: Qasr Safran (928), 23/4/1881. Leg. G. A. A. Krause, (FI001177, Lectotypus designated here).

Accepted name: Rhamnus tripolitana Engler

Note: Engler (1921) states a close relationship between $R$. tripolitana and $R$. alaternus because of their racemose inflorescences. This shrub is moreover characterised by 1.5 - 
$2 \times 1-1.5 \mathrm{~cm}$, elliptic leaves which are yellowish-tomentose on the lower surface. According to a letter from Diels to Pampanini, the specimen housed at FI is a fragment of the type of $R$. tripolitana. This specimen at FI seems to be the only original material of this taxon because the specimen at B is likely destroyed (R. Lücking in litteris 2016). The material at FI is, however, too sparse to infer the taxonomic status of $R$. tripolitana. Therefore, it is refrained from drawing conclusions.

\section{Rosaceae (K. Pagitz)}

New taxon: Rubus cyrenaicae Hruby in Arch. Bot. XII(1): 28-29. (1936a); Rend. Sem. Fac. Sc. Univ. CagliariVIII(3): 67. (1938).

Type: Lectotypus: Libia, Cirenaica: U. Derna, 12/051934 (3413), R. Pampanini \& R.E.G. Pichi Sermolli, sub. " $R$. cyrenaicus, Hruby 232”, (FI003453) by E. Monasterio-Huelin \& H. E. Weber, in: Edinb. J. Bot. 53 (3): 316 (1996).

Syntypi: L.: Cirenaica, Cirene: Uadi Belgadir (3411), 26/04, (FI003454); C.: Uadi Hofra (3412), 05/05/1934. leg. R. Pampanini \& R.E.G. Pichi Sermolli (FI003455).

Accepted Name: Rubus ulmifolius Schott var. anoplothyrsus Sudre

Note: Rubus cyrenaicae Hruby is part of R. ulmifolius Schott, and a synonym of Rubus ulmifolius var. anoplothyrsus Sudre [see E. Monasterio-Huelin \& H. E. Weber in: Edinb. J. Bot. 53 (3): 311-322 (1996)]. The designated lectotype includes two inflorescences, both syntypi display only vegetative parts. All the specimens show autographic slips by Hruby, one of the syntypi also a second by Pampanini. The specimens originate from all three sites listed in Rend. Sem. Fac. Sc. Univ. Cagliari VIII(3): 67. (1938).

New Taxon: Rubus mussolinii Hruby (= R. cyrenaicae $\times$ ulmifolius) in Arch. Bot. XII(1): 29. (1936a); Rend. Sem. Fac. Sc. Univ. Cagliari VIII(3): 67. (1938).

Original material: Libia, Cirenaica, el Beda: Uadi Messaf-saf 1933-34. Leg. Pampanini \& R.E.G. Pichi Semolli.

Note: the original material of this taxon is probably lost. Description and the mentioned hybrid-status ( $R$. ulmifolius $\times$ R. cyrenaicae, the latter is also R. ulmifolius) indicate that this taxon belongs also to Rubus ulmifolius Schott.

New Taxon: Rubus mussolinii (= R. cyrenaicae $\times$ ulmifolius) f. cuneatiformis Hruby in Arch. Bot. XII(1): 29. (1936a); Rend. Sem. Fac. Sc. Univ. Cagliari VIII(3): 67. (1938).

Type: Libia, Cirenaica, el Beda: U. Messaf-saf Ain Legmeila, 22/04/1934 (3414), Pampanini \& R.E.G. Pichi Sermolli, (FI003451, Lectotypus designated here).

Isolectotype: (FI003452).

Accepte name: Rubus ulmifolius Schott.

Note: Rubus mussolinii Hruby f. cuneatiformis Hruby is part of Rubus ulmifolius Schott; on the sheet of the Lectotypus there are two autographic slips by Hruby (at the bottom, on the left), and by Pampanini (in blue pencil). On the Isolectotype an autograph is missing, but it is obviously part of the same collection. Rubus mussolinii f. cuneatiformis is documented from the locus classicus only.

New Taxon: Rubus mussolinii (= R. cyrenaicae $\times$ ulmifolius) f. pseudanisodon Hruby in Arch. Bot. XII(1): 29. (1936a); Rend. Sem. Fac. Sc. Univ. Cagliari VIII(3): 67. (1938). 
Type: Libia, Cirenaica, el Beda - U. Msuria, 10/05/1934 (3415). Leg. Pampanini \& R.E.G. Pichi Sermolli, (FI003450, Lectotypus designated here).

Accepted name: Rubus ulmifolius Schott.

Note: Rubus mussolinii Hruby f. pseudanisodon Hruby is part of Rubus ulmifolius Schott; on the sheet of the Lectotypus there are two autographic slips by Hruby (at the bottom, on the left), and by Pampanini (by blue pencil). The text by Hruby indicates $R$. cyrenaicae $\times$ anisodon $\mathrm{f}$. bastardianus Sudre. Rubus anisodon is one of Sudre's valueless microspecies of $R$. ulmifolius (Sudre 1908-1913, Rubi Europae, p. 71 f.). Rubus mussolinii Hruby f. pseudanisodon Hruby is written in blue by Pampanini on a separate label. The herbarium specimen originated from the only site documented for this taxon.

New Taxon: Rubus mussolinii f. repens Hruby $(=R$. supercyrenaicae $\times$ ulmifolius var. anisodon) in Arch. Bot. XII(1): 29-30. (1936a); Rend. Sem. Fac. Sc. Univ. Cagliari VIII(3): 67. (1938).

Type: Libia, Cirenaica, el Beda: U. Urdama, 02/05/1934 (3416). Leg. Pampanini \& R.E.G. Pichi Sermolli, (FI003416, Lectotypus designated here).

Accepted name: Rubus ulmifolius Schott.

Note: Rubus mussolinii Hruby f. repens Hruby is part of Rubus ulmifolius Schott; on the sheet of the Lectotypus there are two autographic slips by Hruby (at the bottom, on the left), and by Pampanini (in blue pencil). Initially Hruby wrote Rubus mostarensis Sudre $(=R$. ulmifolius $\times$ sanctus $)$, then he replaced sanctus by cyrenaicae f. repens Hruby. Rubus mussolinii Hruby f. repens Hruby is written in blue by Pampanini on a separate label. The herbarium specimen originates from the only site documented for this taxon.

New Taxon: Rubus mussolinii f. vulgatiformis Hruby in Rend. Sem. Fac. Sc. Univ. CagliariVIII(3): 67. (1938).

Type: Libia, Cirenaica, Cirene: U. Bu Nabeh, 15/05/1934 (3417). Leg. Pampanini \& R.E.G. Pichi Sermolli, (FI003448, Lectotypus designated here).

Accepted name: Rubus ulmifolius Schott

Note: Rubus mussolinii Hruby f. vulgatiformis Hruby is part of Rubus ulmifolius Schott; on the sheet of the Lectotypus there are two autographic slips by Hruby (at the bottom, on the left), and by Pampanini (in blue pencil). Initially Hruby wrote anisodon $\times$ sanctus, then he replaced this by $R$. mussolinii Hr. (= ulmifolius $\times$ cyrenaicae $) \mathrm{f}$. vulgatiformis, which is also written in blue by Pampanini on a separate label.

New Taxon: Rubus pampaninii Hruby (= R. cyrenaicae $\times$ sanctus) in Arch. Bot. XII(1): 30. (1936a); Rend. Sem. Fac. Sc. Univ. CagliariVIII(3): 67. (1938).

Original material: Libia, Cirenaica, Cirene: Uadi Belgadir 1934. Leg. R. Pampanini \& R.E.G. Pichi Sermolli.

Note: the original material of this taxon is probably lost. The description is not detailed enough to allow a confident classification. The taxon is most likely part of R. ulmifolius or a segregate of it.

New Taxon: Rubus pampaninii (= R. cyrenaicae $\times$ sanctus $)$ f. fissidens Hruby in Arch. Bot. XII(1): 30. (1936a); Rend. Sem. Fac. Sc. Univ. Cagliari VIII(3): 67. (1938). 
Type: Libia, Cirenaica, Cirene: U. Begadir, 26/04/1934 (3418). Leg. Pampanini \& R.E.G. Pichi Sermolli, (FI003446, Lectotype designated here).

Accepted name: Rubus ulmifolius Schott

Note: on the sheet of Lectotypus there are two autographic slips by Hruby (at the bottom, on the left), and by Pampanini (in blue pencil).

New Taxon: Rubus pampaninii (= R. cyrenaicae $\times$ sanctus) f. subvestitus Hruby in Arch. Bot. XII(1): 30. (1936a); Rend. Sem. Fac. Sc. Univ. Cagliari VIII(3): 67. (1938).

Type: Libia, Cirenaica, Cirene: U. Bu Nabeh, 15/05/1934 (3419). Leg. Pampanini \& R.E.G. Pichi Sermolli, (FI003447, Lectotype designated here).

Accepted name: cfr. Rubus ulmifolius Schott

Note: the herbarium specimen is rather inadequate. The taxon is most likely part of R. ulmifolius. On the sheet of Lectotypus there are two autographic slips by Hruby (at the bottom, on the left), and by Pampanini (in blue pencil).

\section{Rubiaceae (E. Vela)}

New taxon: Asperula cyrenaica f. hispidula Pamp. in Arch. Bot. XII(1): 45. 1936; Rend. Sem. Fac. Sc. Univ. Cagliari VIII(3): 76. (1938).

Type: Libia, Cirenaica: fra Gubba e l'Uadi el Atrun: 1.d. Argub Gazal (7599), 14/05/1934. Leg. R. Pampanini \& R.E.G. Pichi Sermolli, (FI003732, Lectotypus designated here).

Syntypus from the original collection: Cirenaica: Apollonia: Uadi Scechaba (7598), 01/05, (FI003731).

Accepted name: Asperula cyrenaica (E.A. Durand \& Barratte) Pamp. (by Dobignard A. \& Chatelain C., In: Index Synon. Fl. Afr. N. 5: 254. 2013).

Note: forma hispidula is part of the variation of the species, but this variation does not overlap the variation of the "rather variable species" (Jafri S. M. H. In: Flora of Libya, 65: 30. 1979) A. hirsuta Desf. sensu stricto from Morocco, Algeria and Tunisia.

New taxon: Asperula cyrenaica f. villosa Pamp. in Arch. Bot. XII(1): 45. 1936; Rend. Sem. Fac. Sc. Univ. Cagliari VIII(3): 76. (1938).

Type: Libia, Cirenaica, Uadi El Kuf: fra Gasr Beni Gdam e Sidi Abd el Uahed (7601), 11/04/1933. Leg. R. Pampanini, (FI003734, Lectotypus designated here).

Syntypus from the original collection: Libya, Cirenaica, Uadi el Kuf: fra Gasr Beni Gdam e Sidi Abd el Uahed (7600), 06/04/1933, (FI003733, Leg. R. Pampanini).

Accepted name: Asperula cyrenaica (E.A. Durand \& Barratte) Pamp. (by Dobignard A. \& Chatelain C. in: Index Synon. Fl. Afr. N. 5: 254. 2013).

Note: forma villosa is part of the variation of the species, but this variation does not overlap the variation of the "rather variable species" (Jafri S. M. H. in: Flora of Libya, 65: 30. 1979) A. hirsuta Desf. sensu stricto from Morocco, Algeria and Tunisia.

New taxon: Putoria calabrica f. lactea Pamp. in Arch. Bot. XII(1): 45. 1936; Rend. Sem. Fac. Sc. Univ. Cagliari VIII(3): 76. (1938).

Type: Libia, Cirenaica, Messa a ovest di Cirene: Uadi Tmista (7666), 29/04/1934. Leg. R. Pampanini \& R.E.G. Pichi Sermolli, (FI003685, Lectotypus designated here). 
Accepted name: Plocama calabrica (L. f.) M. Backlund \& Thulin (by Dobignard A. \& Chatelain C. in: Index Synon. Fl. Afr. N. 5: 269. 2013.).

Note: although the white flowered form is only known from Cyrenaica, it can appears mixed with the typical pink flowered form in a same locality (cf. "c. $5 \mathrm{~km}$ from Susa, on way from Shahat", S.I. Ali 770 (ULT), S. I. Ali 771 (ULT); in Jafri 1979, Flora of Libya 65: 4 and should be considered as an individual achromatic form.

\section{Rutaceae (G. Domina)}

New taxon: Haplophyllum vermiculare var. cyrenaicum Pamp. in Nuovo Giorn. Bot. Ital. 24: 147. (1917)

Type: Cirenaica: Raaba (78), 04/[19]15, Leg. V. Zanon (FI, Lectotypus designated here).

Other syntypi from the original collection: C.: Sciallabi el Bebas (304), 24/02; C.: Giuliana, Forte (406), 04/06; C.: Raaba (641),07/06; C.: Cimitero Nuovo (643), 07/06/1916, Leg. V. Zanon (all material in FI).

Accepted name: Haplophyllum tuberculatum (Forsk.) Juss.

Note: the printed herbarium labels bring the handwriting by Pampanini. The field labels bring the handwriting by Zanon. The herbarium specimens are slightly morphologically different; the specimen that better fits the original description is designated as Lectotypus.

New taxon: Haplophyllum vermiculare var. cyrenaicum f. latifolium Pamp. in Nuovo Giorn. Bot. Ital. 24: 148. (1917)

Type: Holotypus: [Libya], Cirenaica: Raaba (642), 7 giugno 1916. Leg. V. Zanon (FI001166).

Accepted name: Haplophyllum tuberculatum (Forsk.) Juss.

Note: the herbarium labels are handwritten by Pampanini.

\section{Santalaceae (P. Cuccuini \& C. Nepi)}

New taxon: Thesium erythronicum Pamp. in Arch. Bot. XII(1): 22-23. (1936a); Rend. Sem. Fac. Sc. Univ. Cagliari VIII(3): 64. (1938).

Type: Libia, Cirenaica: Uadi el Atrum (1824), 14/05/1934. Leg. R. Pampanini \& R.E.G. Pichi Sermolli, (FI003694, Lectotypus designated here).

Isolectotypus: K000431436.

Syntypus from the original material: Libia, Cirenaica, Beda: 1.d. Sfeiat (1823), 04/05/1934. Leg. R. Pampanini \& R.E.G. Pichi Sermolli, (FI003695).

Accepted name: Thesium erythronicum Pamp. by Jafri S.M.H. In: Fl. Lib. 14: 2. 1977d; also in Dobignard \& Chatelain 5: 283. 2013.

Note: only specimen 1824 is mentioned in Pampanini (1936a), but both are cited in Pampanini (1938).

\section{Scrophulariaceae (M. Abuhadra \& P. Cuccuini)}

(The genera Antirrhinum and Linaria are placed in Plantaginaceae by Dobignard \& Chatelain 2013).

New taxon: Antirrhinum gebelicum Brullo \& Furnari in Webbia 34(1): 168. (1979). 
Type: Isotypus: Cirenaica: Uadi el Cuf, 1/05/1974. Leg. S. Brullo \& F. Furnari (FI). Holotypus (CAT).

Accepted name: Antirrhinum gebelicum Brullo \& Furnari

Note: as Antirrhinum tortuosum Bosc. ex Vent. in Dobignard \& Chatelain 5; 71. 2013.

New taxon: Antirrhinum tenue Viv. in Fl. Lib. specimen, 33, tab. XVI, fig. 5 and 6. 1824. Type: "In tumulis arenosis Magnae Syrteos", [leg. P. Della Cella, see note], in Viviani, Florae libycae specimen: tab. XVI, fig. 5, 6 (Lectotypus designated here), (Fig. 2).

Epitypus: Tunisia: in incultis Sfax, 02/06/1854, Kralik, Pl. Tunet. $\mathrm{n}^{\circ} 118$ (sub. Linaria viscosa Dum., FI-W).

Isoepitypi: K, P.

Accepted name: Linaria tenuis (Viv.) Spreng. see Viano (1978a), Sutton (1988), Dobignard \& Chatelain 5: 95. 2013.

Note: P. Della Cella collected plants in Libya (from Tripoli to western border of Egypt) in 1817 and delivered the complete collection to Prof. D. Viviani from Genova to be studied. With regard to Linaria tenuis (Viv.) Spreng, Viano (1978) states that the typus for the taxon is held in FI, but there is no trace of it there. Viano adds that Murbeck, in 1898, had already proposed a Neotypus (Tunisia: in incultis Sfax, 02/06/1834, Kralik, PI. Tunet. no: 118) conserved in LD Herbarium, but again where it is not to be found (P. Frödén, in litteris 2016). Sutton (1988) had already reported other possible isoneotypes at $\mathrm{K}$ as seen by Murbeck (where on the contrary there is only a note written by a technician in pencil who cites it under the work by Murbeck) and subsequently found also in FI, K and P, the latter two sub Linaria viscosa Dum. Murbeck settled for this choice since he had judged the material Viviani described to be an immature and dwarf specimen of what was subsequently confirmed in nature, and this was cause of later incorrect interpretations by other botanists of the time. Since he had never been to Genova, where the material of Viviani was held (but no longer present because it was destroyed during the $2^{\text {nd }}$ World War), he had probably seen the drawing published in Viviani (1824) as well as read his work. It is not clear what material of Kralik Murbeck examined, since he neither declared it nor do any of the specimens carry any evidence of his revisions. However, in our opinion the choice Murbeck made is incorrect, as there still exists an element of the original collection. This is table XVI, fig. 5 and 6; $\mathrm{x}$-calyx; y -corolla, (actually for fig. 6 Viviani, in his work (1824) on page 33, says: "fig. 6 huius speciei varietas altera" without specifying anything else) where it is published as an essential part of the protologue for Antirrhinum tenue. However, the illustration is "ambiguous" as it refers to a juvenile phase of the species Viviani identified and is insufficient for the purpose of precise application of the name. For this reason, it is legitimate to designate the cited image as Lectotypus, supported by an auxiliary specimen as epitype, specified in the above mentioned Kralik specimen no. 118 held in FI-W, in as much the most suitable among those identified.

New taxon: Linaria fruticosa f. dentata Pamp. in Bull. Soc. Bot. Ital. (1-3): 15. (1914a); Pl. Tripol.: 206. (1914c).

Type: [Libya], Tripolitania, Tarhuna: Uadi Sart (1768), 27/03/1913. Leg. R. Pampanini. (Lectotypus designated here, FI005921). 


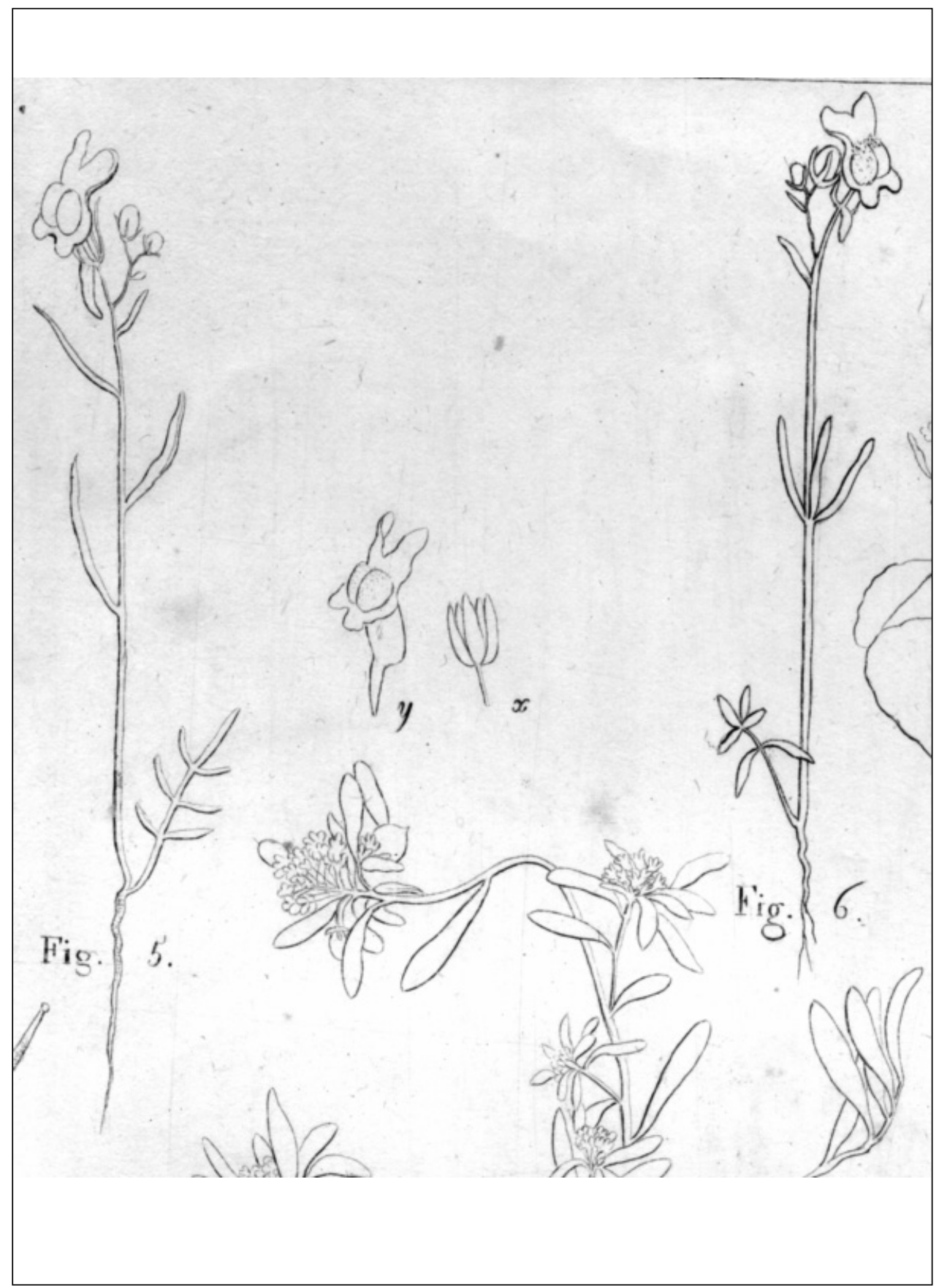

Fig. 2. Antirrhinum tenue Viviani, Figures 5 and 6, details x, y of table XVI, published in Florae Libycae specimen, 1824, Lectotypus, kept in Biblioteca di Scienze (Botanica), Università di Firenze. 
Other syntypus from the original collection: Tripolitania, Ta.: Ain Scersciara (713), 14/03/1913. Leg. R. Pampanini, (FI005908).

Accepted name: Kickxia aegyptiaca subsp. fruticosa (Desf.) Qaiser (by M. Abuhadra, in litteris 2013), also in Fl. Lib. 88: 65. 1982.

Note: Sutton (1988) cites all infraspecific L. fruticosa taxa only under: Microfiches 2: 118, but it is Wickens: 15. (1975) who gives all the Syntypi (Tarhuna, Pampanini 921; Garian, Pampanini 3862 \& 4138).

New taxon: Linaria fruticosa f. integrifolia Pamp. in Bull. Soc. Bot. Ital. (1-3): 16. (1914a); Pl. Tripol.: 206. (1914c).

Type: [Libya], Tripolitania, Tarhuna: Uadi Msaaba a Kasr Doga (921), 18/03/1913 . Leg. R. Pampanini, (FI005909, Lectotypus designated here).

Other syntypi from the original collection: Tripolitania, Garian: Uadi Garian (3862), 26/03, (FI005910); Ga.: Kasr Garian, nei campi incolti (4138), 30/04/1913. Leg. R. Pampanini, (FI005911).

Accepted name: Kickxia aegyptiaca subsp. fruticosa (Desf.) Qaiser (by M. Abuhadra, in litteris 2013), also in Fl. Lib. 88: 65. 1982.

Note: Sutton (1988) cites all infraspecific L. fruticosa taxa only under: Microfiches 2: 118, but it is Wickens: 15. (1975) who gives all the Syntypi (Tarhuna, Pampanini 921; Garian, Pampanini $3862 \& 4138)$.

New taxon: Linaria fruticosa var. litoralis Pamp. in Bull. Soc. Bot. Ital. (1-3): 16. (1914a); Pl. Tripol. : 206. (1914c).

Type: [Libya], Tripolitania, Tripoli: Gargadesc (25), 16/02/1913. Leg. R. Pampanini, (FI005912, Lectotypus designated here).

Other syntypus from the original collection: T., Tripoli.: Oasi di Zanzur (179), 23/02/1913. Leg. R. Pampanini.

Accepted name: Kickxia aegyptiaca (L.) Nabelek subsp. fruticosa (Desf.) Qaiser (by M. Abuhadra, in litteris 2013), also in Fl. Lib. 88:65. 1982 and in Dobignard \& Chatelain 5: 87. 2013.

Note: Sutton (1988) cites all infraspecific L. fruticosa taxa only under: Microfiches 2: 118, but it is Wickens: 15. (1975) who gives all the Syntypi (Tarhuna, Pampanini 921; Garian, Pampanini $3862 \& 4138)$.

New taxon: Linaria fruticosa f. villosa Pamp. in Pl. Tripol.: 206. (1914c).

Type: [Libya], Tripolitania, Tarhuna: Uadi Tenziua sul Ras Maader (2053), 01/04/1913. Leg. R. Pampanini, (FI005914, Lectotypus designated here).

Other syntypus from the riginal collection: T.-Tripoli: Aziza al Fonduc Scebani (4368), 09/05/1913. Leg. R. Pampanini (FI005915).

Accepted name: Kickxia aegyptiaca (L.) Nabelek subsp. fruticosa (Desf.) Qaiser (by M. Abuhadra, in litteris 2013), also in Fl. Lib. 88: 65. 1982 and in Dobignard \& Chatelain 5: 87. 2013.

Note: Sutton (1988) does not consider this infraspecific taxon of L. fruticosa. 
New taxon: Linaria haelava var. cyrenaica Pamp. \& Zanon in Nuovo Giorn. Bot. Ital. n.s. 26 (3): 216. 1919. (Ruhmer no. 256, 1883).

Type: [Libia], Cyrenaica: Bengazi (256), 07/01/1883. Leg. G. Ruhmer (sub. Linaria haelava Del.), (FI003729, Lectotypus designated here).

Other syntypus from the original collection: [Libya], Cirenaica, Bengasi: Sciallabi el Bebas, marzo 1918. Leg. V. Zanon (FI ?).

Accepted name: Linaria haelava var. cyrenaica Pamp. \& Zanon

Note: as Linaria laxiflora Desf. subsp. calcarlongum Qaiser in Fl. Lib. 88: 56. 1982, as Linaria haelava (Forssk.) Delile in Dobignard \& Chatelain. The specimen collected by Zanon is not kept in FI.

The taxon has moreover often been identified in the Cyrenaic area in all specialist works that look at this group of Linaria: in fact both S. Viano (1978b) and D. A. Sutton (1988) speak about it as a probable autonomous entity, already interpreted as a taxon described in the past as Antirrhinum laxiflorum var. angustifolium Viv. (Viviani, 1824), Fl. LIb.: 33. 1824, and Linaria haelava var. cyrenaica Pamp. \& Zanon, (Pampanini \& Zanon 1919), Nuovo Giorn. Bot. Ital. 26(3): 216. 1919. Only the rather brief description remains of the first, whilst the original material mentioned by the author still exists for the second. For that matter, in the Flora of Libya, Qaiser M. (1982) also considers L. haelava var. cyrenaica as a synomyn of a new taxon: $L$. laxiflora var. carcarlongum. But the protologue mentions the difference from the autonymic variety, which both Pampanini and Sutton had previously noted, i.e. : «..plants with filiform leaves, glabrous inflorescences with up to $4 \mathrm{~mm}$ pedicels and a longer spur than L. laxiflora [as in L. haelava] .... and also slightly under $1 \mathrm{~mm}$ long tuberculated seeds [as in L. haelava], grey-blackish in colour - [this last character is difficult to evaluate because the material tends to lighten towards brown when dry]. Moreover, Viviani in his description clearly speaks about a hairy inflorescence (..., calicibus hirsutis!), consequently only the name Pampanini gave fully interprets the characters which Viano and Sutton described from the specimens. Thus we are faced with a new taxonomic entity, that has apparently reached a certain stability, of an original L. haelava with some characters of L. laxiflora.

Sutton in his treatment (Sutton 1988) added further material for comparison, for the most part cases which well show these diagnostic characters. It is true that more recently such situations in nature have been considered as falling under the variability of L. haelava (Dobignard \& Chatelain 2013). On the contrary, we believe that the distribution shown by the material examined, and also confirmed indirectly by Qaiser, corroborates the validity of the varietal taxon Pampanini (1919) established as an endemic from North -West Cyrenaica.

New taxon: Linaria tarhunensis Pamp. in Bull. Soc. Bot. Ital. (1-3): 16. (1914a); Pl. Tripol.: 206 - 7. (1914c).

Type: Lectotypus: Tripolitania, Tarhuna: Uadi Tersiva, pianura a S. W. del Ras Maader (2079), 01/04/1913. Leg. R. Pampanini, FI005918 (by D. A. Sutton: 404. 1988).

Other Syntypi from the original collection: T, Tarhuna: Uadi Tenziua(Tersiva), nelle messi (1961), 01/04, (FI005917); T. Ta.: Abiar Milgha a Migi (4554), 28/02/1913. Leg. R. Pampanini, (FI005919). 
Accepted name: Linaria tarhunensis Pamp. (by D. A. Sutton: 404. 1988); also in: Fl. Lib. 88: 50, 52. 1982; and by M. Abuhadra, in litteris 2013.

Note: already in his publication regarding the new taxon, Pampanini fears some doubts about its rank and immediately after the binomial he points out in brackets: (An potius: L. fallax Coss. var. tarhunensis $m$ ?).

New taxon: Linaria tenuis var. laxiflora Pamp. in Bull. Soc. Bot. Ital. (1-3): 16. (1914a); Pl. Tripol. : 208. (1914c).

Type: Holotypus: [Libya], Tripolitania: Tripoli, Oasi di Tripoli ad Henni (3553), 23/04/1913. Leg. R. Pampanini. (FI).

Accepted name: Linaria tenuis (Viv.) Spreng. (by M. Abuhadra, in litteris 2013).

Note: Sutton mentions this taxon for Libya (Sutton: 432.1988), placing it under L. tenuis $L$. specifying “..Plants... with lax inflorescence...”, but he says also that its status had not yet been confirmed. The poor state of the material in our Herbarium (FI), even though it is the depository for the original collection, prevents us from analysing the problem more thoroughly.

New taxon: Scrophularia arguta f. albiflora Pamp. in Bull. Soc. Bot. Ital. (1-3): 16. (1914a); Pl. Tripol.: 209. (1914c).

Type: Holotypus: [Libya], Tripolitania, Tarhuna: Abiar Milgha a Migi (533), 28/02/1913. Leg. R. Pampanini, (FI005920).

Accepted name: Scrophularia arguta Soland. see Qaiser M. in Fl. Lib. 88: 3. (1982), by M. Abuhadra, in litteris 2013.

\section{Solanaceae (P. Cuccuini \& C. Nepi)}

New taxon: Hyoscyamus muticus subsp. brevibracteatus Corti in Nuovo Giorn. Bot. Ital. 45: 219. (1938).

Type: [Libya, Cyrenaica], Reg. di Auenát: letto del torrente che dalla cima di Auenát scende all'Uadi Abd el Málech, raro tra i 100e i 1400m., (1496) 19/4/1933. Leg. L. Di Caporiacco, (FI, Lectotypus designated here).

Other syntypus from the original collection: [Libya, Cyrenaica], Reg. di Auenát: Ultimo affluente di sinistra di Carcúr Brahim, salendo alla vetta principale, (1497), 02/ 1933. Leg. U. Monterin, (FI).

Accepted name: Hyoscyamus muticus $L$.

Note: Corti also alludes to another specimen collected by U. Monterin, which he believes can be attributed to this taxon. The doubt he expresses is due to the fact that the specimen is sterile: this is no. 1497 (the label inaccurately gives 1933, when it should be 1934, since Prof. Monterin guided a mission to the Libyan Sahara and Tibesti on behalf of the Italian Geographical Society in February-April, 1934).

New taxon: Solanum nigrum var. alatum f. robustum Pamp. in Arch. Bot. XII(1): 42. (1936a); Rend. Sem. Fac. Sc. Univ. Cagliari VIII(3): 75. (1938).

Type: Holotypus: Libia, Cirenaica, Cirene: Uadi Belgadir (7194), 26/04/1934. Leg. R. Pampanini \& R.E.G. Pichi Sermolli, (FI003730).

Accepted name: Solanum villosum Mill. subsp. villosum see Edmonds \& Chweya (1997). 
Note: as Solanum nigrum var. villosum L. in Fl. Lib. 62: 8-9. 1978; it should be noted that the hairs on the specimen do not have glands, see Edmonds \& Chweya (1997).

\section{Tamaricaceae (P. Cuccuini \& C. Nepi)}

New taxon: Tamarix pauciovulata var. micrantha Corti in Reale Soc. Geografica Italiana I: 191-192. (1942).

Type: [Libya], Fezzan occidentale, Reg. di Gat: Presso Féuet nella piana sabbiosa e sassosa fuori oasi (1533), 04/03/1934. Leg. R. Corti, (FI001178, Lectotypus designated here).

Isolectotypi: nos.1534-35. (FI).

Accepted name: Tamarix macrocarpa (Ehremb.) Bunge see Dobignard \& Chatelain 5: 245. 2013.

Note: the Lectotypus and specimens n. 1534-35 all have drawings and handwritten notes by Corti. For this taxon, Corti (1942) also mentions specimen no. 1558, which, as it is sterile, is attributed to the species s.l. All three specimens from the original collection are considered on the same level, since Corti designated them with different, progressive numbers for reasons linked to the collection and management of the material, as can be seen from the final typewritten labels where the number was added in pen later; as T. passerinoides Delile var. passerinoides in Fl. Lib. 66: 21. (1979).

\section{Valerianaceae (P. Cuccuini \& C. Nepi)}

New taxon: Centranthus calcitrapae f. albiflorus Pamp. in Bull. Soc. Bot. Ital. (1-3): 18. (1914a); Pl. Tripol.: 235. (1914c).

Type: [Libya], Tripolitania, Tarhuna: Abiar Milgha, sul Ras Ter (1068), 19/03/1913. Leg. R. Pampanini, (FI003736, Lectotypus designated here).

Other Syntypi from the original collection: Tripolitania, Mesellata.: Msid di Mesellata (2610), 9/04, (FI003739); T., Tarhuna.: Abiar Milgha, sul Ras Neb (1192), 19/03, (FI003737); Ta.: Abiar Milgha, a Migi (1029), 19/03, (FI003741); Ta.: Ras Ghenai (1540), 25/03, (FI003743); Ta.: Uadi Sart (1750), 27/03 (FI003738); Ta.: Uadi Sart (2132), 03/04, (FI003745); Ta.: Uadi Ksea sul Ras Argobinani (2451), 08/04, (FI003740); T., Garian: Ras Tecut (3706), 26/04, (FI003742); Ga.: Ras Bu Ganus (3943), 27/04, (FI003744); Ga.: Uadi Garian sul Ras Omcteba (4109), 29/04/1913. Leg. R. Pampanini, (FI003746).

Accepted name: Centranthus calcitrapae (L.) Dufr., see Richardson in Bot. J. Linn. Soc. 71(3): 231. (1975).

Note: specimen no. 2132, in Pampanini (1914a) is erroneously given as no. 2133. Richardson (1975), does not consider the taxon.

New taxon: Valerianella discoidea var. berenicea Pamp. in Arch. Bot. XII(1): 45. (1936a); Rend. Sem. Fac. Sc. Univ. Cagliari VIII(3): 76. (1938).

Type: Holotypus: Libia, Cirenaica: Giardina, tra Bengasi e Solluh (7791), 10/03/1933. Leg. R. Pampanini, (FI003735).

Accepted name: Valerianella chlorodonta Coss. \& Durieu (by H.N. Le Houerou, 16/07/1960), also Alavi S. A. in Fl. Lib. 46: 6-7. (1977). 


\section{Violaceae (P. Cuccuini \& C. Nepi)}

New taxon: Viola scorpiuroides var. inflata Pamp. in Bull. Soc. Bot. Ital.: 117. (1912).

Type: [Libya], Cirenaica: Derna, Ridotta "Piemonte", piani cespugliosi ed erbosi verso l’Halg Bu-Rues, 02/1912. Leg. M. Longa, (FI003808, Lectotypus designated here).

Isolectotypus: FI003807.

Accepted name: Viola scorpiuroides Coss., in Fl. Lib.13: 1. (1977e), also in Dobignard \& Chatelain 5: 352. (2013).

Note: the lectotypus has the original label handwritten by M. Longa, while the identification is signed by R. Pampanini. The label of the isolectotypus is handrwritten by R. Pampanini.

\section{Zygophyllaceae (P. Cuccuini \& C. Nepi)}

New taxon: Fagonia kahirina var. pseudocretica Pamp. in Arch. Bot. XII(1): 33-34. (1936a); Rend. Sem. Fac. Sc. Univ. Cagliari VIII(3): 69. (1938).

Type: Lectotypus: Libia, Cirenaica: El Gtafia a sud di Agedabia, [13/03/]1933, Pampanini no. 4565 (FI) [FI003902] (by El Hadidi, in Mitt. Bot. München 11: 393, fig 7, E. 1974.).

Accepted name: Fagonia scabra Forssk., in B-A. Beier 3(3): 251. 2005 and in Dobignard \& Chatelain 5: 358, 359. (2013).

Note: El Hadidi cites erroneously no. 4564 as the typus, whilst in actual fact it is no. 4565 . The typus was identified by M. N. El Hadidi (10/06/1972) as Fagonia sinaica Boiss. var. pseudocretica (Pamp.) Hadidi comb. nov. (= F. scabra Forssk.), see Bot. Not. 125(4): 531. 1972, Mitt. Bot. Munchen 11: 393, fig 7, E. 1974, and Fl. Lib. 38: 22. 1977. Dobignard \& Chatelain 5: 358. 2013, erroneously cite Fagonia pseudocretica Pamp. given when Pampanini actually described F. kahirina var. pseudocretica Pamp., see Arch. Bot. XII(1): 33-34. (1936a).

List of non-validly published names, according to article 24.3 of ICN (McNeill \& al. 2012), by R. Pampanini, material of which is held in FI.

\section{Orobanchaceae}

New taxon: Cistanche lutea f. genuina Pamp. in Arch. Bot. XII(1): 42. (1936a). Rend. Sem. Fac. Sc. Univ. Cagliari VIII(3): 75. (1938).

Original Collection: Cirenaica Umm er Rzem; Bomba; C.: Bomba: El Gefar; fra Bir Acheim e Mechili; Mechili: Uadi Ramla 1934. Leg. R. Pampanini \& R.E.G. Pichi Sermolli.

New taxon: Cistanche violacea f. genuina Pamp. in Arch. Bot. XII(1): 43. (1936a). Rend. Sem. Fac. Sc. Univ. Cagliari VIII(3): 75. (1938).

Original Collection: Cirenaica: Agheila; C.: Uadi Faregh: 1.d. Maaten Giofer; C.: fra Agedabia e Saunnu (? Fruct); C.: Saunnu; C.: fra Soluch e Sceleidima 1934. Leg. R. Pampanini \& R.E.G. Pichi Sermolli.

\section{Rubiaceae}

New taxon: Asperula cyrenaica f. genuina Pamp. in Arch. Bot XII(1): 45. (1936a); Rend. Sem. Fac. Sc. Univ. Cagliari VIII(3): 76. (1938).

Original Collection: Cirenaica, Beda: Uadi Scisu; C.: Uadi derna 1934. Leg. R. Pampanini \& R.E.G. Pichi Sermolli. 


\section{Conclusions}

The work is complete. This second part of the work "treats" 112 (113 if including the name of a new genus) new names considering all those validly published [therefore excluding any names falling under article 24.3 of the ICN (McNeill 2012]. Of these, once excluding those already subjected to nomenclatural studies, 91 ( +1 genus) have been typified; in two cases it was necessary to also provide two epitypes since the typi (images) were considered to be "ambiguous". It should also be remembered that we could not always designate types for reasons linked to the problematic availability of materials from the various original collections or for insufficient material at hand. Therefore, the catalogue $\left(1^{\text {st }}\right.$ and $2^{\text {nd }}$ part) considers a total of 353 new names, whilst 286 typifications have been carried out. Our study has examined a total of approximately 23,000 specimens, selecting about 1,500 from the original collections.

\section{Phyto-geographical Assessment}

With so many abundant collections at hand, we also attempted to estimate their phytogeographical value with respect to the areas Quézel considered in 1978. According to Quézel (1978) the Libyan territory covers from 8 to 13 of the phyto-geographical regions into which the French scholar divided North Africa. These are the A: North African Steppe, B: Cyrenian-Mediterranean, C: East African Steppe, D: North Saharan, E: North-East Saharan, and very marginally F: Central Saharan, G: High Mountain Saharan and H: South Saharan. As can be seen, Fig. (3) shows the presence of the investigated taxa, found in 6 out of the 8 mentioned regions. In particular, regions $\mathrm{B}$ and $\mathrm{A}$ are the most predominant, with C, E, D exhibiting important values in decreasing order, with sporadic occurrences in F. This distribution results not only from the geographical characteristics of the itineraries followed by the collectors of the specimens held in FI or studied there. It also stems from the floristic reality of Libya itself, thus confirming the representative value of the material taken as a whole (Cavara F. 1926; Corti R. 1942; Quézel 1978; Brullo \& Guglielmo 2001).

\section{Present taxonomical value}

During the revision of the first part of this work, we were asked to evaluate on the present taxonomical validity of the taxa considered in the work. Now that our work is complete, we feel we can give an answer. We took the work by Maire \& al. (1952-1987) as the starting point for our reply, since it homogeneously illustrates the area in which Libya lies. And as the reference for our final evaluation, we concentrated on the only Flora for that country, the "Flora of Libya" (Auctores vari 1977-1988), whilst for nomenclatural updating the work by Dobignard and Chatelain (2010-2013), as well, obviously, as individual updating or re-evaluation of individual taxon ensuing from these general works. For this investigation, see Tab. (1) in which data can be summed up as follows. Starting from the work by Maire, two thirds of the taxa are presented, in particular those of Pampanini, of which as many as 62 are recognised as good taxa (directly or under comb. or stat. nov.). The most recent treatments, the "Flora of Libya" and that by "Dobignard \& Chatelain", recognise 32 and 43 taxa respectively, again as such or under combinations or new status. To these a further 10 taxa may be added as a result of other recent investigations or revi- 


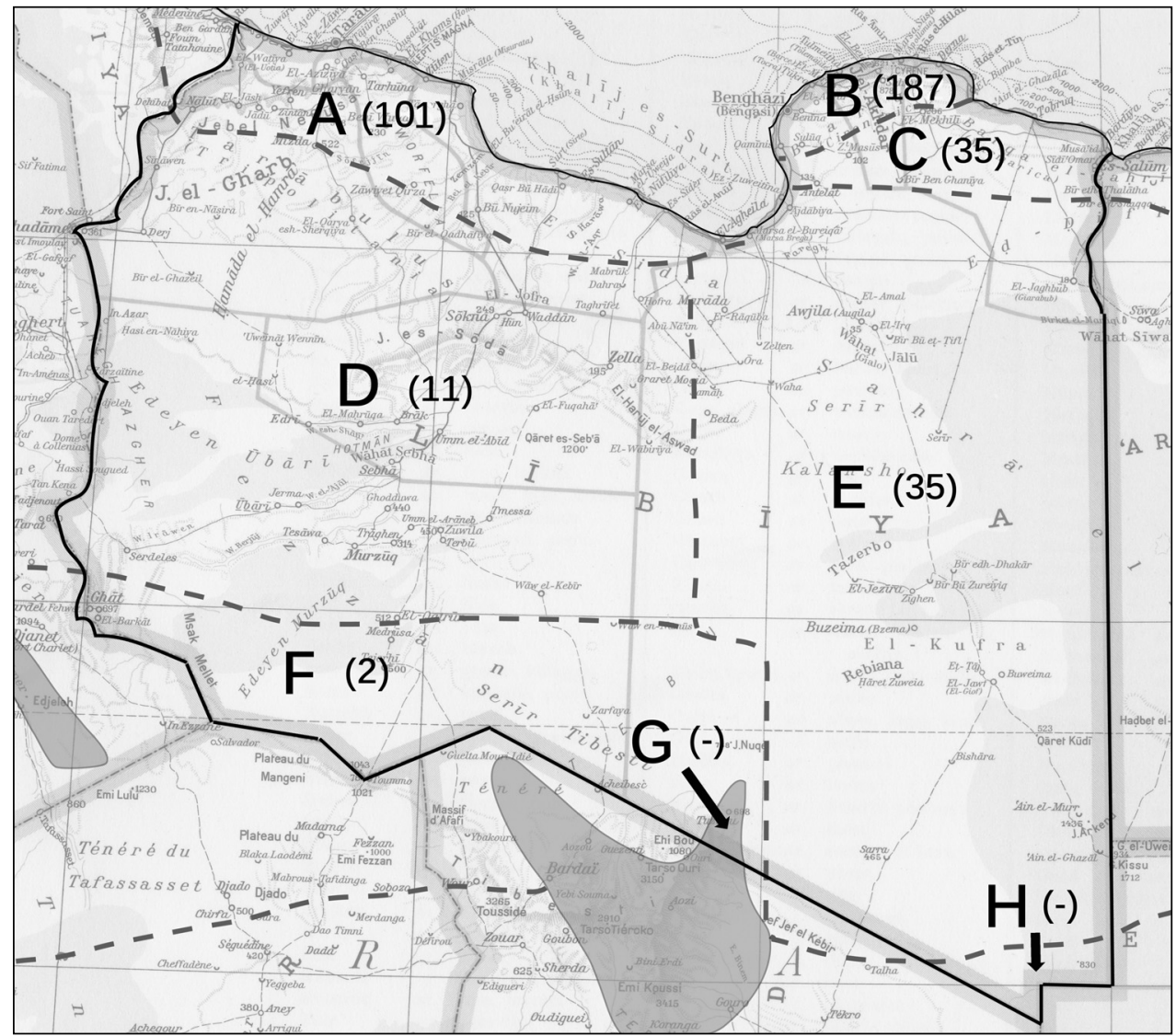

Fig. 3. Phytogeographical division of Libya in accordance with the domains set up by Quézel (1978) for Northern Africa. For each area, indicated by a letter, the number of detected types in this research $\left(1^{\text {st }}\right.$ and $2^{\text {nd }}$ part) is reported in round brackets. Rarely, when typification was not possible, the original materials are indicated. Legend: A: Steppic-Northern African Domain; B: Cyrenian-Mediterranean Domain ; C: Steppic-Eastern African Domain; D: Northern Saharan Domain; E: North-eastern Saharan Domain; F: Central Saharan Domain; G: Saharan-Hight Mountain Domain; H: Southern Saharan Domain.

sions. The latter are material which for the most part come from Cyrenaica (respectively $26,37,8)$ and secondly Tripolitania $(5,5,2)$. Only one taxon is for Fezzan $(1,1,-)$. These data faithfully reflect the proportions found from the material examined in the phytogeographical context. Considering this as a whole, we can say that this is due to the fact that Cyrenaica has historically been far more investigated, and to its multiple and peculiar morpho-ecological aspects that exalt its floristic wealth.

\section{Connections with the Collections}

As regards the collections, as well as the obvious prevalence of the material Pampanini collected himself (together with Pichi Sermolli for the 1934 Cyrenaica col- 


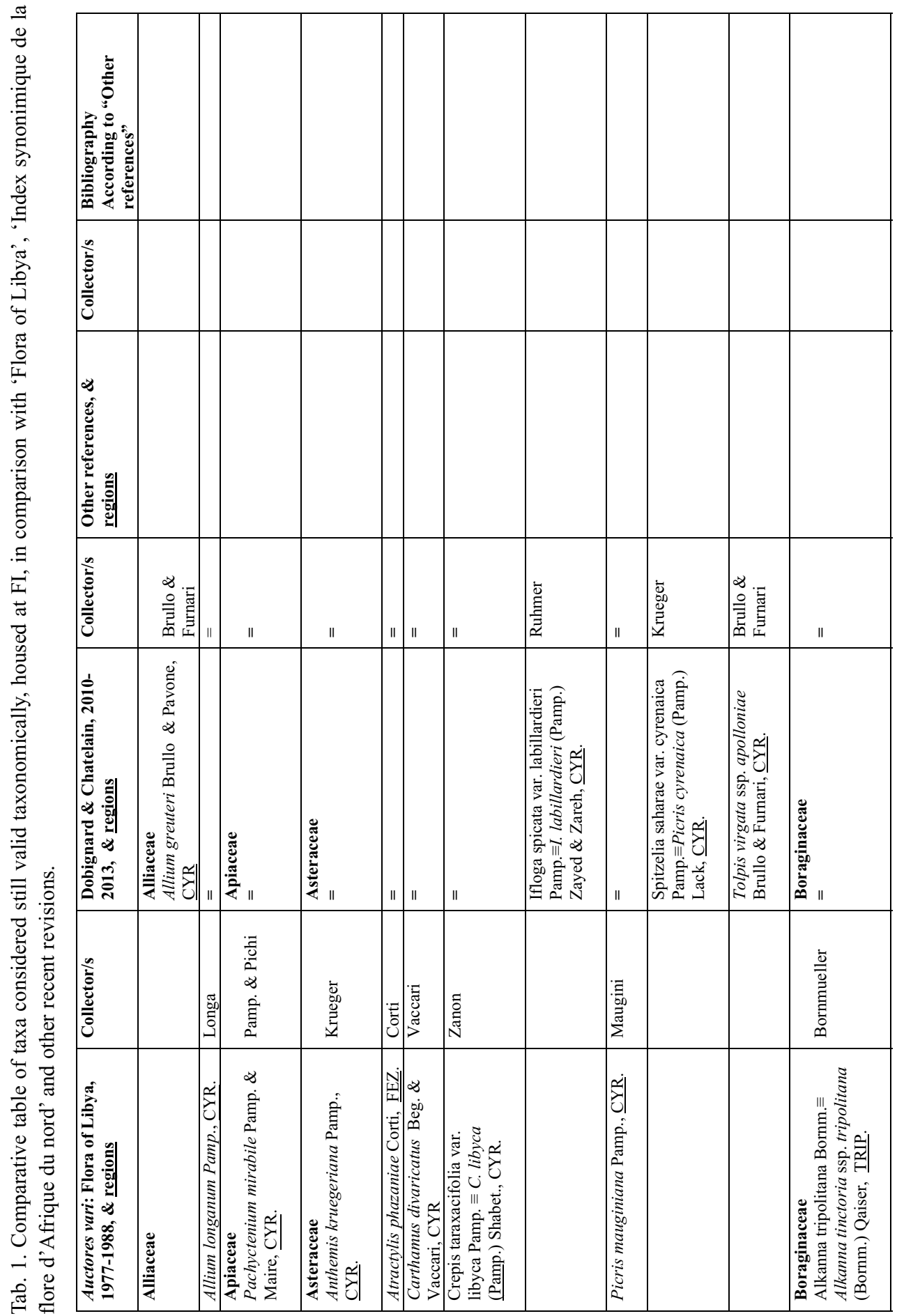




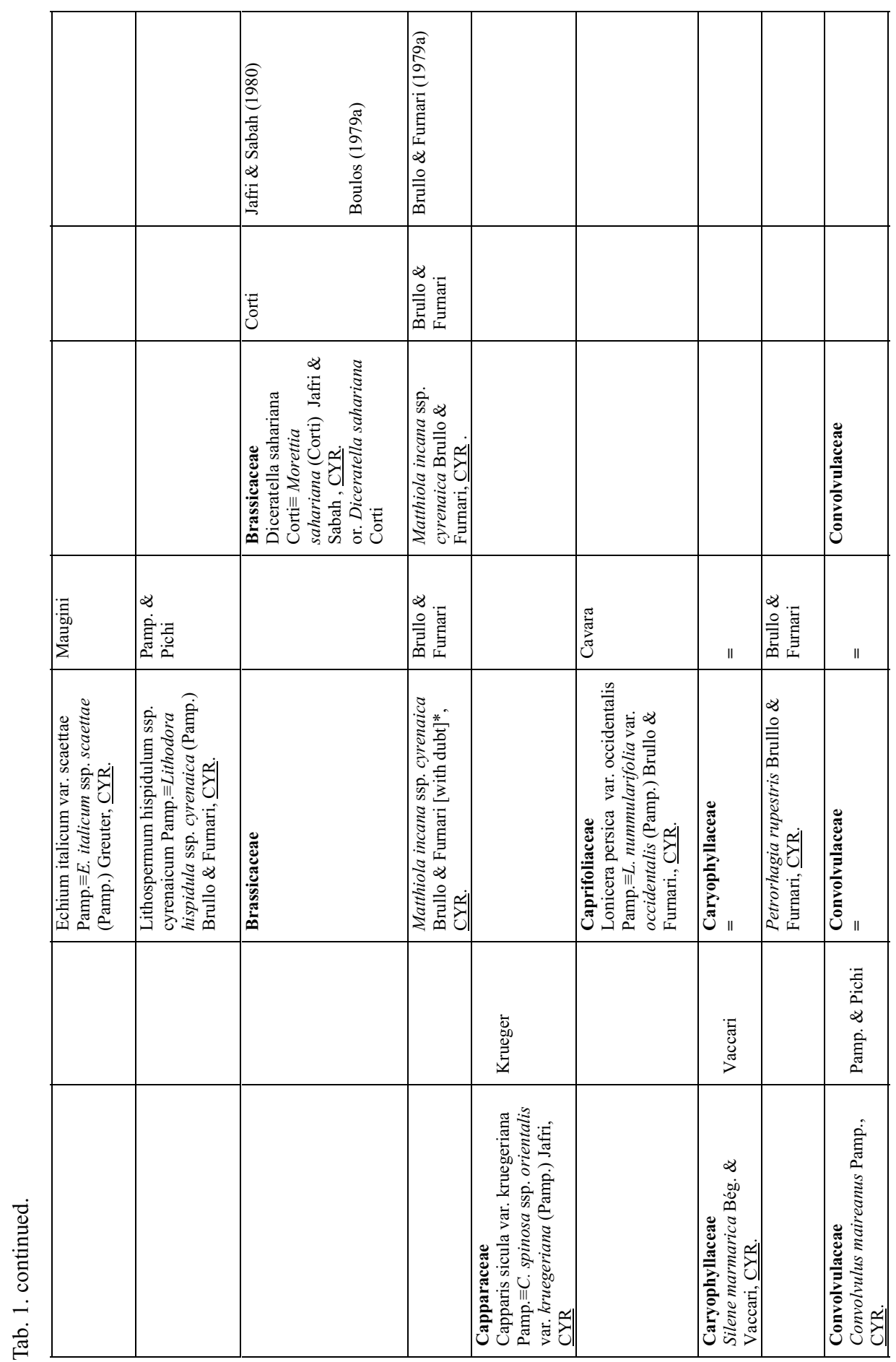


Flora Mediterranea 26 - 2016

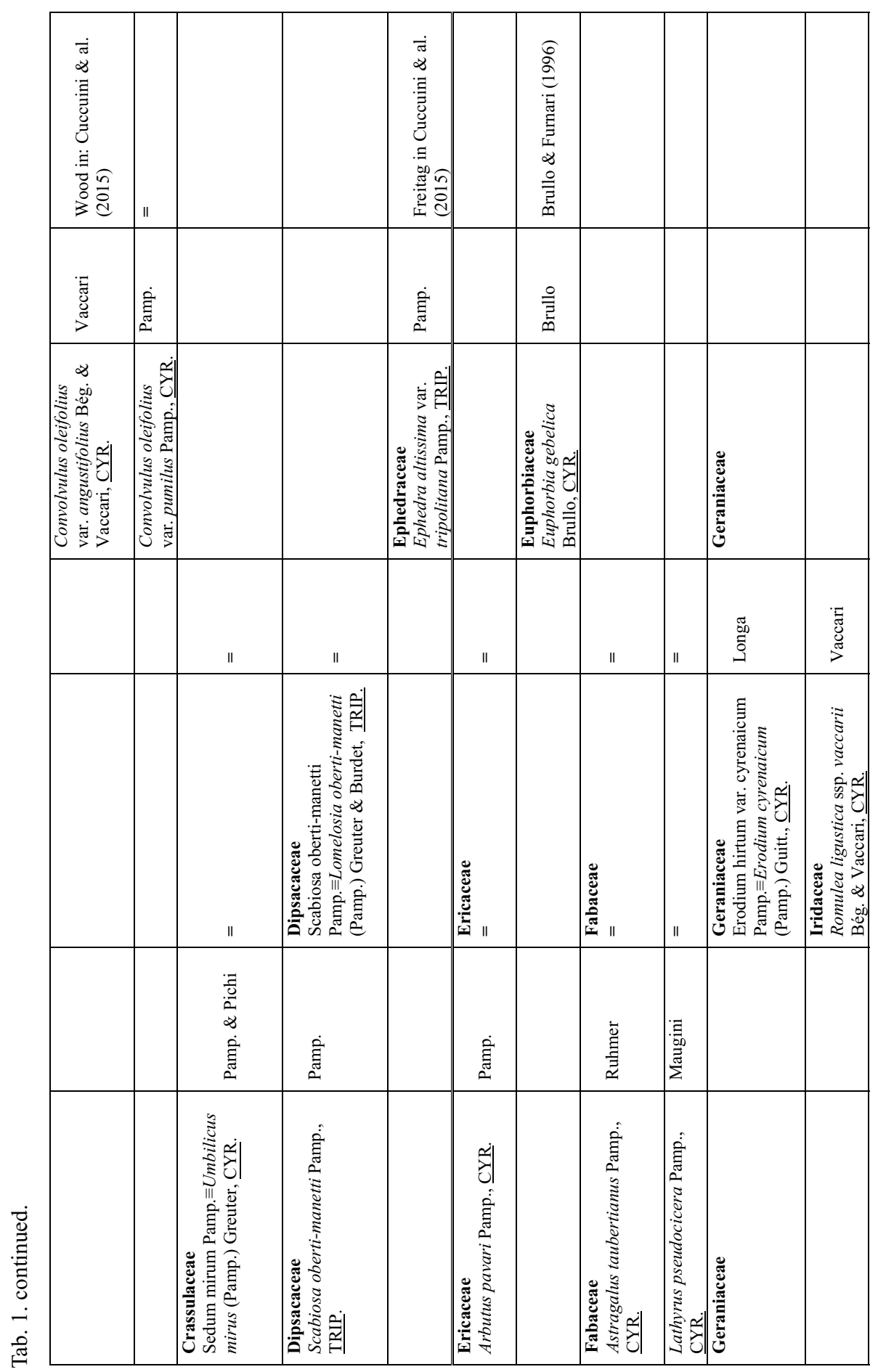




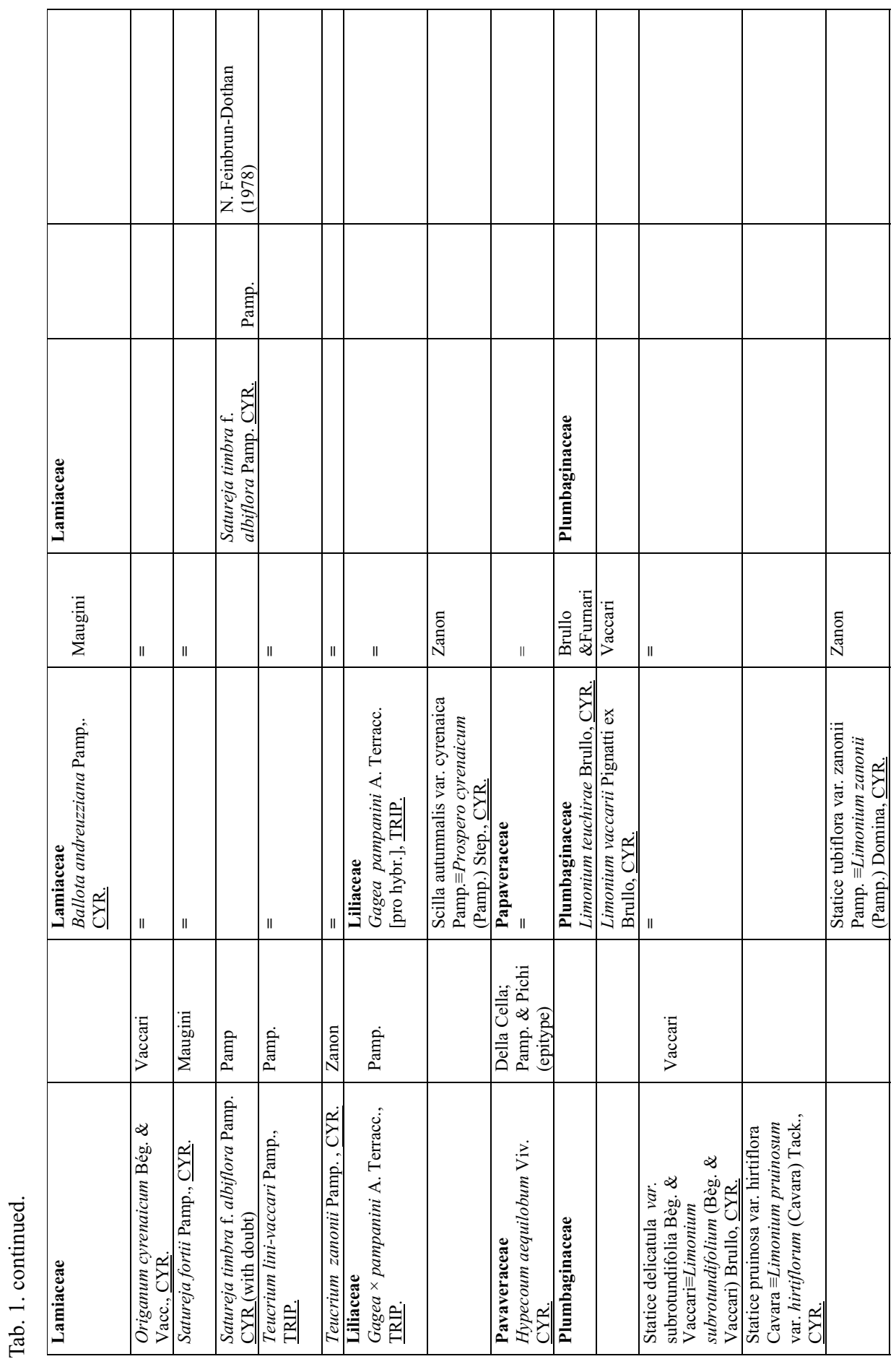




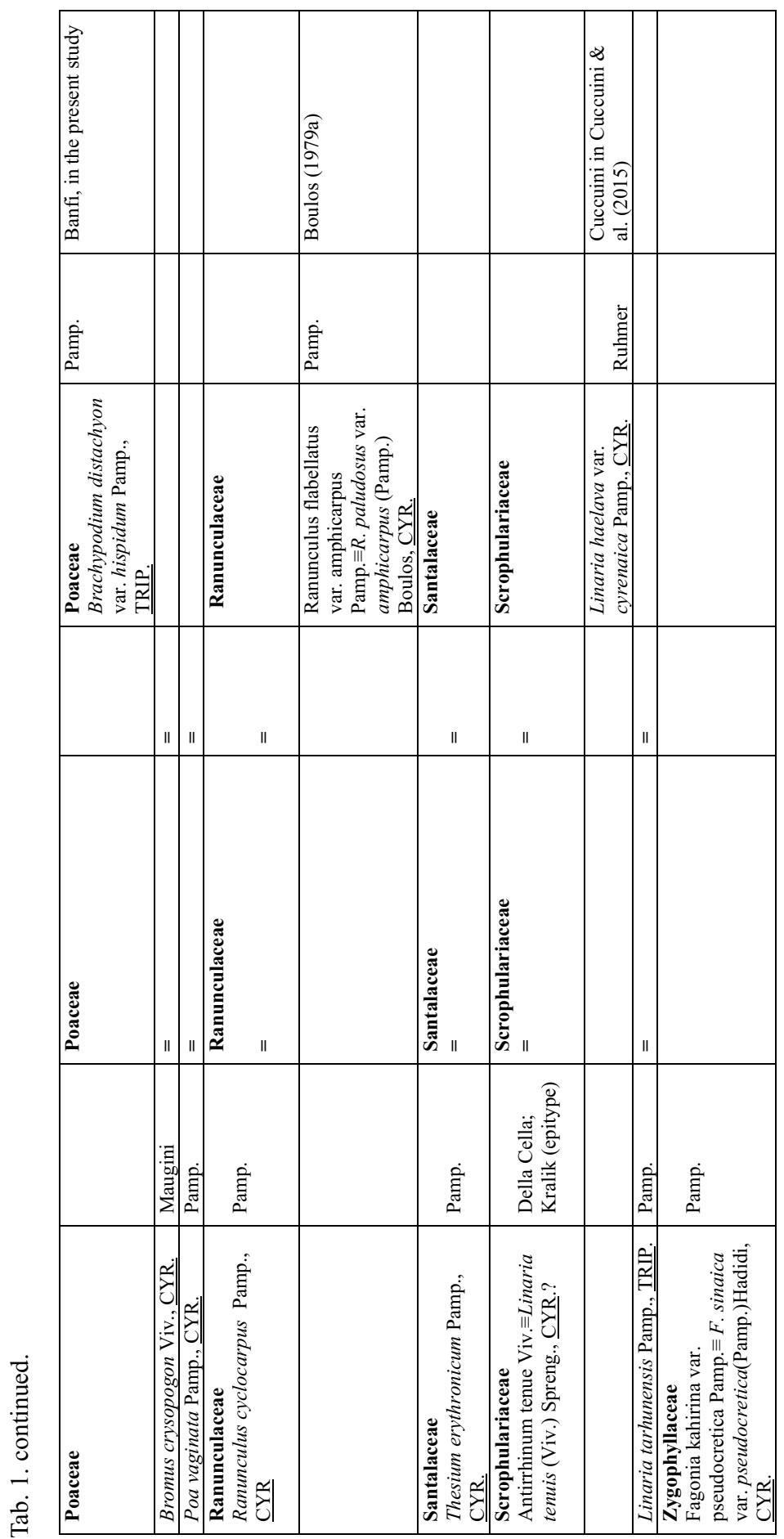


lection), the Zanon, Maugini and particularly Krueger collections also appear in the material he studied. These were essential for some parts of Cyrenaica, and the care and attentiveness can be seen in the new taxa described and in the number of those remaining accepted. Regarding other botanists, the taxa described by Corti for the Fezzan and Béguinot (but collected by A. Vaccari) for all north Libya deserve special mention. Finally, we must remember the older material of Ruhmer, which played an important part in typifications as well as the true historical pearls among the taxa of Viviani, Durand \& Barratte and Engler respectively, some of which still held accepted. Obviously, more recent collections are also important, such as those of Brullo and Furnari (in general, duplicates in FI), whose taxonomic validity was "helped" by their modernity, or those of Ricceri and Steinberg who assembled the last important Libyan collections held in FI. Thus we have an extremely varied panorama of collections which, taken as a whole, and starting from the original and precious "Erbario Libico" are a valuable research tool for the study of the Libyan Flora.

\section{Presence of specimens of R. Pampanini and R.E.G. Pichi Sermolli's collections in other Herbaria}

This short chapter describes the existence of Libyan collections in other Italian or foreign Herbaria, the originals of which are held FI. Only the main collection of the old 'Erbario Libico', that is the Pampanini collections, are considered.

From the existing bibliography (printed and on line), and in particular the Index Herbariorum (Thiers, B. [continuously updated] ed. on line), and Index HerbariorumCollectors (Vegter 1983), the records for Pampanini and Pichi Sermolli regarding Libya refer exclusively to FI, BR in Belgium and ULT in Libya. Furthermore, some herbaria web sites appear to refer to material from Cyrenaica (see Table 2). But the literature cited in the first part of this work (Cuccuini \& al. 2015), including unedited additional catalogues and, in this second part, exchanges (see the exchange records and indices for 1958-1969), mention that several sets of duplicates were made of the Tripolitania (1913) as well as the Cyrenaica collections (1933, 1934). It seems that no duplicates of the Tripolitania collections exist in other herbaria although, while studying them, Pampanini frequently contacted P, B and W herbaria. On the contrary, as far as the Cyrenaica collections are concerned, it seems that, thanks to Pichi Sermolli, who was custodian of both collections $(1933,1934)$ for a long period after the death of Pampanini, as many as 26 variously sized series of duplicates were made, of which 16 were sent to the same number of herbaria, as specified in Tab. (2). 
Tab. 2. The materials belonging to R. Pampanini e R. Pampanini \& R.E.G. Pichi Sermolli (Cyrenaica 1934) sent to the other Herbaria and the presence in virtual herbaria of typus material s. 1. are recorded.

\begin{tabular}{|c|c|c|c|c|c|}
\hline $\begin{array}{c}\text { Herbaria } \\
\text { (Code) }\end{array}$ & Country & Specimens & Sending Date & $\begin{array}{c}\text { Presence in virtual } \\
\text { Herbaria, coll. 1933, } \\
1934\end{array}$ & $\begin{array}{c}\text { Typus } \\
\text { material } \\
\text { s. lato }\end{array}$ \\
\hline $\mathrm{A}$ & USA & 46 & $03 / 01 / 1962$ & & \\
\hline BG & Norway & 9 & $12 / 10 / 1961$ & & \\
\hline $\mathrm{BM}$ & England & 113 & $12 / 09 / 1961$ & & \\
\hline BR & Belgium & 156 & $13 / 09 / 1961$ & 1933(1), 1934(1) & 1 \\
\hline $\mathrm{G}$ & Switzerland & 462 & $\begin{array}{l}\text { 20/06/1953, 26/04/1960- } \\
28 / 04 / 1961\end{array}$ & $1933(6), 1934(6)$ & 7 \\
\hline GE & Italy & 61 & $02 / 01 / 1962$ & & \\
\hline HUJ & Israel & 69 & $12 / 10 / 1961$ & & \\
\hline $\mathrm{K}$ & England & 621 & $02 / 05 / 1960-28 / 04 / 1961$ & 1933(5), 1934(10) & 5 \\
\hline $\mathrm{L}$ & Nederland & 165 & $12 / 09 / 1961$ & unavailable & \\
\hline LISC & Portugal & $17(23)$ & $01 / 1968$ & & \\
\hline MA & Spain & 23 & $01 / 1968$ & & \\
\hline MO & USA & 37 & $03 / 01 / 1961$ & & \\
\hline MPU* & France & 2 & $\begin{array}{l}\text { Sent directly to Maire by } \\
\text { Pampanini before } 1938\end{array}$ & $1933(2)$ & 2 \\
\hline NY & USA & 13 & $28 / 09 / 1961$ & & \\
\hline $\mathrm{S}^{* *}$ & Sweden & 93 & $14 / 09 / 1961$ & 1933(5), 1933(2) & \\
\hline $\mathrm{W}$ & Austria & 301 & $12 / 09 / 1961$ & $1933(1), 1934(4)$ & 3 \\
\hline $\mathrm{ULT} * * *$ & Libya & 28 & After 1968 & & \\
\hline
\end{tabular}

*not sent as exchange; ** in S also 1 specimen collected by Vaccari in 1912; *** sent to ULT directly to L. Boulos, moreover in ULT there are duplicates by Ricceri \& Steinberg 02/1978 (Fezzan)

\section{Alphabetical Index of the Taxa in this work}

New taxa, nomina nuda and families in roman type, heterotypic synonyms and accepted names in italics, the latter indicated with an *. There may be more than one accepted name for each new taxon. Also the infraspecific ranks are in alphabetical order. Including also names in the Addenda and Corrigenda.

Adonis dentata Delile .99

Adonis microcarpa DC.*

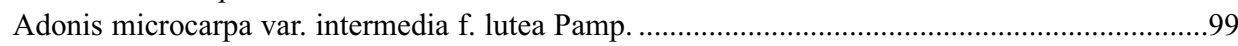

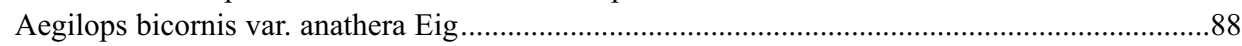

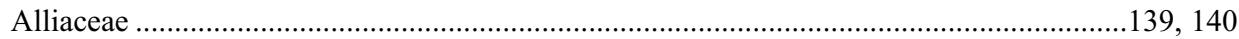

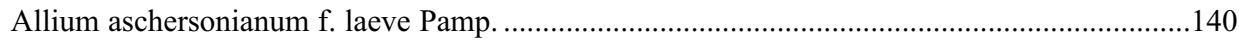

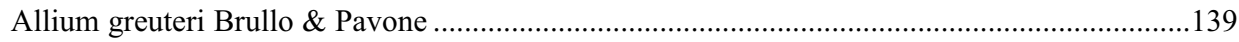

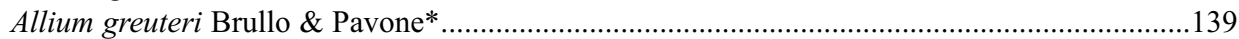

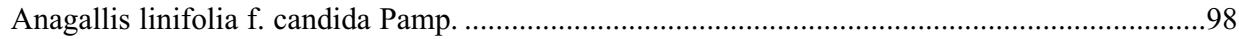

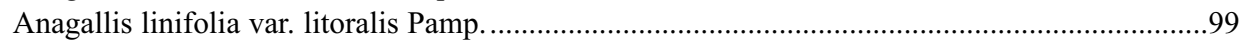

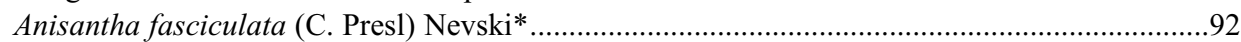

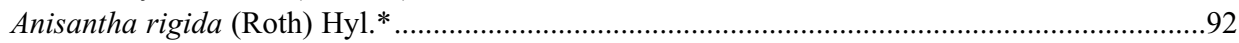

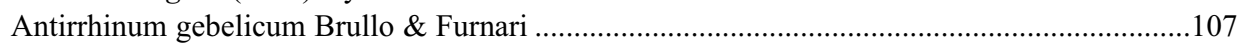

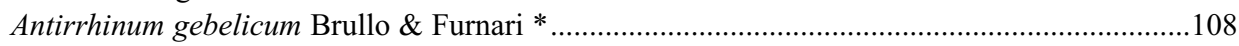

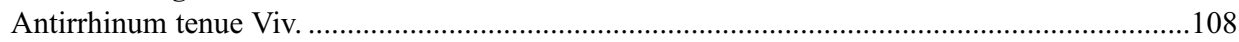

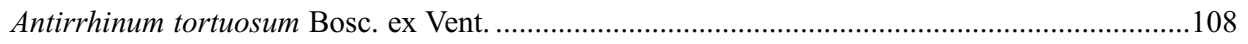


Apiaceae.......

Aristida foexiana Maire \& Wellier .........................................................................................89

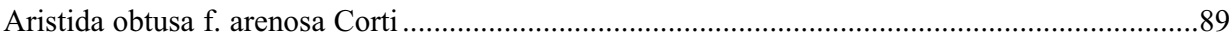

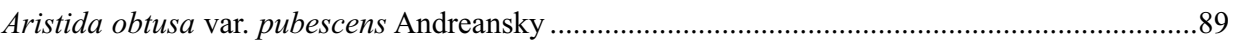

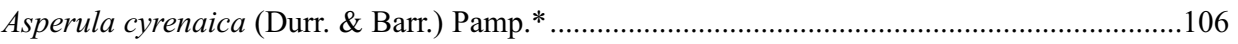

Asperula cyrenaica f. genuina Pamp. .................................................................................... 114

Asperula cyrenaica f. hispidula Pamp. .............................................................................. 106

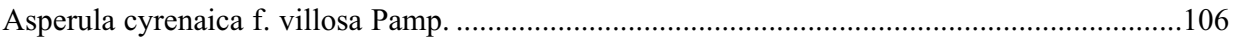

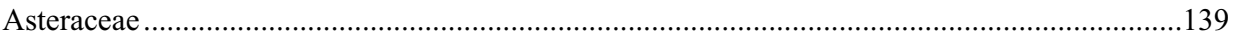

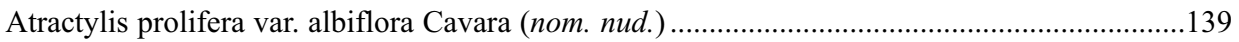

Avena beguinotiana Pamp. .................................................................................................89

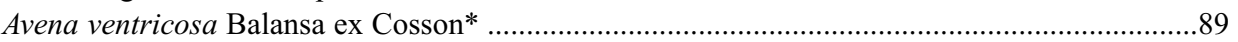

Brachypodium distachyon (L.) P. Beauv.* ..........................................................................90, 91

Brachypodium distachyon var. genuinum f. mite Pamp. .....................................................89

Brachypodium distachyon var. genuinum f. typicum sf. puberulum Pamp.............................90

Brachypodium distachyon var. hispidum Pamp. ...........................................................90

Brachypodium distachyon var. hispidum f. confusum Pamp.................................................90

Brachypodium distachyon var. hispidum Pamp. *...........................................................90

Brachypodium distachyon var. hispidum f. intermedium Pamp. ...........................................90

Brachypodium distachyon var. hispidum f. pseudosubtile Pamp..............................................91

Brachypodium distachyon var. velutinum Pamp..................................................................91

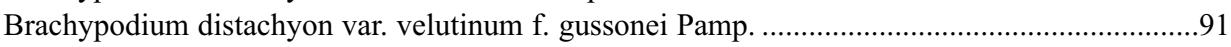

Bromus alopecuros subsp. biaristulatus (Maire) Acedo \& Llamas* .........................................99

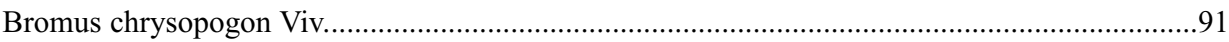

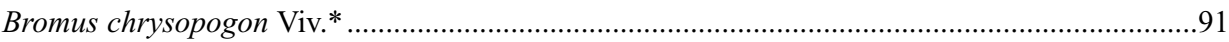

Bromus fasciculatus f. parlatorei Pamp.......................................................................92

Bromus hordeaceus subsp. molliformis (Billot) Maire \& Weiller* ...........................................92

Bromus hordaceus var. molliformis f. villosus Pamp. .........................................................92

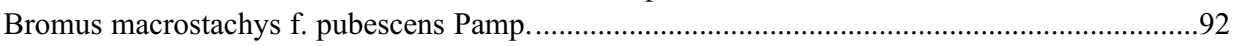

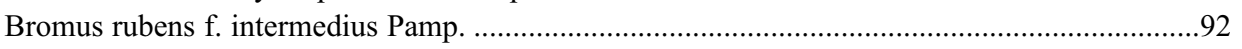

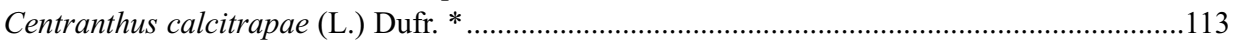

Centranthus calcitrapae f. albiflorus Pamp...............................................................113

Cistanche lutea f. genuina Pamp................................................................................. 114

Cistanche lutea f. pallida Pamp. ...................................................................................... 82

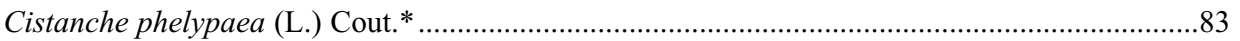

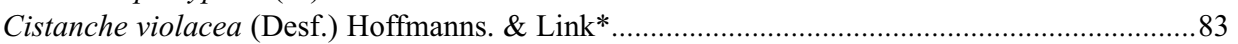

Cistanche violacea f. bicolor Pamp. .................................................................................. 83

Cistanche violacea f. genuina Pamp. ............................................................................. 114

Clematis flammula var. sancti-marini f. angustissima Pamp. ...................................................99

Clematis flammula var. stenophylla Heldr. ex Huntze * ..................................................100

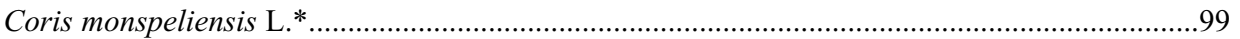

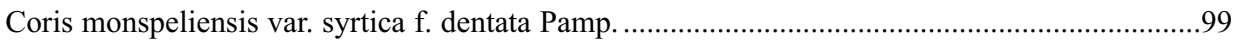

Ctenopsis pectinella var. pubescens Pamp. ...........................................................................93

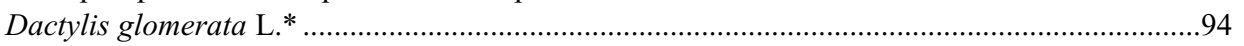

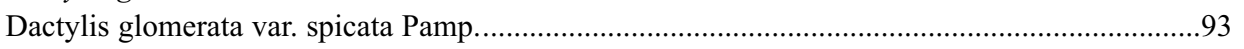

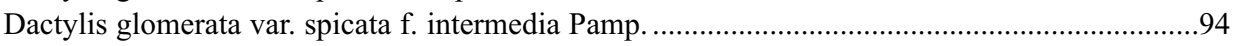

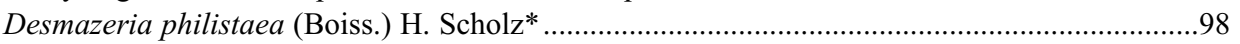

Diplachne festuciformis H. Scholz ..........................................................................94 


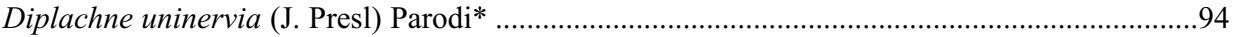

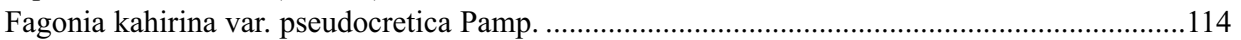

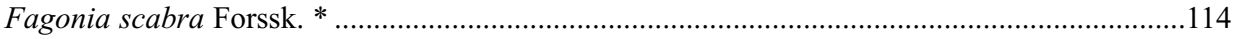

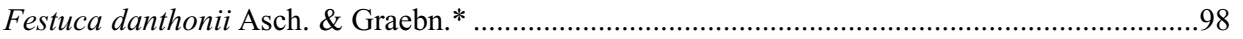

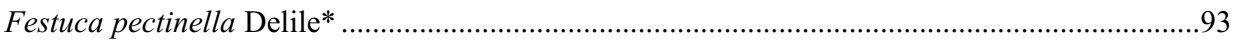

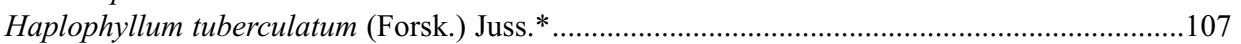

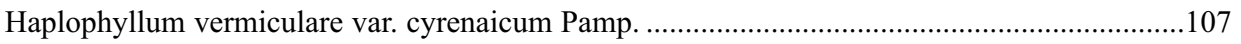

Haplophyllum vermiculare var. cyrenaicum f. latifolium Pamp..............................................107

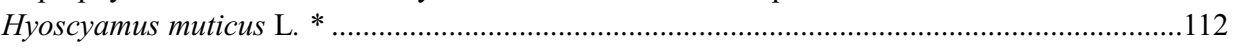

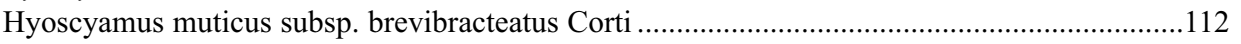

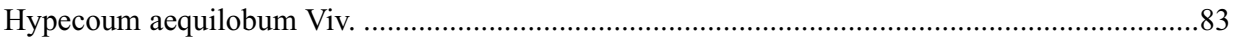

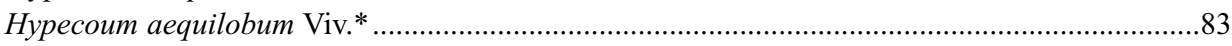

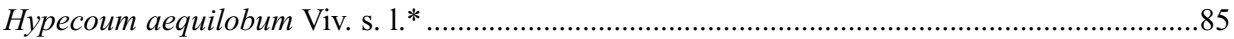

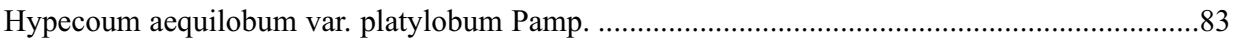

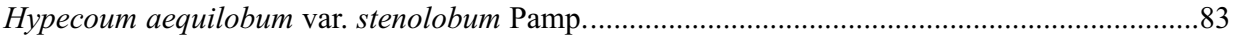

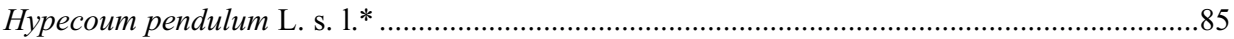

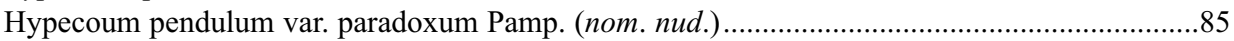

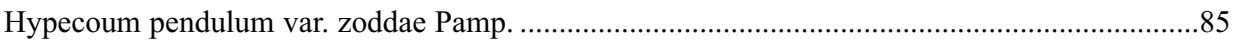

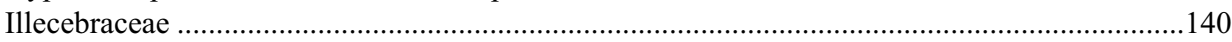

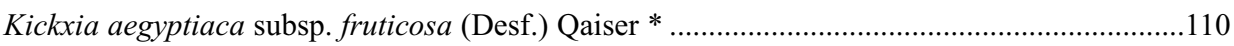

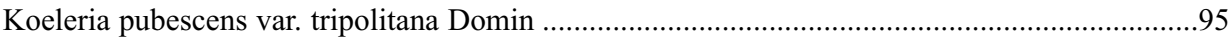

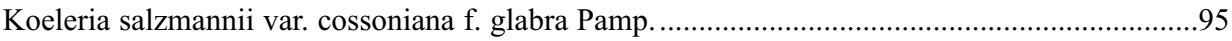

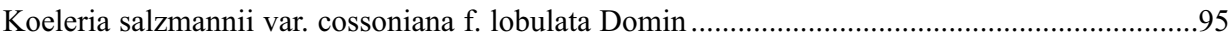

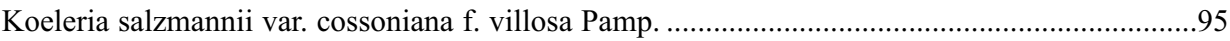

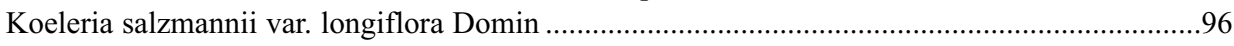

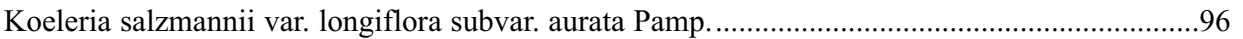

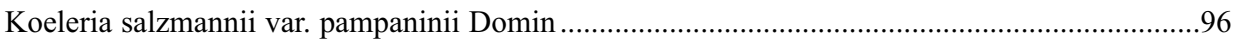

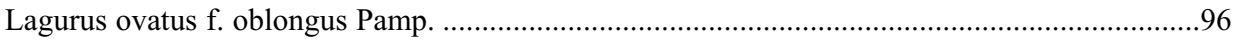

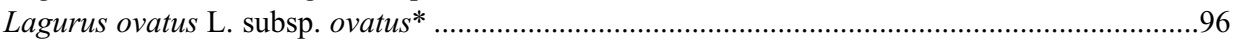

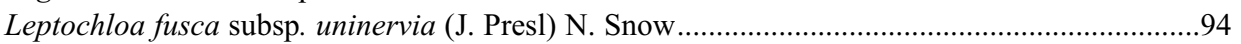

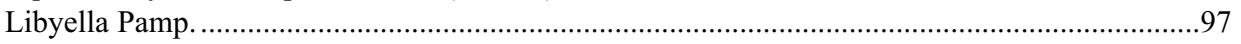

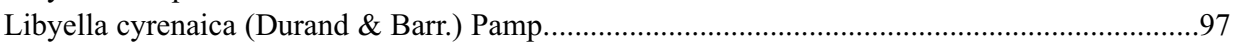

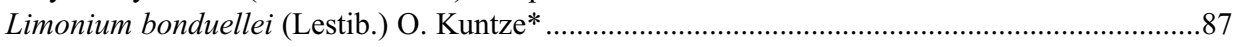

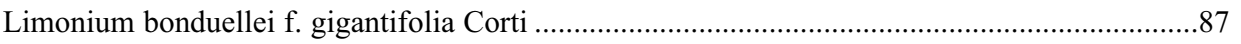

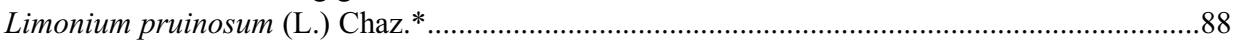

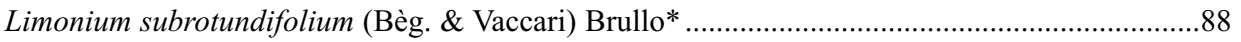

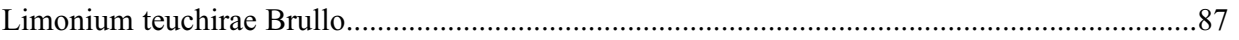

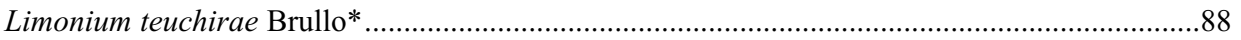

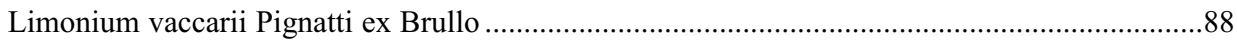

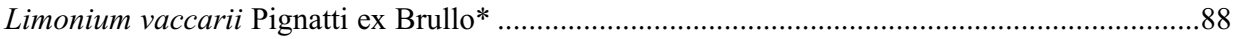

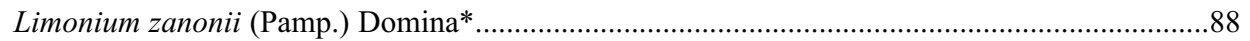

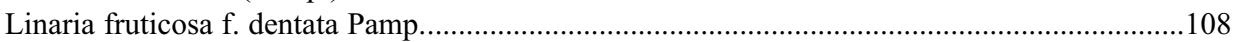

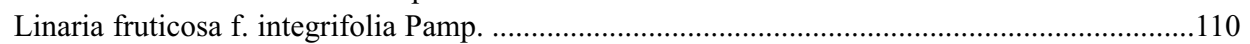

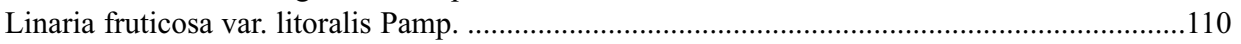

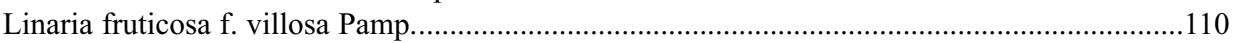

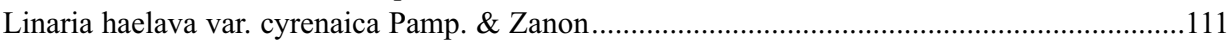

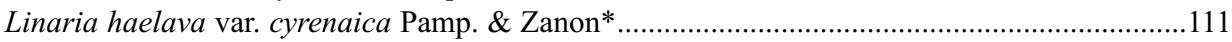

Linaria laxiflora subsp. calcarlongum Qaiser.......................................................................111

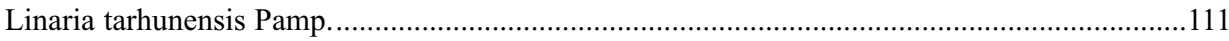


Linaria tarhunensis Pamp. *.....

Linaria tenuis (Viv.) Spreng. * 108,112

Linaria tenuis var. laxiflora Pamp 112

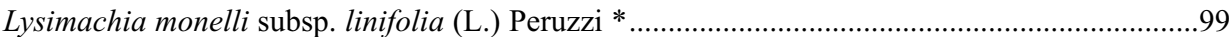

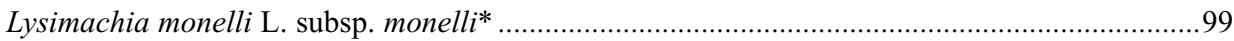

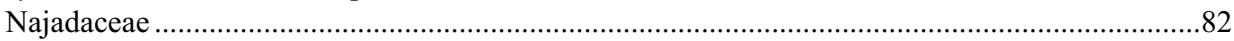

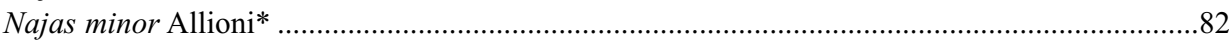

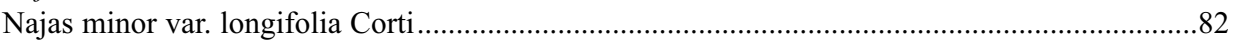

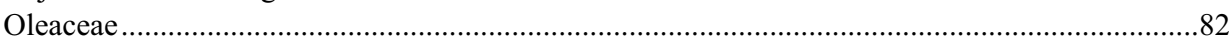

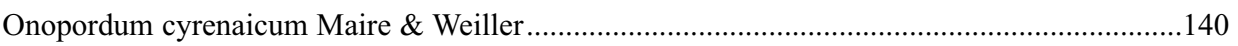

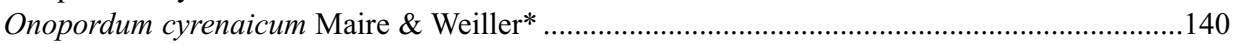

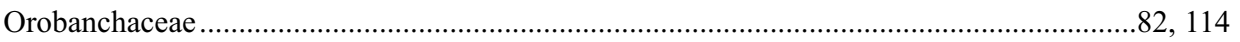

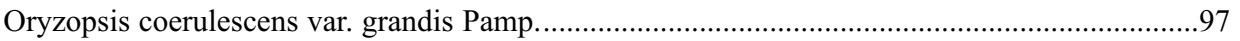

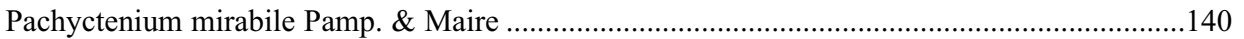

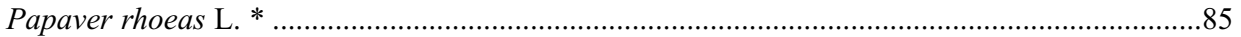

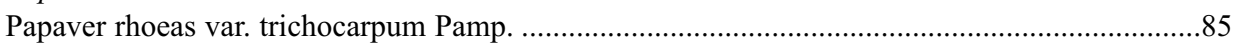

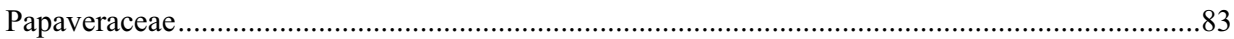

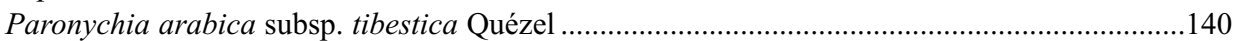

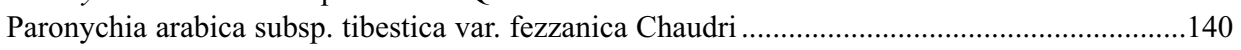

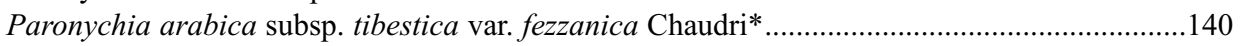

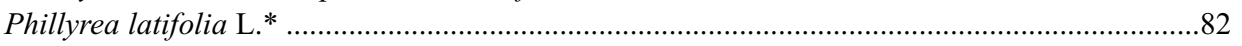

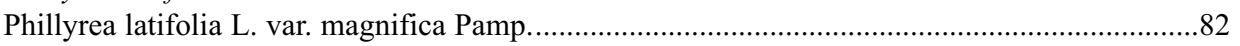

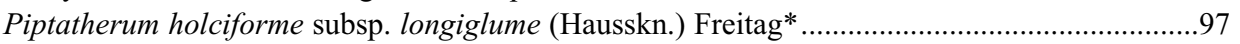

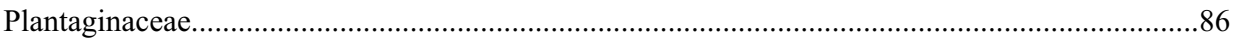

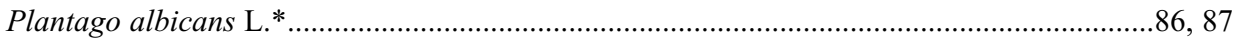

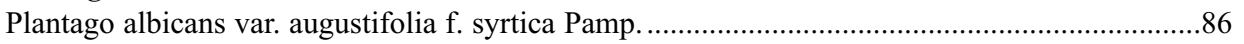

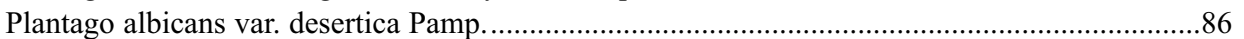

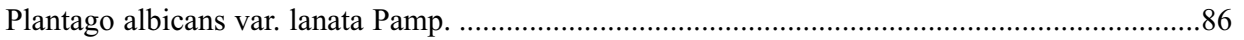

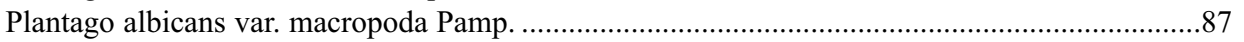

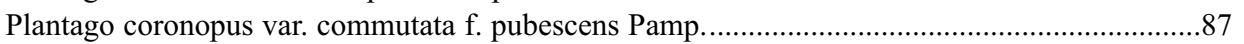

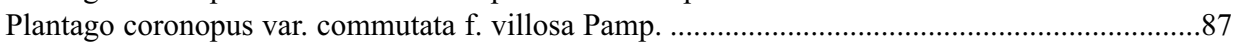

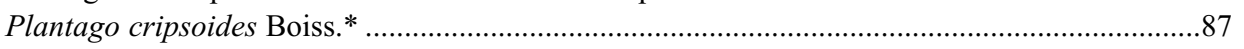

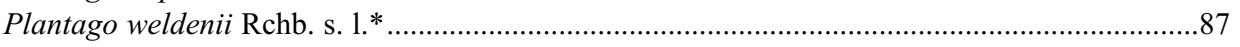

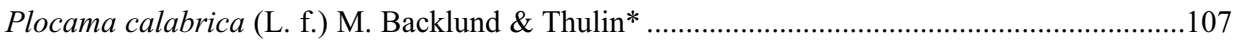

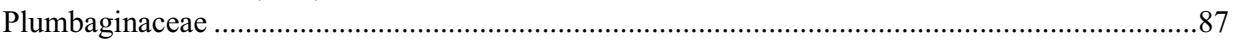

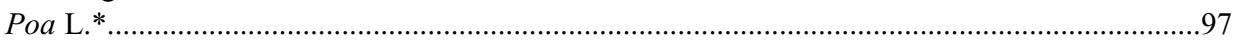

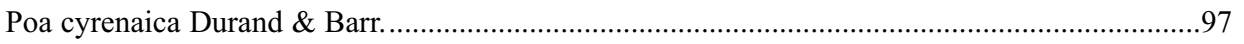

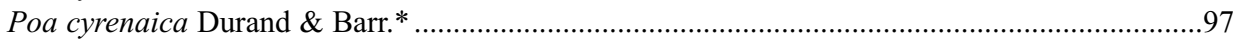

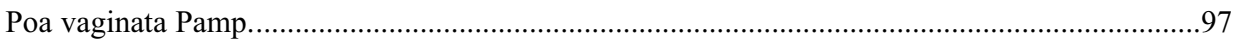

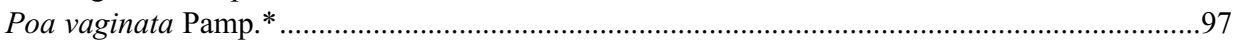

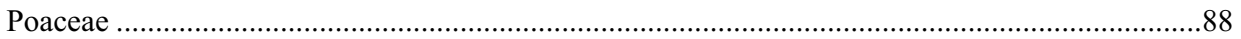

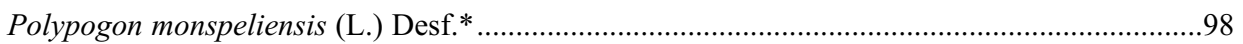

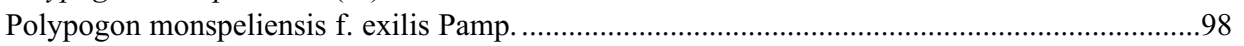

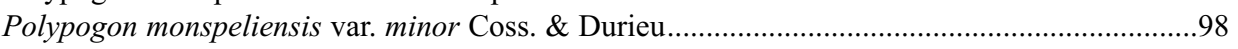

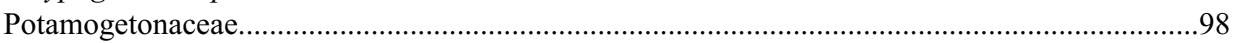

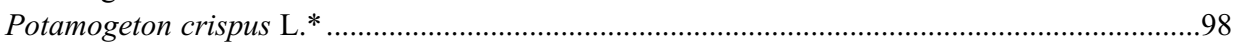

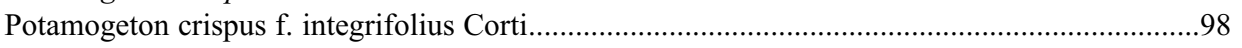

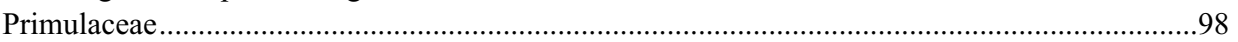

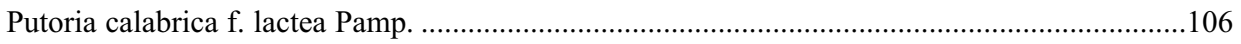




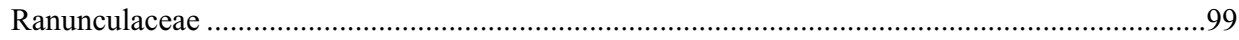

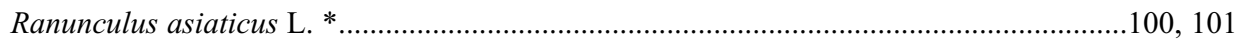

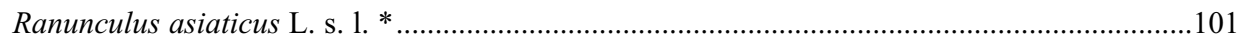

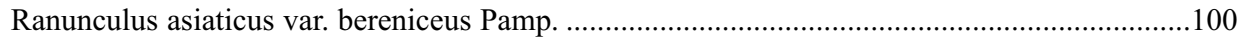

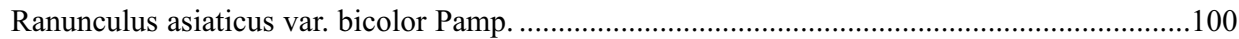

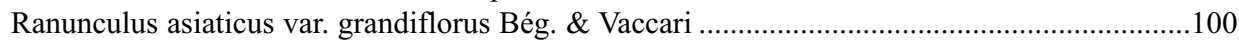

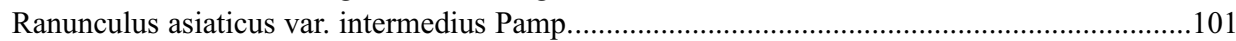

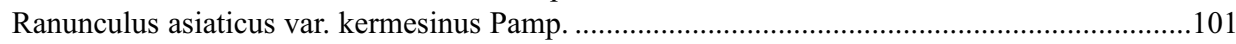

Ranunculus asiaticus var. sanguineus f. purpureus Bég. \& Vaccari (nom. nud.) ...........................101

Ranunculus asiaticus var. vulgaris f. croceus Bég. \& Vaccari (nom. nud) . ..................................101

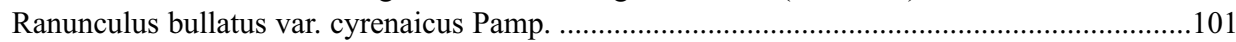

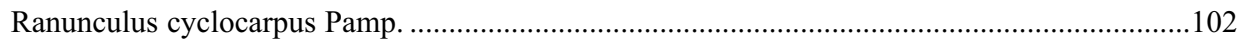

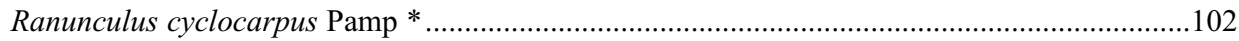

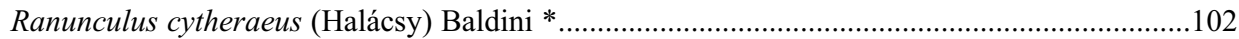

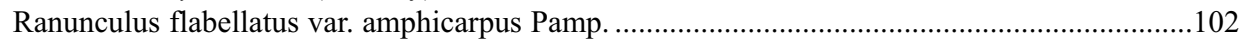

Ranunculus paludosus var. amphicarpus (Pamp.) Boulos * ........................................................102

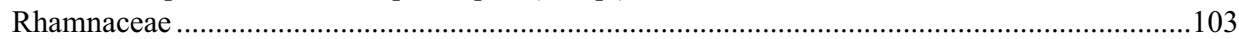

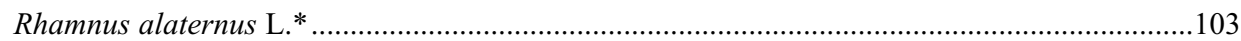

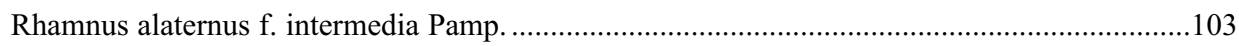

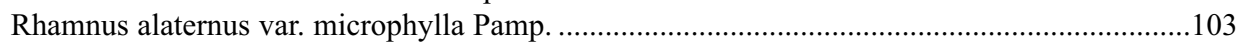

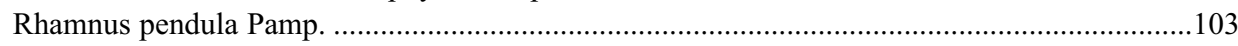

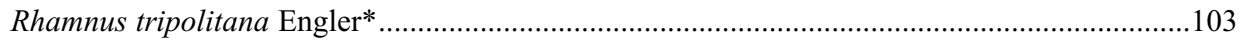

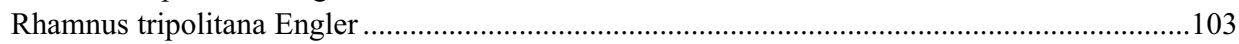

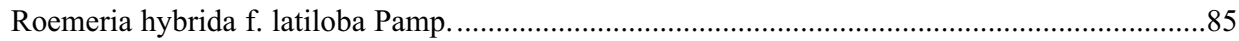

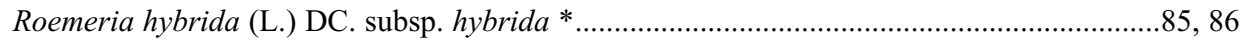

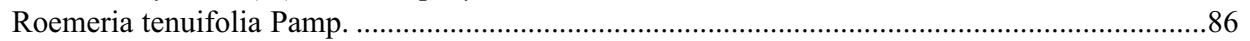

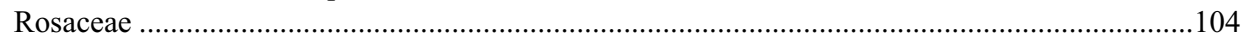

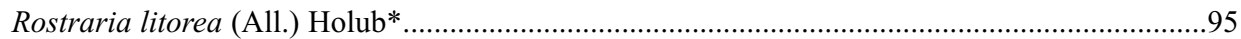

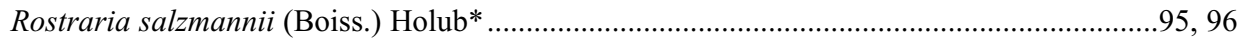

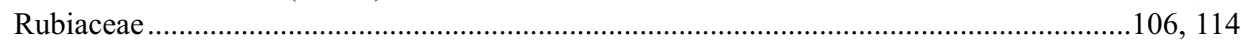

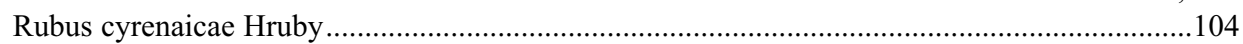

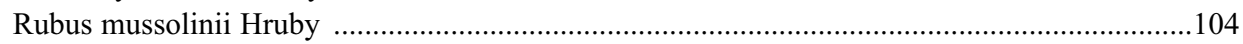

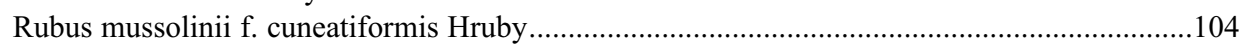

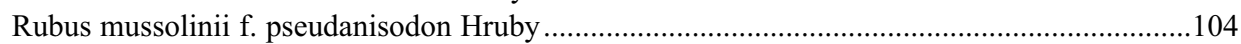

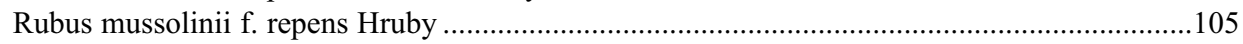

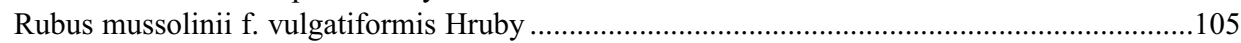

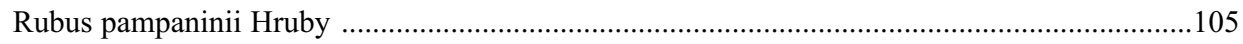

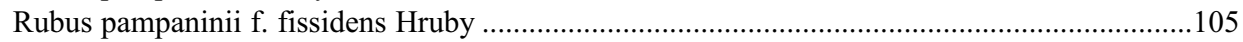

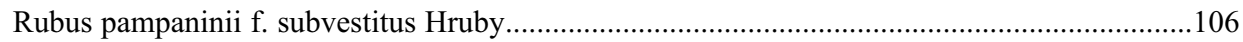

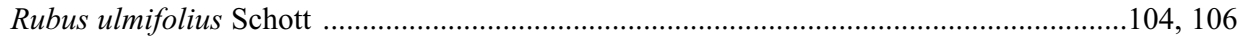

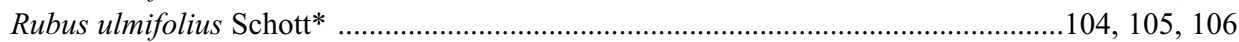

Rubus ulmifolius Schott cfr.* (per R. pampaninii f. subvestitus Hruby).....................................106

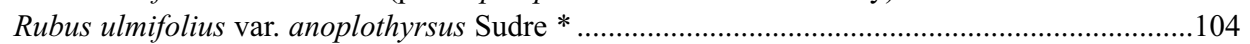

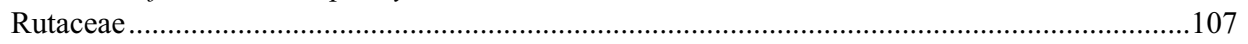

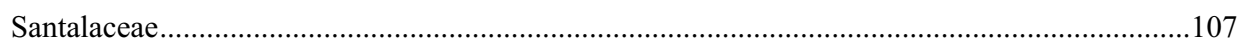

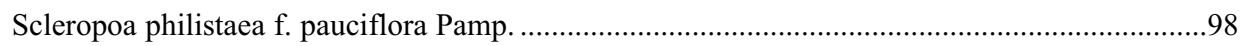

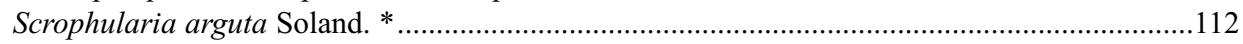

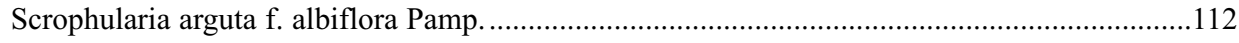

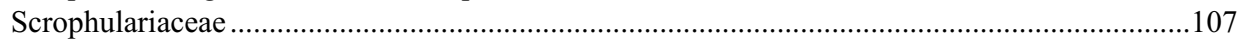


Solanaceae. 112

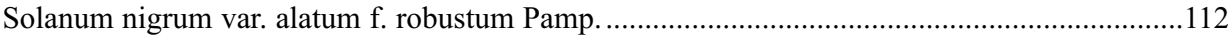

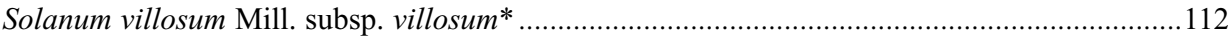

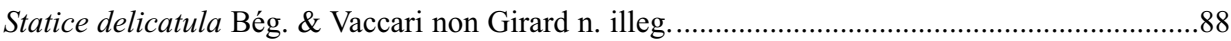

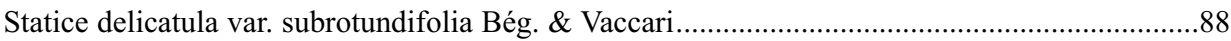

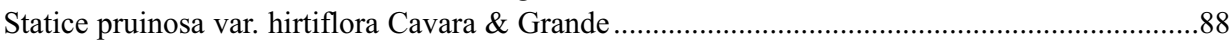

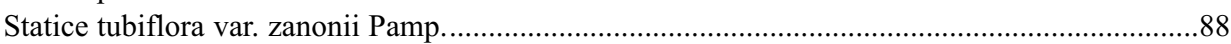

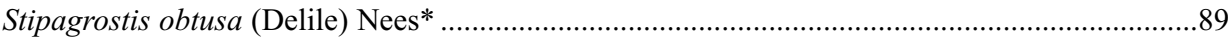

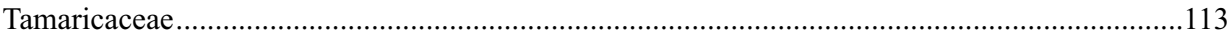

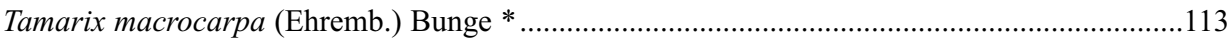

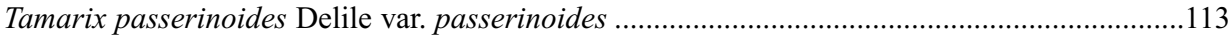

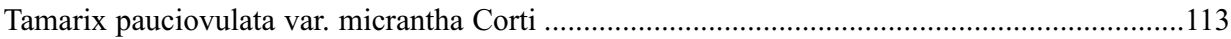

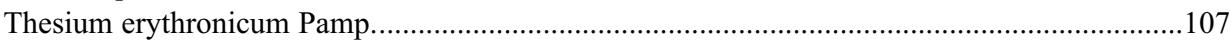

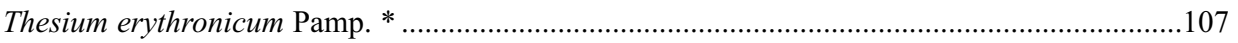

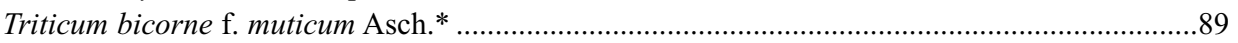

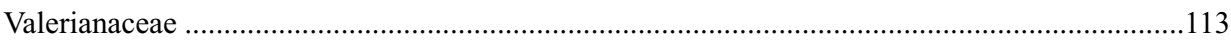

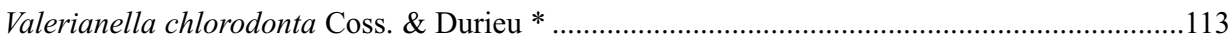

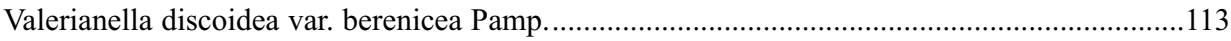

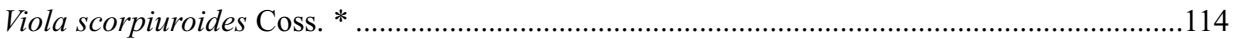

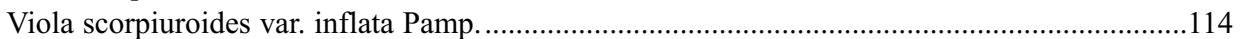

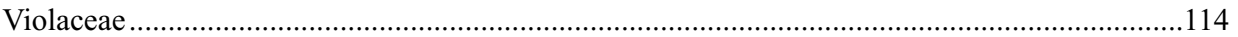

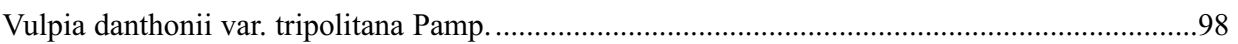

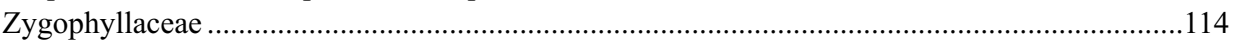

\section{Index of localities and relative collections}

The localities are those published or given on the specimen labels.

Sometimes the same locality is written with a different spelling, e.g.: Gfonta or Sfonta, Maaten or Maten, Sceilabi or Sciallabi, U. Messaf-saf or Saf Saf, Kasr or Gasr. Both versions are given in the list; the taxa followed by '*' (an asterisk), even if mentioned in their protologues or in publications connected with them, are not present at FI. This index also includes localities in the Addenda and Corrigenda.

Abiar Milgha (Ranunculus asiaticus var. bicolor, Roemeria hybrida f. latiloba)

Abiar Milgha a Migi (Centranthus calcitrapae f. albiflorus, Koeleria salzmannii var. longiflora,

Linaria tarhunensis, Ranunculus asiaticus var. bicolor, Scrophularia arguta f. albiflora)

Abiar Milgha sul Ras Neb (Centranthus calcitrapae f. albiflorus)

Abiar Milgha sul Ras Ter (Centranthus calcitrapae f. albiflorus, Koeleria salzmannii var. longiflora,

Ranunculus asiaticus var. bicolor)

Acroma (Bir Acheim), 1.d. Sedra (Bromus fasciculatus f. parlatorei)

Agedabia, 1.d Bag Lia (Koeleria salzmannii var. cossoniana f. glabra*)

Agedabia see el Gtafia

Agedabia (steppa a sud di) (Atractylis prolifera var. albiflora)

Agedabia e Antelat (tra) a Bag Lia (see also Agedabia 1.d. Bag Lia, Haseiat) (Avena beguinotiana,

Hypecoum aequilobum, Hypecoum aequilobum var.stenolobum)

Agedabia e el Agheila (fra) 1.d. Melch en Nogra: (Hypecoum aequilobum var. platylobum, Koeleria

salzmannii var. cossoniana f. glabra, Koeleria salzmannii var. cossoniana f. villosa)

Agedabia see Sahabi (Saniet el Hamar) 
Agedabia e Saumnu (or Sonnu) (tra), 1.d. el Gioch: (Hypecoum aequilobum var. platylobum, Koeleria salzmanni var. cossoniana f. glabra*)

Agheila (el - Steppa di) (Avena béguinotiana, Cistanche violacea f. bicolor)

Agheila (Plantago coronopus var. commutata f. villosa)

Agheila e Maaten Giofer (fra) (Plantago albicans var. augustifolia f. syrtica)

Ain Legmeila (Uadi Messaf-saf) (Bromus macrostachys f. pubescens, Ranunculus cyclocarpus, Rubus mussolinii*, Rubus mussolinii f. cuneatiformis)

Ain Mara (Oryzopsis coerulescens var. grandis)

Ain Scersciara (Linaria fruticosa f. dentata, Ranunculus asiaticus var. bicolor)

Ain Zara (Tripoli) (Koeleria pubescens var. tripolitana, Koeleria salzmannii var. pampanini)

Alessandria (Egitto, nei coltivi dell'antica marea verso) (Roemeria tenuifolia)

Amseat (Avena béguinotiana)

Apollonia, 1. d. Rgua (Dactylis glomerata var. spicata, Ranunculus cyclocarpus)

Apollonia, Uadi Scechaba see Uadi Scechaba

Antica marea presso Alessandria (Egitto): (Roemeria tenuifolia)

Argub Dasc, fra Gubba e l'Uadi Latrun (Dactylis glomerata var. spicata, Dactylis glomerata var. spicata f. intermedia)

Argub Gazal, fra Gubba e l'Uadi Latrun (Asperula cyrenaica f. hispidula, Dactylis glomerata var. spicata $\mathrm{f}$. intermedia)

Auenát (cima di - verso l'Uadi Abd el Málech) (Hyoscyamus muticus subsp. brevibracteatus)

Aziza al Fonduc Scebani (Linaria fruticosa f. villosa)

Barce: 1. d. Bu Gseir (Bromus macrostachys f. pubescens)

Barce: 1.d. Sidi Ahmed Cheila (Bromus macrostachys f. pubescens)

Barce e Tocra (fra), Bu Go(s)eir: (Dactylis glomerata var. spicata)

Beda: 1.d. Sfeiat (Dactylis glomerata var. spicata var. intermedia, Thesium erythronicum)

Beda: Uadi El Kuf 1.d. Bu Breica (Bromus macrostachys f. pubescens, Ranunculus cyclocarpus)

Beda: Uadi Madfa (Dactylis glomerata var. spicata)

Beda see Uadi Msuria

Bengazi (Linaria haelava var. cyrenaica, Poa cyrenaica)

Bengasi e Agedabia, Sidi Ahmed el Magrun see Sidi Ahmed el Magrun

Bengasi e Sollu(c)h (fra) see Giardina

Bir Acheim e Mechili (Trigh Enver Bei: Bir Bu Usceica) (Cistanche lutea f. pallida)

Bir Acheim e Mechili (fra), 1.d. Bir Zeidan (Bromus fasciculatus f. parlatorei)

Bir Bu Usceica see Bir Acheim e Mechili (Trigh Enver Bei: Bir Bu Usceica)

Bir el Ghelania e Brach see Uadi Issa

Bir Zeidan (fra Bir Acheim e Mechili) (Bromus fasciculatus f. parlatorei)

Bomba, 1.d. El Gefar (Dactylis glomerata var. spicata f. intermedia)

Bu Breica see Beda, Uadi El Kuf

$\mathrm{Bu}$ Gheilan (Garian) (Brachypodium distachyon var. genuinum f. mite, Brachypodium distachyon var. hispidum, Brachypodium distachyon var. velutinum, Koeleria salzmannii var. cossoniana $\mathrm{f}$. lobulata)

$\mathrm{Bu} \mathrm{G}(\mathrm{o})$ seir see Barce

Carcúr Brahim (ultimo affluente di sinistra di) (Hyoscyamus muticus subsp. brevibracteatus)

Casa Auari (Ranunculus bullatus var. cyrenaicus)

Chersa (Dactylis glomerata var. spicata)

Cimitero nuovo (Dactylis glomerata var. spicata f. intermedia, Haplophyllum vermiculare var. cyrenaicum)

Cirenaica (H[abitat] in) (Hypecoum aequilobum - drawing)

Cirene (Uadi Bogadir or Belgadir) (Rhamnus pendula)

Cirene: 1.d. Melchifaf see Melchifaf 
Cussabat (Colline a nord-ovest di) (Brachypodium distachyon var. hispidum)

Cussabat, margini dei campi (Adonis microcarpa var. intermedia f. lutea

Cussabat, nelle messi (Adonis microcarpa var. intermedia f. lutea)

Cussabat sul Ras Gelà (Adonis microcarpa var. intermedia f. lutea), Brachypodium distachyon var. genuinum f. mite, Brachypodium distachyon var. hispidum)

Derna (Brachypodium distachyon var. velutinum f. gussonei, Dactylis glomerata var. spicata)

Derna (prope il faro): (Statice delicatula var. subrotundifolia)

Derna (sulle colline) (Ranunculus asiaticus var. sanguineus f. purpureus)* n. nudum

Derna, Uadi Derna (Asperula cyrenaica f. genuina, Dactylis glomerata var. spicata f. intermedia, Rubus cyrenaicae)

Derna: Uadi Naga see Uadi Naga

Derna e Mechili (fra), 1.d. Siret Medanaat see Siret Madanaat

Derna e Mechili (fra), Uadi Hiscia/el Hescia (Plantago coronopus var. commutata f. villosa)

Derna (vivaio): (Dactylis glomerata var. spicata f. intermedia)

Due Palme (Ranunculus asiaticus var. bereniceus*, Ranunculus bullatus var. cyrenaicus)

Due Palme e Benina (fra): (Dactylis glomerata var. spicata f. intermedia)

Due Palme e la linea ferroviaria di Benina, in direzione del Giok Kebir (fra le) (Ranunculus bullatus var. cyrenaicus)

Elbárcat (Reg. di Gat-Fezzan occidentale) (Najas minor var. longifolia)

Elbárcat e 1'U. Iséien (valico tra), verso Elbárcat. Fezzan occidentale: (Limonium bonduellei f. gigantifolia)*

El Garib e Tolmeta (fra, Uadi el Fahaga) (Rhamnus alaternus var. microphylla)

El Ghegab: (Dactylis glomerata var. spicata)

El Grein: (Avena béguinotiana, Hypecoum aequilobum var. stenolobum)

El Gubba (Dactylis glomerata var. spicata)

Féuet (Reg. di Gat, presso; nella piana sabbiosa e sassosa) (Tamarix pauciovulata var. micrantha)

Fonduc Scebani see Aziza

Fuehat :(Ranunculus asiaticus var. bereniceus* ${ }^{*}$ Roemeria tenuifolia)

Ganfuda (Dactylis glomerata var. spicata)

Ganfuda e Suani Tica (Dactylis glomerata var. spicata)

Gargadesc (Linaria fruticosa var. litoralis)

Gargáf (sul), a nord di Brach. Fezzan settentrionale: (Limonium bonduellei f. gigantifolia)

Garian (in cultis) (Hypecoum pendulum var. zoddae)

Gariunes (Hypecoum aequilobum var. platylobum)

Gasr Beni Gdam e Sidi Abd el Uahed (fra-Uadi el Kuf): (Asperula cyrenaica f. villosa, Brachypodium distachyon f. confusum, Ranunculus cyclocarpus)

Gasr Zaarura see Messa

Ghegab (Dactylis glomerata var. spicata, Dactylis glomerata var. spicata f. intermedia)

Giardina (Dactylis glomerata var. spicata, Valerianella discoidea var. berenicea)

Giok [Kebir] (Statice tubiflora var. zanonii)

Giuliana (Forte di) (Haplophyllum vermiculare var. cyrenaicum)

Giuliana (Punta) (Hypecoum aequilobum var. platylobum)

Gtafia (Fagonia kahirina var. pseudocretica)

Guarscià e Gariunes (fra): (Dactylis glomerata var. spicata)

Gubba e l'Uadi el Atrum, (fra) 1.d. Argub Gazal see Argub Gazal

Gubba e l'Uadi Latrun (fra), 1.d. Argub Dasc see Argub Dasc

Halg Bu-Rues see Ridotta Piemonte (Derna)

Hania e Messa (fra) see Mregheb

Hauari (Regione di Bengasi) (Hypecoum aequilobum var. platylobum) 
Henni see Oasi di Tripoli

Heseiat see Agedabia e Antelat

Istmo di Suez (nel deserto dell'Egitto): (Roemeria tenuifolia)

Juliana (near Benghasi): (Aegilops bicornis var. anathera)

Kam el Gaar (pianura di) (Koeleria salzmannii var. longiflora)

Karmu (Dactylis glomerata var. spicata)

Kasr Daun (Brachypodium distachyon var. velutinum, Ctenopsis pectinella var. pubescens)

Kars Doga see Uadi Msaaba

Kasr Garian, nei campi incolti (Anagallis linifolia f. candida, Linaria fruticosa f. integrifolia)

Kasr Garian (margini dei campi) (Vulpia danthonii var. tripolitana)

Kasr Tarhuna (Ranunculus asiaticus var. bicolor)

Kasr Tarhuna (colline a est di) (Bromus rubens f. intermedius, Ctenopsis pectinella var. pubescens, Koeleria salzmannii var. longiflora subvar. aurata)

Kseibia (Dactylis glomerata var. spicata)

Kuebia (Dactylis glomerata var. spicata)

Labrach (el Abrach ?), Mghernes (Bromus macrostachys f. pubescens, Dactylis glomerata var. spicata f. intermedia)

Lamluda (Bromus macrostachys f. pubescens*, Ranunculus cyclocarpus)

Lete (Dactylis glomerata var. spicata)

$\mathrm{Ma}(\mathrm{a}) \tan$ Borgù: (Dactylis glomerata var. spicata f. intermedia)

Maaten Giofer see Uadi Faregh

Magnae Syrteos (grande Sirte): (Antirrhinum tenue - drawing)

Maraua (Dactylis glomerata var. spicata f. intermedia)

Marsa Brega (Koeleria Salzmanni var. cossoniana f. glabra*)

Marsa Brega see el Grein

Martuba, Uadi Bgar (Brachypodium distachyon var. genuinum f. typicum sf. puberulum, Dactylis glomerata var. spicata, Dactylis glomerata var. spicata f. intermedia)

Mechili: Uadi Ramla (Cistanche lutea f. pallida, Plantago coronopus var. commutata f. pubescens)

Melch en Nogra see Agedabia e el Agheila (fra)

Melchifaf (Brachypodium distachyon var. velutinum f. gussonei, Ranunculus asiaticus var. intermedius, Ranunculus asiaticus var. kermesinus)

Melch en Nogra seeAgedabia e el Agheila (tra) 1.d. Melch en Nogra

Merg (piana Ovest): (Dactylis glomerata var. spicata f. intermedia)

Merg see Sidi Gibrin

Messa, Uadi Tmista, 1. d. Umm Rcham (Dactylis glomerata var. spicata, Putoria calabrica f. lactea)

Messa, Gasr Zaarura (Dactylis glomerata var. spicata f. intermedia)

Mghernes see Labrach

Migi see Abiar Milgha

Misrata e Ras Zug (Fra, nei campi arenosi e lungo la sebhka) (Ranunculus asiaticus var. grandiflorus*)

Mregheb (Phyllyrea latifolia var. magnifica)

Msid di Mesellata (Centranthus calcitrapae f. albiflorus)

Msus (Cistanche violacea f. bicolor, Plantago coronopus var. commutata f. pubescens)

Nalut (dintorni di) (Coris monspeliensis var. syrtica f. dentata*)

Naughia (Dactylis glomerata var. spicata)

Oasi di Giarabub (Polypogon monspeliensis f. exilis)

Oasi di Tripoli ad Henni (Linaria tenuis var. laxiflora)

Oasi di Zanzur (Linaria fruticosa var. litoralis)

Palmeto (Monastir) (Hypecoum aequilobum var. platylobum)

Porto Bardia (sui costoni aridi) (Statice pruinosa var. hirtiflora) 
Qasr Safran (Rhamnus tripolitana)

$\mathrm{Ra}(\mathrm{h})$ aba (Dactylis glomerata var. spicata, Dactylis glomerata var. spicata f. intermedia, Haplophyllum vermiculare var. cyrenaicum, Haplophyllum vermiculare var. cyrenaicum $\mathrm{f}$. latifolium)

Ramle di Abukir (nel deserto di-Egitto): (Roemeria tenuifolia)

Ras Argobinani see Uadi Ksea

Ras Bu Ganus (Centranthus calcitrapae f. albiflorus, Roemeria hybrida f. latiloba)

Ras Bu Tauil (Adonis microcarpa var. intermedia f. lutea, Roemeria hybrida f. latiloba)

Ras Ghenai (Adonis microcarpa var. intermedia f. lutea, Centranthus calcitrapae f. albiflorus, Koeleria salzmannii var. longiflora subvar. aurata, Roemeria hybrida f. latiloba)

Ras Omcteba see Uadi Garian

Ras Tecut (Brachypodium distachyon var. velutinum, Centranthus calcitrapae f. albiflorus)

Regima (Dactylis glomerata var. spicata)

Rgua see Apollonia

Ridotta Piemonte (verso l'Halg Bu-Rues) (Viola scorpiuroides var. inflata)

Ridotta Tilgher (a $10 \mathrm{Km}$ da Agedabia) (Koeleria salzmannii var. cossoniana f. villosa)

Ridotta Zorda (Merg) (Dactylis glomerata var. spicata f. intermedia)

Saf-Saf (es-Cirene) (Ranunculus asiaticus var. intermedius, Ranunculus cyclocarpus, Ranunculus flabellatus var. amphicarpus *)

Saf -Saf, Uadi Bu Meddas (Brachypodium distachyon var. genuinum f. typicum sf. puberulum)

Sahabi (Saniet el Hamar) (Avena béguinotiana)

Sceleidima (esc-) (Cistanche violacea f. bicolor)

Sciallabi (Sceilabi) el Bebas (Haplophyllum vermiculare var. cyrenaicum, Linaria haelava var. cyrenaica*)

Sedra see Acroma

Sebchet el Cuz (Limonium teuchirae)

Selmani e Suani Osman (fra) (Dactylis glomerata var. spicata, Hypecoum aequilobum var. platylobum)

Sfax (TUNISIA); (Antirrhinum tenue)

Sfeiat see Beda

Sf(1)onta (also Ghfonta?) (Messa): (Dactylis glomerata var. spicata)

Sidi Ahmed Che(i)la see Barce

Sidi Ahmed el Magrun (fra Bengasi e Agedabia): (Dactylis glomerata var. spicata, Dactylis glomerata var. spicata f. intermedia, Plantago coronopus var. commutata f. pubescens)

Sidi Bu Amud see Fra Tobruk e Bardia

Sidi Frag e El Magrun (fra) (Plantago coronopus var. commutata f. villosa)

Sidi Gibrin (Merg) (Bromus chrysopogon)

Sidi Kalifa (Dactylis glomerata var. spicata)

Sinai (nel deserto dell'Egitto): (Roemeria tenuifolia)

Siret Bettamer (el Gubba) (Ranunculus cyclocarpus)

Siret Medanaat, fra Derna e Mechili (Dactylis glomerata var. spicata)

Slonta (Brachypodium distachyon var. velutinum f. gussonei, Bromus macrostachys f. pubescens, Dactylis glomerata var. spicata f. intermedia, Ranunculus flabellatus var. amphicarpus)

Slonta (steppa a Poterium) (Dactylis glomerata var. spicata f. intermedia)

Socna (el Jofra - oasi artificiale) (Diplachne festuciformis)

Suani Bazar (Dactylis glomerata var. spicata)

Suani Beni Adem (nella steppa) (Lagurus ovatus f. oblongus*)

Tobruk (Dactylis glomerata var. spicata, Limonium vaccarii)

Tobruk (in collibus aridis) (Ranunculus asiaticus var. vulgaris f. croceus) Nomen nudum

Tobruk e Bardia (fra): 1.d. Sidi Bu Amud (Bromus fasciculatus f. parlatorei)

Tocra e Tolmeta (fra) (Dactylis glomerata var. spicata f. intermedia)

Tripoli e Gargaresc (fra) (Anagallis linifolia var. litoralis) 
Tunin, $2^{\circ}$ deposito d'acqua (Reg. di Gat - Fezzan occidentale) (Potamogeton crispus f. integrifolius) Uadi Abd el Málech see Auenát

Uadi Belgadir(or Bogadir, Beldgadir) (Brachypodium distachyon var. velutinum f. gussonei, Rhamnus pendula, Rubus cyrenaicae, Rubus pampaninii* (= R. cyrenaicae $\mathrm{x}$ sanctus), Rubus pampaninii f. fissidens, Solanum nigrum var. alatum f. robustum)

Uadi Beregtd (Beda) (Ranunculus cyclocarpus)

Uadi Bgar see Martuba

Uadi Buten (Cirene) (Brachypodium distachyon var. genuinum f. typicum sf. puberulum)

Uadi Beregd see Beda

See also Cirene Uadi Bu Meddas

Uadi Bu Meddas see also Saf Saf (as)

Uadi Bu Ms(c)eifa see Tolmeta

Uadi Bu Nabeh (Cirene) (Ranunculus cyclocarpus, Rhamnus pendula, Rubus mussolinii f. vulgatiformis, Rubus pampaninii ( $=R$. cyrenaicae $x$ sanctus) $f$. subvestitus)

Uadi Derna (Dactylis glomerata var. spicata f. intermedia, Onopordum cyrenaicum, Rubus cyrenaicae)

Uadi el Atrum (Thesium erythronicum)

Uadi el Fahaga see Garib e Tolmeta

$\mathrm{U}(\mathrm{W})$ adi el K(C)uf (Antirrhinum gebelicum)

Uadi El Kuf 1.d. Bu Breica see Beda

Uadi Faregh e Maatan Risam (fra 1') (Plantago albicans var. desertica)

Uadi Garian (Brachypodium distachyon var. hispidum, Brachypodium distachyon var. hispidum $\mathrm{f}$. intermedium, Brachypodium distachyon var. velutinum, Koeleria pubescens var. tripolitana, Linaria fruticosa $\mathrm{f}$. integrifolia)

Uadi Garian sul Ras Omcteba (Centranthus calcitrapae f. albiflorus)

Uadi Hofra (Cirene) (Dactylis glomerata var. spicata f. intermedia, Ranunculus cyclocarpus, Rubus cyrenaicae)

Uadi Issa (tra Bir el Ghelania e Brach) (Aristida obtusa f. arenosa)

Uadi Ksea (pianura dell') (Plantago albicans var. lanata)

Uadi Ksea, sul Ras Argobinani (Adonis microcarpa var. intermedia f. lutea, Brachypodium distachyon var. hispidum f. pseudosubtile, Brachypodium distachyon var. velutinum, Centranthus calcitrapae f. albiflorus, Koeleria salzmannii var. pampanini*)

Uadi Madfa see Beda

Uadi Megenin presso Ain Zara (Plantago albicans var. macropoda)

Uadi Messaf-saf (Beda) (Rubus mussolinii*)

Uadi Messaf-saf see also Ain Legmeila (Beda)

Uadi Msaaba (Koeleria salzmannii var. longiflora)

Uadi Msaaba, a Kars Doga (Bromus hordaceus var. molliformis f. villosus, Linaria fruticosa f. integrifolia, Roemeria hybrida f. latiloba, Scleropoa philistea f. pauciflora)

Uadi Msuria (Beda) (Dactylis glomerata var. spicata, Rhamnus pendula, Rubus mussolinii f. pseudanisodon)

Uadi Naga (Derna) (Bromus macrostachys f. pubescens, Dactylis glomerata var. spicata f. intermedia)

Uadi Ramla (Mechili) (Brachypodium distachyon var. genuinum f. typicum sf. puberulum)

Uadi Sahal, Fra Tobruk e Bardia (Dactylis glomerata var. spicata)

Uadi Sart (Brachypodium distachyon var. hispidum f. pseudosubtile, Centranthus calcitrapae f. albiflorus- 2 specimens, Linaria fruticosa f. dentata, Vulpia danthonii var. tripolitana)

Uadi Scechaba (Asperula cyrenaica f. hispidula, Dactylis glomerata var. spicata, Rhamnus pendula)

Uadi Scisu (Beda) (Brachypodium distachyon var. velutinum f. gussonei, Bromus macrostachys f. pubescens, Dactylis glomerata var. spicata; Dactylis glomerata var. spicata f. intermedia)

Uadi esc Suenia see Umm er Rzem 
Uadi Tenziua/Tersiva (nella steppa) (Brachypodium distachyon var. genuinum f. mite, Ctenopsis pectinella var. pubescens)

Uadi Tenziua (nelle messi) (Adonis microcarpa var. intermedia f. lutea, Linaria tarhunensis)

Uadi Tenziua, pianura a S. W. del Ras Maader (Linaria tarhunensis, Papaver rhoeas var. trichocarpum)

Uadi Tenziua, sul Ras Maader (Brachypodium distachyon var. hispidum f. intermedium, Linaria fruticosa f. villosa)

Uadi Tmista (Cirene) (Dactylis glomerata var. spicata, Rhamnus alaternus f. intermedia)

Uadi Uardama (Brachypodium distachyon var. velutinum f. gussonei, Dactylis glomerata var. spicata $\mathrm{f}$. intermedia, Ranunculus cyclocarpus, Rubus mussolinii f. repens)

Uadi Umm el Anain (Regione di Merg) (Clematis flammula var. sancti-marini f. angustissima)

$\mathrm{U}(\mathrm{W})$ adi Zigza (Paronychia arabica subsp. tibestica var. fezzanica)

Umm er Rzem (Barce) (Dactylis glomerata var. spicata)

Umm er Rzem, Uadi Suenia (Dactylis glomerata var. spicata, Poa vaginata, Ranunculus asiaticus var. intermedius)

Wadi el Bab (Allium greuteri)

Zuetina a nord est di Agedabia (Cistanche violacea f. bicolor, Hypecoum aequilobum var. platylobum, Koeleria Salzmanni var. cossoniana f. glabra*)

Zuetina see Ghemines

\section{Acknowledgements}

We wish to thank Prof. E. Nardi, W. Greuter and Dr. L. Cecchi (for suggestions on some typifications), M. Roeser and R. Soreng (for information on the genus Lybiella), L. Pignotti and M.C. Donnini Macciò (for translating from German some parts of certain works, the former also for assistance in bibliographic research), the director of the Florence Tropical Herbarium, Dr. R.M. Baldini, for the use of the library, Isabelle Laffont-Schwob (for the sad news regarding Dr. Josette Viano), A. Managlia, curator of BOLO (for calligraphy evaluation- part 1 of the work), our colleagues of the B, GE, K, LD, MPU, P, RO, ULT herbaria for their collaboration in checking and sending exsiccata/or images, our friends G. Ruocco and S. Miranda, the last also co-author of this work, for helping in Herbarium research, Dr. G. Palfinger of the Wien Natural History Museum for her kind bibliographical consultation. Many thanks are also due to all the staff of the Botanical Section of the Science Library of Florentine University for their patient collaboration when we asked for so many manuscripts and to other Libraries here in Italy and abroad, without whose help much of this work would never have been possible.

\section{Contribution of the Authors:}

P. Cuccuini \& C. Nepi: Coordinators, Museology and the other taxa (Papaveraceae, Plantaginaceae, Primulaceae, Ranunculaceae, Santalaceae, Scrophulariaceae (Cuccuini with M. Abuhadra), Solanaceae, Tamaricaceae, Valerianaceae, Violaceae, Zygophyllaceae)

Mohamed N. Abuhadra: Orobanchaceae (with G. Domina), Scrophulariaceae (with P. Cuccuini)

E. Banfi: Poaceae

G. Domina: Oleaceae, Orobanchaceae (with M. Abuhadra), Plumbaginaceae, Rutaceae

E. Luccioli: graphic

S. Miranda: Najadaceae, Potamogetonaceae

K. Pagitz: Rosaceae

M. Thiv: Rhamnaceae

E. Vela: Rubiaceae 


\section{References}

The reader is referred to the References of Part 1 (Cuccuini \& al. 2015) for any works not mentioned in this second part

Acedo, C. \& Llamas, F. 1994: Bromus alopecuros a new record for the Iberian Peninsula, with morphological, chorological and nomenclatural observations on the B. lanceolatus group. - Fl. Medit. 4: 203-212.

Alavi, S. A. 1977: Valerianaceae. - Pp. 1-16 in: Jafri, S. M. H. \& El Gadi, A. (eds.), Flora of Libya, 46. - Tripoli.

- 1983: Asteraceae. - Pp. 1-455 in: Jafri, S. M. H. \& El Gadi, A. (eds.), Flora of Libya, 107. Tripoli.

Ali, S. I. 1977: Coridaceae. - Pp. 1-3 in: Ali, S. I. \& Jafri, S. M. H. (eds.), Flora of Libya, 6. - Tripoli. Auctores vari 1977-1988: Flora of Libya. 1-144. - Tripoli.

Baldini, R. M. \& Jarvis, C. 2002: Typification of Ranunculus bullatus L. (Ranunculaceae). - Bull. Nat. Hist. Mus. Lond. (Bot.) 32(1): 7-11.

Béguinot, A. \& Vaccari, A. 1913: Secondo contributo alla Flora della Libia con notizie sulle piante utili osservate. - Min. Colon., Monogr. Rapp. Colon. 7: 1-40.

— \& — 1914: Terzo contributo alla Flora della Libia. - Ann. Bot. (Roma) 12(1): 87-149.

Beier, B.-A. 2005: A revision of the desert shrub Fagonia (Zygophyllaceae). - Syst. Biodiv. 3(3): 221-263.

Boulos, L. 1979: A check - list of the Libyan flora. 2. Salicaceae to Neuradaceae. - Candollea 34: 21-48.

Brullo, S. 1978: Il genere "Limonium" Miller in Cirenaica. - Webbia 33(1): 137-158.

— \& Furnari, F. 1979: Taxonomic and nomenclatural notes on the flora of Cyrenaica (Lybia). Webbia 34(1): 155-174. doi: 10.1080/00837792.1979.10670168

— \& - 1996: La vegetazione del Gebel el-Akhdar (Cirenaica settentrionale). - Boll. Acc. Gioenia Sci. Nat. 27(347): 197-412.

— \& Pavone, P. 1983: Allium gruteri sp. nova (Liliaceae) from Cyrenaica and its relationships with the Allium cupanii group. - Willdenowia 13(1): 115-122.

Cavara, F. 1928: Piante nuove o rare della Libia (IV contributo). - Bull. Orto Bot. Napoli 9(1): 41-54. Chaudhri, M. N. 1968: A revision of the Paronychiinae. - Meded. Bot. Mus. Utrecht 285: 1-440.

Chazelles de Prizy, L. M. 1790: Supplement au Dictionaire des Jardiniers, 2. - Metz.

Corti, R. 1938: Le raccolte botaniche nel sud Cirenaico del Prof. L. Di Caporiacco (1933 - Spediz. Marchesi) e del Prof. U. Mónterin (1934 - R. Soc. Geogr. Italiana) e la Florula delle Oasi di Cufra e del Gebél Auenát. - Nuovo Giorn. Bot. Ital., n. s., 45: CCII-CCXLI.

-1942: Flora e Vegetazione del Fezzan e della Regione di Gat. - Reale Soc- Geogr- Ital. 1: 1-272. Cuccuini, P. \& Nepi, C., Abuhadra, M. N., Cecchi, L., Freitag, H., Luccioli, E., Maier Stolte, M., Marcucci, R., Peruzzi, L., Pignotti, L., Stinca, A., Wallnofer, B. \& Wood J. 2015: The Libyan Collections in FI (Herbarium Centrale Italicum and Webb Herbarium) and Studies on the Libyan Flora by R. Pampanini - Part 1. - Bocconea 27(2): 3-132. doi: 10.7320/Bocc27.1.001

De Wilde-Duyfjes, B. E. E. 1976: A revision of the genus Allium (Liliaceae) in Africa. - Meded Landbouwhogeschool Wageningen 76-11: 1-239.

Dobignard, A. \& Chatelain, C. 2010: Index synonimique de la flora d'Afrique du nord, 1. - Genève.

— \& - 2011a: Index synonimique de la flora d'Afrique du nord, 2. - Genève.

— \& - 2011b: Index synonimique de la flora d'Afrique du nord, 3. - Genève.

— \& - 2012: Index synonimique de la flora d'Afrique du nord, 4. - Genève.

— \& - 2013: Index synonimique de la flora d'Afrique du nord, 5. - Genève. 
Domina, G. 2011: Plumbaginaceae - P. 131 in: Greuter, W. \& Raab-Straube, E. von (eds): Euro + Med Notulae 5 [Notulae ad floram euro-mediterraneam pertinentes 27] - Willdenowia 41(1): 129-138. doi: 10.3372/wi.41.41117

Durand, E. \& Barratte, G. 1910: Florae libycae prodromus. - Genève.

Edmonds, J. M. \& Chweya, J. A. 1997: Black nightshades. Solanum nigrum L. and related species. Promoting the conservation and use of underutilized and neglected crops, 15. - Rome.

El Hadidi, M. N. 1972: The Family Zygophyllaceae in Egypt. I Fagonia L. and Seetzenia R. Br. Bot. Not. 125(4): 523-535.

- 1974: Weire Beobachtungen, An Der Gattung Fagonia L. - Mitt. Bot. München 11: 379-404.

Engler, A. 1921: Die Pflanzenwelt Afrikas, insbesondere seiner tropischen Gebiete 3 (2) in: Engler, A. \& Drude, O., Die Vegetation der Erde, 9. - Leipzig.

Feinbrun-Dothan, N. 1978: Flora Palaestina, 3. - Jerusalem.

Ghafoor, A. 1977: Zygophyllaceae. - Pp. 1-55 in: Jafri, S. M. H. \& El Gadi, A. (eds.), Flora of Libya, 38. - Tripoli.

Hilu, K. W. \& Alice, L. A. 2001: A Phylogeny of Chloridoideae (Poaceae) based on matK Sequences. - Syst. Bot. 26(2): 386-405.

Jafri, S. M. H. 1977a: Hypecoaceae. - Pp. 1-9 in: Jafri, S. M. H. \& El Gadi, A. (eds.), Flora of Libya, 44. - Tripoli.

— 1977b: Papaveraceae. - Pp. 1-23 in: Jafri, S. M. H. \& El Gadi, A. (eds.), Flora of Libya, 40. Tripoli.

— 1977c: Rhamnaceae. - Pp. 1-13 in: Jafri, S. M. H. \& El Gadi A. (eds.), Flora of Libya, 30. Tripoli.

— 1977d: Santalaceae. - Pp. 1-4 in: Ali, S. I. \& Jafri, S. M. H. (eds.), Flora of Libya, 14. - Tripoli.

- 1977e: Violaceae. - Pp. 1-4 in: Ali, S. I. \& Jafri, S. M. H. (eds.), Flora of Libya, 13. - Tripoli.

- 1978: Orobanchaceae. - Pp. 1-41 in: Jafri, S. M. H. \& El Gadi, A. (eds.), Flora of Libya, 55. Tripoli.

— 1979: Rubiaceae. - Pp. 1-41 in: Jafri, S. M. H. \& El Gadi, A. (eds.), Flora of Libya, 69. - Tripoli.

— 1984a: Najadaceae. - Pp. 1-4 in: Jafri, S. M. H. \& El Gadi, A. (eds.), Flora of Libya, 113. Tripoli.

— 1984b: Potamogetonaceae. - Pp. 1-12 in: Jafri, S. M. H. \& El Gadi, A. (eds.), Flora of Libya, 114. - Tripoli.

Kadereit, J. W. 1988: A revision of Papaver sect. Rhoedium. - Notes Roy. Bot. Gard. Edinb. 45: 225-286. Lebrun, J.-P. \& Stork, A. L. 1978: Index General des “Contributions a l'Etude de la Flore de 1'Afrique Du Nord" du Dr. René Maire. - Etude Bot. 51-365.

Maire, R. \& al. 1952-1987: Flore de l'Afrique du Nord, 1-16. - Paris.

— \& Weiller, M. 1939: Contributions à l'étude de la flore de L'Afrique du Nord. (fascicule 27). Contributions à l'ètude de la Flore de la Libya. - Bull. Soc. Hist. Nat. Afr. Nord. 30(4-5): 255-314.

McNeill, J., Barrie, F. R., Buck, W. R., Demoulin, V., Greuter, W., Hawksworth, D. L., Herendeen, P. S., Knapp, S., Marhold, K., Prado, J., Prud'homme Van Reine, W. F., Smith, G. F., Wiersema, J. H. \& Turland, N. J. 2012: International Code of Nomenclature for algae, fungi and plants (Melbourne Code). - Regnum vegetabile, 154: 1-140.

Monasterio-Huelin, E. \& Weber, H. E. 1996: Taxonomy and nomenclature of Rubus ulmifolius and Rubus sanctus (Rosaceae). Edinburgh J. Bot. 53(3): 311-322.

Pampanini, R. 1912: Un manipolo di piante della Cirenaica. - Bull. Soc. Bot. Ital. 1912: 115-123.

- 1914a: Piante nuove della Tripolitania settentrionale. - Bull. Soc. Bot. Ital. (1-3): 10-19..

— 1914b: L'Euphorbia bivonae Steud. e il Brachypodium distachyum R. \& S. - Bull. Soc. Bot. Ital. 5: 44-50.

- 1914c: Plantae Tripolitanae ab auctore anno 1913 lectae et repertorium Florae Vascularis Tripolitanae. - Firenze. 
- 1917: Piante di Bengasi e del suo territorio raccolte dal Rev.P. V. D. Zanon della Missione dei P.

P. Giuseppini al Fuehat. II. - Nuovo Giorn. Bot. Ital., n. s., 24: 113-171.

- 1920: Alcune piante della Libia. - Bull. Soc. Bot. Ital. 1920: 17-20.

- 1924: Nuovo contributo alla conoscenza della flora della Cirenaica. - Nuovo Giorn. Bot. Ital. 31 : 193-233.

- 1925: La Libyella cyrenaica (Dur. \& Barr.) Pamp., nuovo genere di Graminacea ed un suo curioso adattamento. - Bull. Soc. Bot. Ital. 1925: 149-57.

- 1926: Le prime notizie sulla vegetazione di Giarabub. - Agric. Colon. 20(12): 455-460.

- 1927: Un nuovo genere di Graminacea ed un suo curioso adattamento "La Libyella cyrenaica

(Dur. \& Barr.) Pamp. - Lybia, 3(1): 68-74.

- 1928: Le raccolte botaniche del Prof. Krueger a Bardia (Marmarica) ed a Giarabub nel 1927 e nella Sirtica orientale ed a Gialo nel 1928. - Agric. Colon. 22(10): 361-368.

- 1930: Prodromo della Flora Cirenaica. - Forlì.

- 1933: La vegetazione spontanea della Cirenaica. - Rend. Sem. Sci. R. Univ. Cagliari 3: 157-158.

- 1936: Aggiunte e correzioni al "Prodromo della Flora Cirenaica". - Arch. Bot. 12: 17-53.

- 1938: Aggiunte al "Prodromo della Flora Cirenaica" delle mie raccolte in Cirenaica negli anni 1933-34. - Sem. Fac. Sci. Univ. Cagliari 8(3): 53-79.

— \& Zanon, V. 1919a: Nuovi contributi alla conoscenza della flora della Cirenaica. - Nuovo Giorn. Bot. Ital., n. s., 26(3): 205-220.

—\& Zodda, G 1932: Un'escursione in Tripolitania. - Arch. Bot. Sist. 8: 97-117.

Petersen, G., Seberg O., Y. de, M. \& Berthelsen, K. 2006: Phylogenetic relationships of Triticum and Aegilops and evidence for the origin of the A, B and D genomes of common wheat (Triticum aestivum) - Molec. Phylogen. Evol. 39: 70-82.

Peterson, P. M., Romaschenko K., Snow, N. \& Johnson, G. 2012: A molecular phylogeny and classification of Leptochloa (Poaceae: Chloridoideae: Chlorideae) sensu lato and related genera. - Ann. Bot. (Oxford) 109: 1317-1329.

Pignatti, S. 1963: Uber die beziehungen italienischen und iberischen Arten der Gattung Limonium (Plumbaginaceae). - Webbia 18: 73-93

Post, G. E. 1932-33: Flora of Syria, Palestine and Sinai, 1-2. - Beirut.

Quézel, P. 1978: Analysis of the Flora of Mediterranean and Saharan Africa. - Ann. Missouri Bot. Gard. 65: 479-534.

Qaiser, M. 1982: Scrophulariaceae. - Pp. 1-70 in: Jafri, S. M. H. \& El Gadi, A. (eds.), Flora of Libya, 88. - Tripoli.

— 1984: Ranunculaceae. - Pp. 1-54 in: Jafri, S. M. H. \& El Gadi, A. (eds.), Flora of Libya, 108. Tripoli.

— \& Ghafoor, A. 1979: Tamaricaceae. - Pp. 1-25 in: Jafri, S. M. H. \& El Gadi, A. (eds.), Flora of Libya, 66. - Tripoli.

Richardson, I. B. K. 1975: A revision of genus Centranthus DC. (Valerianaceae). - Bot. J. Linn. Soc. 71(3): 211-234.

Sandve, S. R., Marcussen, T., Mayer, K., Jacobsen, K. S., Heier, L., Steuernagel, B., Wulff, B. B. H. \& Olsen, O. A. 2015: Chloroplast Phylogeny of Triticum/Aegilops species is not incongruent with an ancient homoploid hybrid origin of the ancestor of the bread wheat D-genome - New Phytol. 208(1): 9-10.

Scholz, H. 1974a: Bromus chrysopogon Viviani - eine wider als Art Graminee aus dem Mittelmeergebiet. - Willdenowia 7(2): 409-413.

-1974b: Liste der Graser Libyens. - Willdenowia 7(2): 419-458.

- 1981: Drei neue Gramineen aus Iran und Libyen - Willdenowia 11(1): 95-100.

Siddiqi, M. A. 1978: Solanaceae. - Pp. 1-38 in: Jafri, S. M. H. \& El Gadi, A. (eds.), Flora of Libya, 62. - Tripoli. 
— 1979: Plantaginaceae. - Pp. 1-29 in: Jafri, S. M. H. \& El Gadi, A. (eds.), Flora of Libya, 67. Tripoli.

— \& Sherif, A. S. 1988: Poaceae. - Pp. 1-336 in: El Gadi, A. A. (ed.), Flora of Libya, 145. - Tripoli. Soreng, R. J., Peterson, P. M., Romaschenko, K., Davidse, G., Zuloaga, F. O., Judziewicz, E. J., Filgueiras, T. S., Davis, J. I. \& Morrone, O. 2015: A worldwide phylogenetic classification of the Poaceae (Gramineae) - J. Syst. Evol. 53(2): 117-137. doi: 10.1111/jse.12150.

Steinberg, C. H. 1981: Nomenklatorische Typen aus der Gattung Bromus in italianischen Herbarien. - Bot. Jahrb. Syst. 102 (1-4): 411-425.

Sudre, H. 1908-1913: Rubi Europae, vel monographia iconibus illustrata ruborum Europae. - Paris.

Sutton, D. A. 1988: A revision of the tribe of Antirrhineae. - London \& Oxford.

Thiers, B. [continuously updated]. Index Herbariorum: A global directory of public herbaria and associated staff. New York Botanical Garden's Virtual Herbarium. http://sweetgum.nybg.org/science/ih/. [accessed: 30.06.2016].

Triest, L. 1987: A revision of the genus Najas L. (Najadaceae) in Africa and surrounding islands. Mém. Acad. Roy. Sci. Outre-Mer, Cl. Sci. Nat. Méd. Collect., n.s., 21(4): 5-88.

Valdés, B. \& Scholz, H. (with contributions from Raab-Straube, E. von \& Parolly, G.) 2009: Poaceae (pro parte majore). Euro+Med Plantbase - the information resource for Euro-Mediterranean plant diversity, http://ww2.bgbm.org/EuroPlusMed/query.asp, [accessed 03.06.2016].

Vegter, I. H. 1983: Index Herbariorum II(5) Collectors N-R. - Regnum Vegetabile 109: 1-803

Viano, J. 1978a: Les linaires à graines aptères du bassin méditerranéen occidental. 1. Linaria sect. Versicolores. - Candollea 33(1): 43-88.

- 1978b: Les linaires à graines aptères du bassin méditerranéen occidental. 1. Linaria sect. Elegantes, Bipunctatae, Diffusae, Repentes. - Candollea 33(2): 209-267.

Viviani, D. 1824: Florae libycae specimen. - Genuae.

Wang, Wen-Tsai 2003: Revisio of Clematis sect. Clematis (Ranunculaceae) (Continued). - Acta Phytotaxon. Sinica 41(2): 97-172.

Wickens, G. E. 1975: A revision of the (Kickxia aegyptiaca) complex (Scrophulariaceae). - Kew Bull. 30(1): 11-15.

Wood, J. R. I., Williams, B. R. M., Mitchell, T. C., Carine, M. A., Harris, D. J. \& Scotland, R. W. 2015: A foundation monograph of Convolvulus L. (Convolvulaceae). - PhytoKeys 51: 1: 282. doi $10.3897 /$ phytokeys.51.7104

\section{Maps consulted}

Istituto Geografico Militare 1923: Carta del territorio della Tripolitania (scala $1: 400.000$ ). - Firenze.

- 1911: Carta dimostrativa della Cirenaica (scala $1: 600.000$ ). - Firenze.

Touring Club Italiano 1922: Guida della Libia - Cirenaica e regioni adiacenti ${ }^{\circ}$ 639bis (scala 1 : 1.500.000). - Milano.

— 1922: Guida della Libia - Tripolitania Settentrionale ${ }^{\circ}$ 635bis (scala1 : 1.500.000). - Milano.

\section{Unpublished sources}

Registro degli aumenti (1841-1938)

“ " (1939-1977)

“ $\quad "(1978-2005)$

“ $\quad "(2005-\ldots$.

Indici scambi (nos 1-70)

Indici scambi (nos. 71-126)

Raccolte Cirenaiche dei Proff. R. Pampanini e R.E.G. Pichi Semolli (Serie duplicate (1933-1934)

Registro arrivi e spedizioni piante (1949-1970) 


\section{Addenda et Corrigenda}

The data on the following list were either omitted (as they were unknown at the time), erroneously or only partially illustrated or mentioned in the $1^{\text {st }}$ part of this work (Cuccuini \& al. 2015).

\section{Addenda}

In "Phytogeographical placing of collection areas" pag. 23.

In figure 5, with regard to the area of Pampanini's collections of 1933, the part between Bardiya and Scegga is missing. Moreover we added the collection locality of De Cillis near Barce, limited to material considered in Cuccuini \& al. (2015).

\section{Alliaceae}

New taxon: Allium greuteri Brullo \& Pavone in Willdenowia 13(1): 115. 1983.

Type: [Libya], Cirenaica: Wadi el Bab, 16/05/1981. Leg. Brullo S. \& Furnari by Brullo \& Pavone in Willdenowia 13(1): 115. 1983, Isotypus in (B, CAT, FI),

Holotypus (CAT)

Accepted name: Allium greuteri Brullo \& Pavone see Dobignard \& Chatelain 1: 65. 2010.

\section{Asteraceae}

New taxon Atractylis prolifera Boiss. var. albiflora Cavara (sub Atractylis prolifera) in Bullettino dell'Orto Botanico R. Università di Napoli 9(1): 51 (1928); nomen nudum.

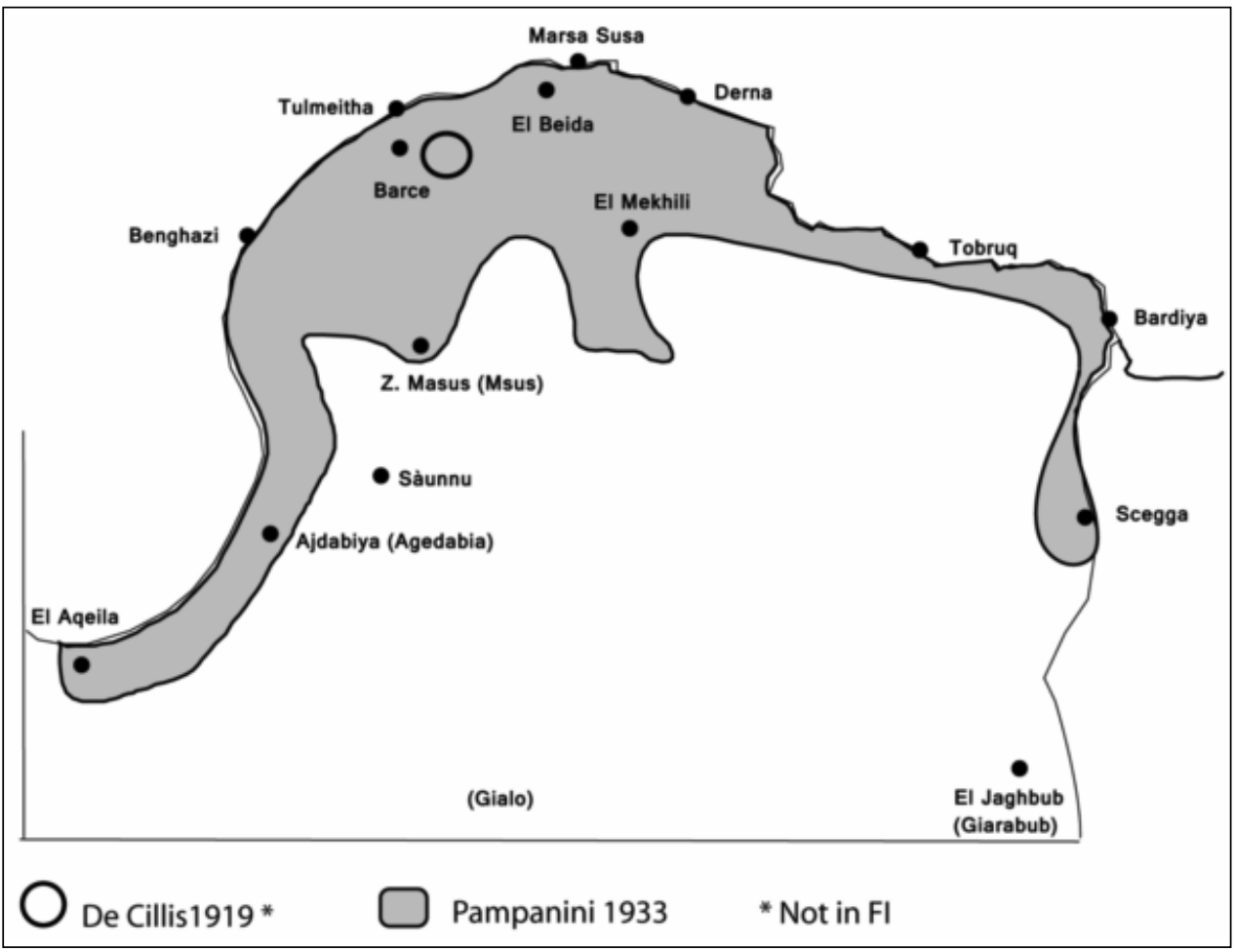

Corrige Fig. 1. Collections by De Cillis in 1919 and Pampanini's in 1933. 
Original material: [Libia], Cyrenaica: steppa a sud di Agedabia, 25/04/1925. Leg. F. Cavara (FI).

New taxon Onopordum cyrenaicum Maire \& Weiller in Bull. Soc. Hist. Nat. Afr. Nord. 30 (4-5). 285. 1939.

Type: Lectotypus: Lybie, Cyrenaique: Uadi Derna (901), punti(e)s picneuses, 25/04/1938. Leg. R. Maire \& M. Weiller. (FI) (Designated (as typus) by S. A. Alavi in Fl. Lib. 107: 246.1983).

Isolectotypus MPU

Accepted name: Onopordum cyrenaicum Maire \& Weiller, see Dobignard \& Chatelain 2: 330. 2011a; also in Fl. Lib. 107: 245-46. 1983.

Note: the specimen kept in FI is marked as Holotypus by P. Hein 2002; a $2^{\text {nd }}$ syntypus is held in MPU. The transcripton of the labels of both specimens (MPU and FI) slightly differs from the texts published in Maire \& Weiller (1939).

\section{Illecebraceae}

(In Dobignard \& Chatelain (2011b) in Caryophyllaceae)

New taxon: Paronychia arabica subsp. tibestica var. fezzanica Chaudri [sub. P. arabica subsp. desertorum (Boiss.) Batt.] in Chaudri: A revision of Paronychiinae.- Meded. Bot. Mus. Utrecht 285: 208. 1933. Utrecth.

Type: Holotypus: [Libya]: Fezzan sett., Wadi Zigza, ca $400 \mathrm{~m}$. sul fondo pietroso sabbioso, (1196), 15/04/1933. Leg. R. Corti (FI). By Chaudri in: Chaudri 285: 209. 1968

Accepted name: Paronychia arabica subsp. tibestica var. fezzanica Chaudri, by Chaudri in Chaudri 285: 209. 1968

Note: as P. arabica subsp. tibestica Quézel in Dobignard \& Chatelain 3: 223. 2011 b.

In our opinion, the morphological differences observed by Chaudri (1968) and by us confirm his taxonomic decision in the subsp. tibestica Quézel group, regarding the autonomic var. and var. fezzanica. This is also considering the investigation the Pakistan scholar managed to perform on all the mountain material from Tibesti, among other things very far from Tibesti itself, including Chad. Therefore we recognise the validity of the proposition Chaudri put forward regarding var. fezzanica.

\section{Corrigenda}

-Pag. 32:

\section{Alliaceae}

In Cuccuini \& al. 2015 Pampanini's specimen 1349 of Allium aschersonianum f. laeve Pamp. was erroneously indicated as Holotypus following B.E.E. de Wilde-Duyfjes (1976), nevertheless this author cited some other syntypi.

New taxon: Allium aschersonianum f. laeve Pamp. in Arch. Bot. (Forli) XII(1): 21. (1936a); Rend. Sem. Fac. Sc. Univ. Cagliari VIII(3): 63 (1938).

Type: Libia, Cirenaica, [Marmarica]: Tobruk (1349), 23/3/1933. Leg. R. Pampanini, (FI003619, Lectotypus designated here)

-Pag. 34

Apiaceae

In the 1st part of this work (Cuccuini \& al. 2015), typification of Pachyctenium mirabile Pampanini \& Maire on page 34 is partially in error as only one plant of specimen n. 5637 (the one top right on the sheet) was designated as lectotypus for the reasons explained in the note. But after a more careful reading of Art. 8.2 of the ICN (McNeill \& al. 2012) that defines the meaning of "specimen", i.e. intended "as gathering, or part of a gathering of a single species or infraspecific taxon made at one time.." we decided to choose the whole of specimen no. 5637 as Lectotypus for this name. Therefore the designation of the previous Lectotypus as well as identification of the Isolectotypus on the same sheet should be considered ineffective. 
Type: Libya, Cyrenaica, El Beda: Uadi Beregd (5637), 27/04/1934. Leg. R. Pampanini \& R.E.G. Pichi Sermolli. (FI). (Lectotypus designated here)

Consequenly the legend for Fig. 9 on page 37 should read:

Specimen no. 5637, collected by R. Pampanini in Libya in 1933 and consisting of the plant $P$. mirabile Maire \& Pamp. photographed in Arch. Bot. 12(2). 1936 (top right on sheet), is the Lectotypus of the taxon.

There are several misprints and illegible parts in Cuccuini \& al. (2015) ; (not enclosed in taxonomic index).

-Pag. 22

In List of Collectors

corrige

Longa A.: Cyr.

-Pag. 48

in Cladanthus arabicus var. pygmaeus Pamp.

corrige

Type: $.22 / 04 / 1913$

-Pag. 53

In Launaea resedifolia var pulchella Pamp.

corrige

Other material: [L., C.,], Sirtica orientale: Maatan Risam: Gasr es Sahabi, 18/04/1928. Leg. G. Krueger, (FI003567). This specimen is not cited in the Protologue.

The "Note"paragraph is deleted.

-Pag. 64

In Silene setacea var. glabrescens Pamp.

corrige

Type. el Acheim-Acroma

-Pag. 85

In Trigonella stellata var. micrantha Pamp

corrige

Syntypi.........4191(FI003427); 4187 [signed twice]

—Pag. 109

The Lavatera genus is at page: 109

corrige

Lavatera brioniifolia Mill. * 100,101

Lavatera olbia subsp. cyrenaica Pamp. 100

Lavatera olbia subsp. cyrenaica var. vestita Pamp. 100

-Pag 131

In Reference

After 'Rosuà 1986' all publications attributed to him are actually P.A. Saccardo's. corrige

Rosùa, J.- L. 1986: Contribucion al Estudio del Genero Rosmarinus L. en el Mediterraneo occidental. - Lagascalia 14(2): 179-187.

Saccardo, P. A. 1913a: Fungi tripolini a R. Pampanini anno 1913 lecti. - Bull. Soc. Bot. Ital. 1913: 150-156.

- 1913b: Fungi Tripolitani. Notae mycologicae, ser XVIII(3). - Ann. Mycol., 12.

— 1913c: Fungi Tripolitani. Notae mycologicae, ser XVII(7). - Ann. Mycol., 11. 

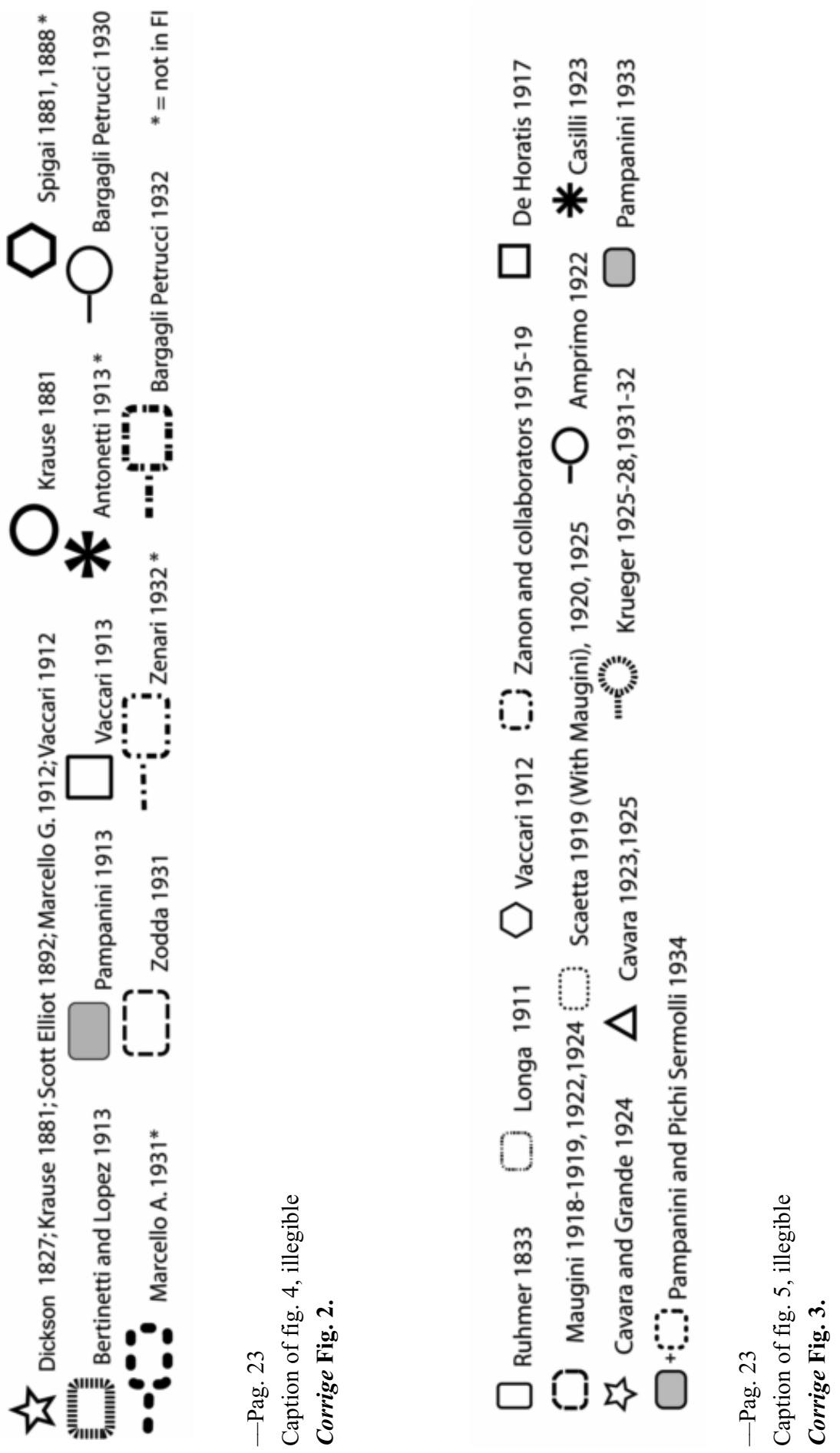
- 1917: Fungi. - Pp. 113-171 in: Pampanini, R., Piante di Bengasi e del suo territorio raccolte dal Rev. P. V. D. Vito Zanon della Missione dei P. P. Giuseppini al Fuehat. II. - Nuovo Giorn. Bot. Ital., n. s., 24: 113-171.

- 1919: Fungi. - Pp. 218-219 in: Pampanini, R. \& Zanon, V., Nuovi contributi alla conoscenza della flora della Cirenaica. - Nuovo Giorn. Bot. Ital., n. s., 26: 205-220.

\section{Convolvulaceae}

In the first part of this work (Cuccuini \& al. 2015), the material for the genus Convolvulus, so competently and scientifically considered by J.R.I. Wood, was published (along with some typifications). However, we were entirely unaware of the date of Wood's publication (see Wood \& al. 2015), and did not see a copy of his article until after our own was published. Wood \& al. (2015) pre-dates the first part of our work, and this has led to an unfortunate situation with overlaps in coverage, and changes in the bibliographical priority of some typifications.

\section{Addresses of the authors:}

Piero Cuccuini ${ }^{1}$, Chiara Nepi ${ }^{1}$, Mohamed N. Abuhadra ${ }^{2}$, Enrico Banfi ${ }^{3}$, Gianniantonio Domina ${ }^{4}$, Egildo Luccioli ${ }^{1}$, Stefano Miranda ${ }^{1}$, Konrad Pagitz ${ }^{5}$, Mike Thiv $^{6}$, Errol Vela ${ }^{7}$,

${ }^{1}$ Piero Cuccuini, Chiara Nepi, Egildo Luccioli, Stefano Miranda Museo di Storia Naturale di Firenze - Sez. di Botanica, Università di Firenze, Via G. La Pira 4, 50125 Firenze, Italy, piero.cuccuini@unifi.it, chiara.nepi@unifi.it, egildo.luccioli@unifi.it, vanyarhon@gmail.com

${ }^{2}$ Mohamed N. Abuhadra, Faculty of Science and Libyan National Herbarium (ULT), Tripoli University P.O. Box 13211 Tripoli - Libya abuhadra2001@gmail.com

${ }^{3}$ Enrico Banfi, via Viminale 7, I-20131 Milano, Italy, enrbanfi@yahoo.it

${ }^{4}$ Gianniantonio Domina, Department of Agricultural and Forest Sciences, University of Palermo, via Archirafi 38. 90123 Palermo, Italy. E-mail: gianniantonio.domina@unipa.it

${ }^{5}$ Konrad Pagitz, Institute of Botany University of Innsbruck, Sternwartestraße 15 6020 Innsbruck, Austria Konrad.Pagitz@uibk.ac.at

${ }^{6}$ Mike Thiv, Keeper Botany Dept / Curator Herbarium STU, Staatliches Museum für Naturkunde Stuttgart, Rosenstein 1, D-70191 Stuttgart, Germany, mike.thiv@,smnsbw.de

${ }^{7}$ Errol Vela, University of Montpellier, UMR AMAP, CIRAD, TAA51/PS2, 34398 Montpellier cedex 5, France, errol.vela@cirad.fr 
